\title{
ॠUSGS
}

science for a changing world

Borehole-Explosion and Air-Gun Data Acquired in the 2011 Salton Seismic Imaging Project (SSIP), Southern California: Description of the Survey

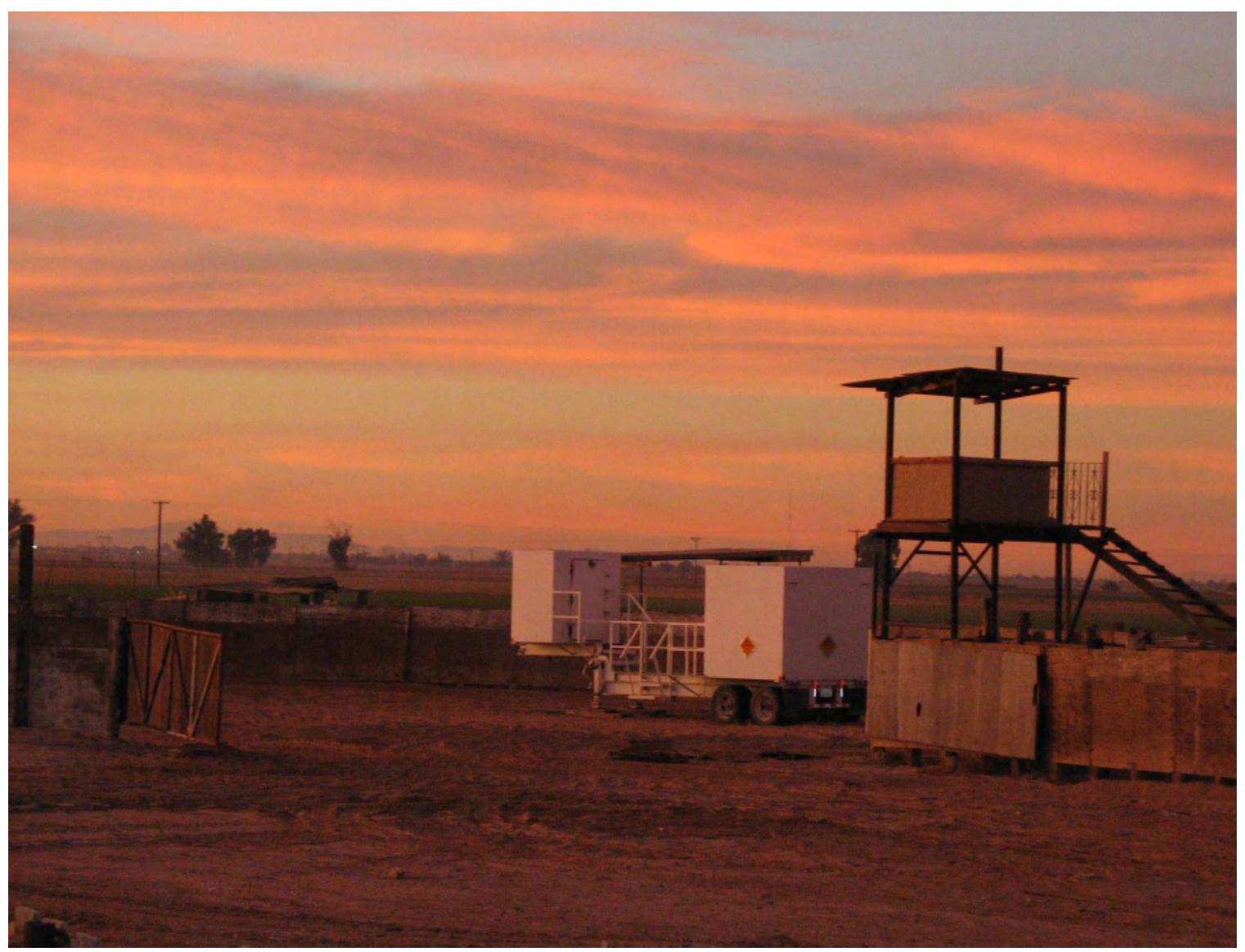

Open-File Report 2013-1172

U.S. Department of the Interior

U.S. Geological Survey 
COVER:

High-explosives magazine, used for the Salton Seismic Imaging Program, parked in secured, unused private rodeo ground in Imperial Valley, California. Photo by Gary Fuis. 


\section{Borehole-Explosion and Air-Gun Data Acquired in the 2011 Salton Seismic Imaging Project (SSIP), Southern California: Description of the Survey}

By Elizabeth J. Rose, Gary S. Fuis, Joann M. Stock, John A. Hole, Annie M. Kell, Graham Kent, Neal W. Driscoll, Sam Crum, Mark Goldman, Angela M. Reusch, Liang Han, Robert R. Sickler, Rufus D. Catchings, Michael J. Rymer, Coyn J. Criley, Daniel S. Scheirer, Steven M. Skinner, Coye J. Slayday-Criley, Janice M. Murphy, Edward G. Jensen, Robert McClearn, Alex J. Ferguson, Lesley A. Butcher, Max A. Gardner, lain Emmons, Caleb L. Loughran, Joseph R. Svitek, Patrick C. Bastien, Joseph A. Cotton, David S. Croker, Alistair J. Harding, Jeffrey M. Babcock, Steven H. Harder, and Carla M. Rosa

Open-File Report 2013-1172

U.S. Department of the Interior U.S. Geological Survey 


\title{
U.S. Department of the Interior \\ SALLY JEWELL, Secretary
}

\section{U.S. Geological Survey \\ Suzette M. Kimball, Acting Director}

U.S. Geological Survey, Reston, Virginia: 2013

For more information on the USGS-the Federal source for science about the Earth, its natural and living resources, natural hazards, and the environment-visit http://www.usgs.gov or call 1-888-ASK-USGS

For an overview of USGS information products, including maps, imagery, and publications, visit $h$ ttp://www.usgs.gov/pubprod

To order this and other USGS information products, visit http://store.usgs.gov

\begin{abstract}
Suggested citation:
Rose, E.J., Fuis, G.S., Stock, J.M., Hole, J.A., Kell, A.M., Kent, G., Driscoll, N.W., Crum, S., Goldman, M., Reusch, A.M., Han, L., Sickler, R.R., Catchings, R.D., Rymer, M.J., Criley, C.J., Scheirer, D.S., Skinner, S.M., Slayday-Criley, C.J., Murphy, J.M., Jensen, E.G., McClearn, R., Ferguson, A.J., Butcher, L.A., Gardner, M.A., Emmons, I., Loughran, C.L., Svitek, J.R., Bastien, P.C., Cotton, J.A., Croker, D.S., Harding, A.J., Babcock, J.M., Harder, S.H., and C.M. Rosa, 2013, Borehole-explosion and air-gun data acquired in the 2011 Salton Seismic Imaging Project (SSIP), southern California-Description of the survey: U.S. Geological Survey Open-File Report 2013-1172, 84 p., http://dx.doi.org/10.3133/ofr20131172.
\end{abstract}

Any use of trade, product, or firm names is for descriptive purposes only and does not imply endorsement by the U.S. Government.

Although this report is in the public domain, permission must be secured from the individual copyright owners to reproduce any copyrighted material contained within this report. 


\section{Contents}

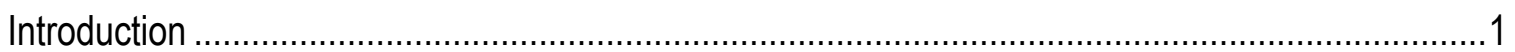

Geological and Geophysical Setting ...............................................................................

Questions to be Addressed by the Salton Seismic Imaging Project...........................................10

Prior Crustal-Structure Work ................................................................................................11

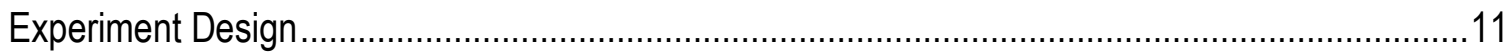

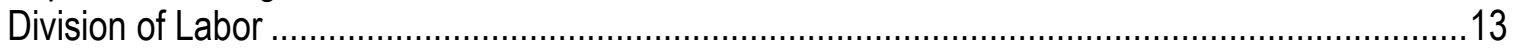

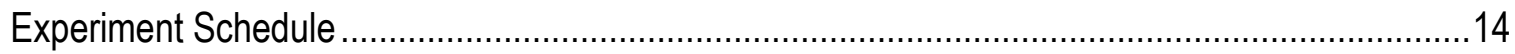

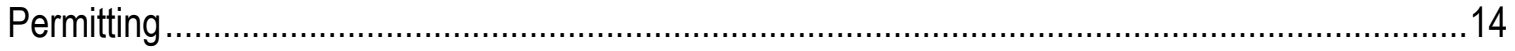

Land Shot Size Determination..........................................................................................16

Land Shot Drilling, Loading, and Shooting ......................................................................18

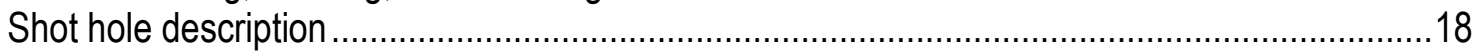

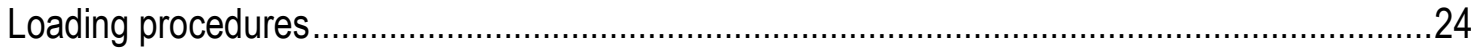

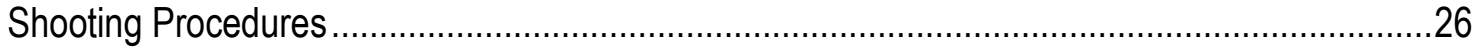

Land Seismometer Deployment....................................................................................4

Line Scouting, Surveying, Staking, Logging ..................................................................4

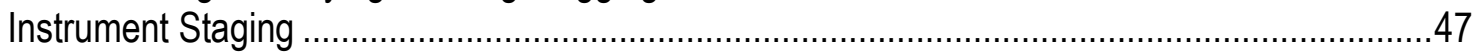

Field Personnel and Training for Instrument Deployment and Pickup ...................................50

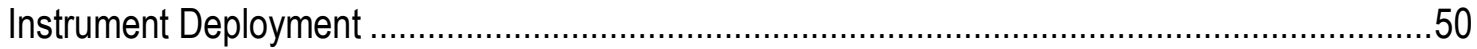

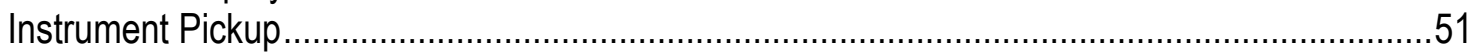

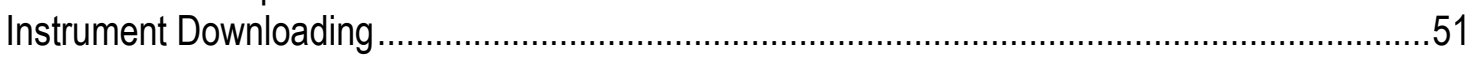

Data Processing (Cutting of Record Sections) …………................................................52

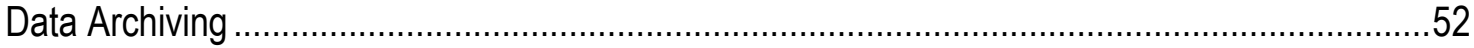

Salton Sea Ocean-Bottom Seismometer Deployment and Air-Gun Operations.............................55

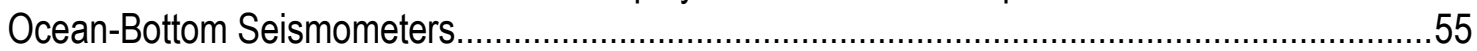

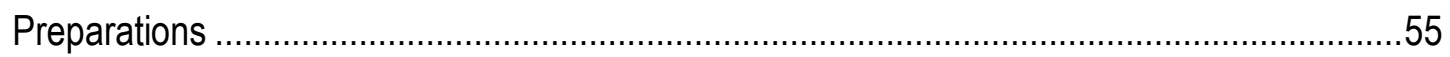

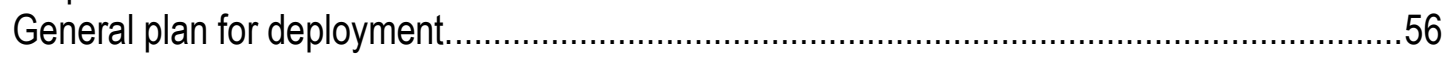

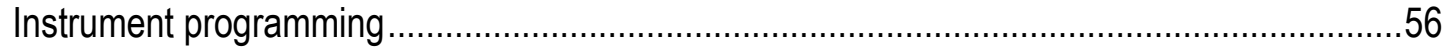

Instrument deployment ……..............................................................................

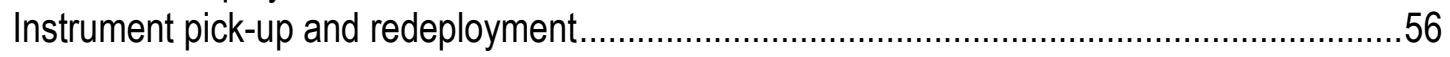

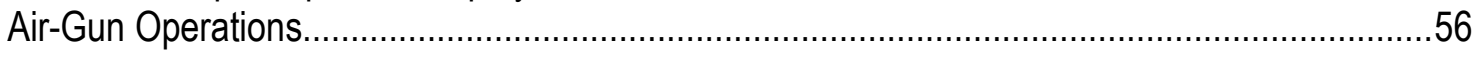

General Plan for Air-Gun Tracks..................................................................................56

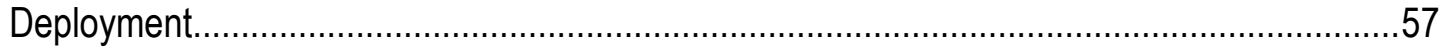

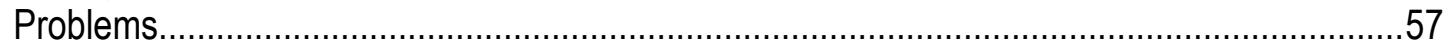

Seismic Acquisition Systems.........................................................................................57

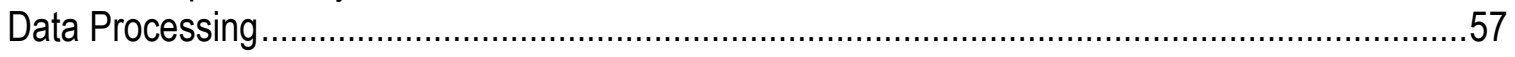

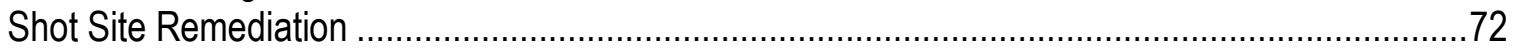

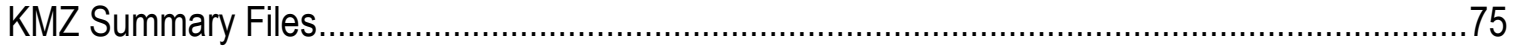

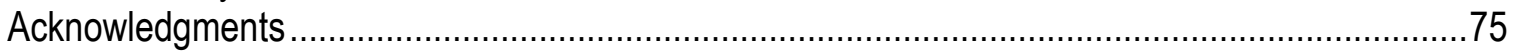

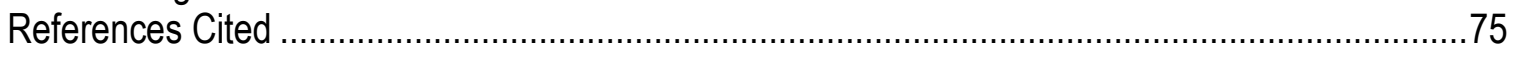

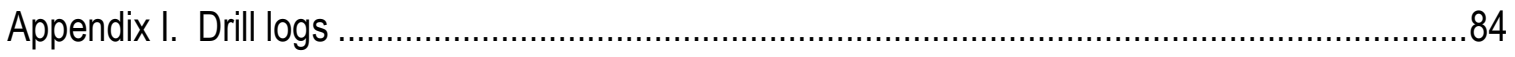

Appendix II. Drill sample inventory ...................................................................................84

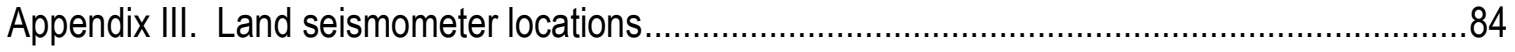

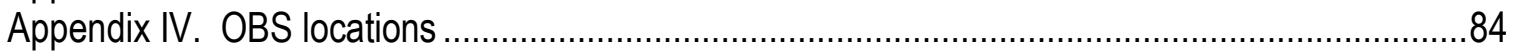

Appendix V. Air gun shot times and locations (complete list) ..................................................84 
Appendix VI. Data supplied to PIs by IRIS ………………....................................................84

Appendix VII. SSIP KMZ files (for use in Google Earth ${ }^{T M}$ ) ...................................................84

Appendix VIII. Full datasets for tables 1-10 .....................................................................84

\section{Figures}

1a. Shaded relief map of southeastern California showing faults, including the boundary between the Pacific and North American Plates and the Salton Buttes volcanoes.

1b. Shaded relief map of southeastern California showing the Salton Seismic Imaging Project...... 4

2. Tectonic map of the Gulf of California and Salton Trough, emphasizing oblique northwest extension accommodated by a series of pull-apart basins in step-overs between long strike-slip faults.

3. Map of seismicity and volcanoes in the southern part of the Salton Sea and northern part of

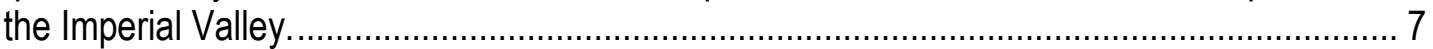

4. Map of southeastern California showing the 1979 and 1992 seismic-imaging projects in the

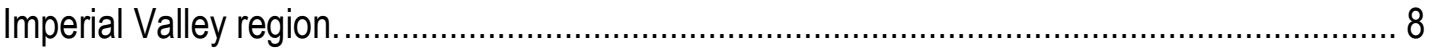

5. Map of southeastern California showing basement depth calculated from time-term

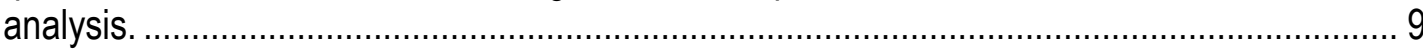

6. Cross-section of southernmost California based on gravity data between San Diego and the

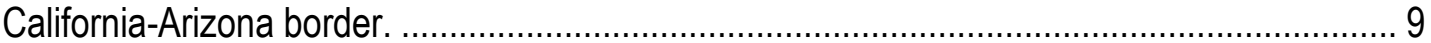

7a. Cross-sectional diagram of shot holes drilled into soft sediment ...........................................19

7b. Cross-sectional diagram of shot holes drilled into hard rock ................................................20

8. Photograph of U.S. Geological Survey personnel loading blasting agent into shot hole

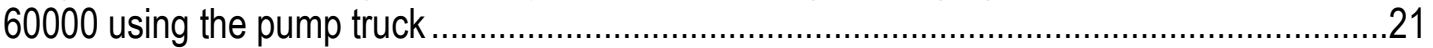

9. Blank drilling log sheet used by drill watchers for the Salton Seismic Imaging Project...............22

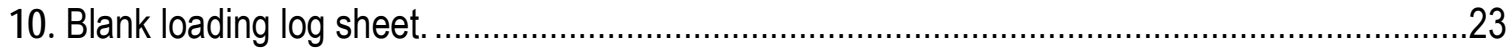

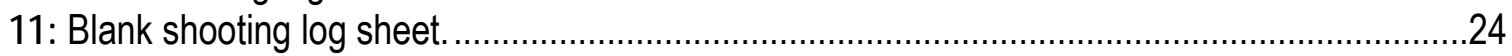

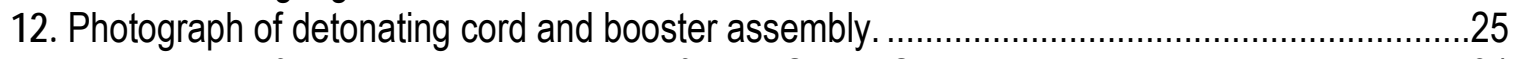

13. Photograph of the shooting system built for the Salton Seismic Imaging Project......................34

14a. Seventeen maps of seismometers, ocean-bottom seismometers, and land shots by Julian day, from days $62-76$.

14b. Six Maps of seismometers, ocean-bottom seismometers, and air-gun shots by Julian day.

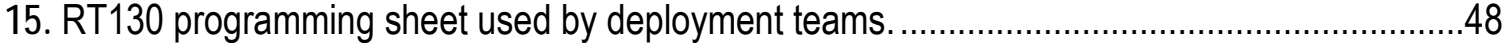

16. Texan deployment and retrieval sheet used by deployment teams ......................................52

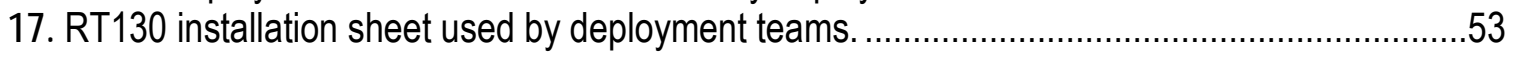

18. RT130 removal sheet used by deployment teams. ............................................................54

19. Photograph of barge constructed on site to accommodate the marine part of the Salton

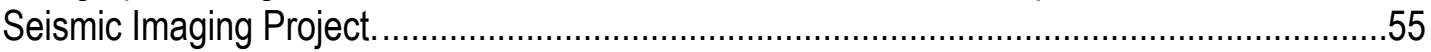

20. Shot gathers (for land shots, land seismometers, and OBSs) and receiver gathers (for airgun shots, OBSs, and land seismometers).

21. Photo of a U.S. Geological Survey crew member "replanting" dead cholla cacti on Bureau of Land Management land along Line 6. 


\section{Tables}

1. Experiment schedule

2. Permitting: Entities Involved.................................................................................15

3. Land shot-hole loading details for 23 shot points. Full data for all shot points from the Salton Seismic Imaging Project are given in appendix VIII........................................................17

4. Land shot times and locations ("shot list") for all shots from the Salton Seismic Imaging

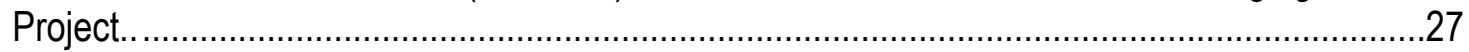

5. Land shot-hole shooting details for 6 shot points. Data for all shot holes are available in

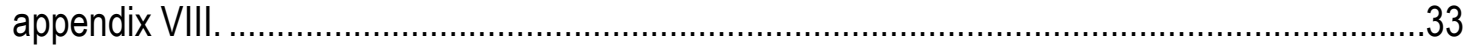

6. Air-gun shot times and locations for 5 shots. Data for all shots are given in appendix VIIII.........48

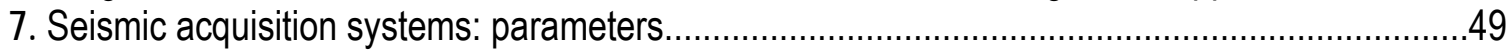

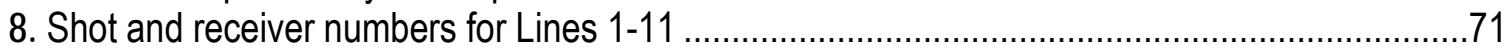

9. Cleanup details for 6 boreholes. Details for all boreholes are available in appendix VIII.............73

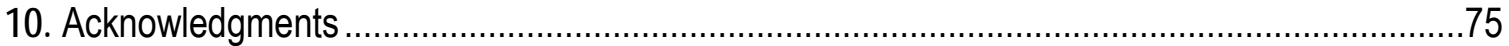


This page intentionally left blank 


\title{
Borehole-Explosion and Air-Gun Data Acquired in the 2011 Salton Seismic Imaging Project (SSIP), Southern California: Description of the Survey
}

\author{
By Elizabeth J. Rose ${ }^{1}$, Gary S. Fuis' ${ }^{1}$, Joann M. Stock ${ }^{2}$, John A. Hole ${ }^{3}$, Annie M. Kell14, Graham \\ Kent', Neal W. Driscolli5, Sam Crum6, Mark Goldman' ${ }^{1}$, Angela M. Reusch 7 , Liang Han ${ }^{3}$, Robert R. \\ Sickler ${ }^{1}$, Rufus D. Catchings ${ }^{1}$, Michael J. Rymer ${ }^{1}$, Coyn J. Criley ${ }^{1}$, Daniel S. Scheirer ${ }^{1}$, Steven M. \\ Skinner ${ }^{2}$, Coye J. Slayday-Criley ${ }^{1}$, Janice M. Murphy ${ }^{1}$, Edward G. Jensen ${ }^{1}$, Robert McClearn ${ }^{1}$, Alex \\ J. Ferguson ${ }^{1}$, Lesley A. Butcher ${ }^{1}$, Max A. Gardner ${ }^{1}$, lain Emmons ${ }^{8}$, Caleb L. Loughran ${ }^{8}$, Joseph R. \\ Svitek', Patrick C. Bastien 7 , Joseph A. Cotton ${ }^{1}$, David S. Croker ${ }^{1}$, Alistair J. Harding ${ }^{5}$, Jeffrey M. \\ Babcock ${ }^{5}$, Steven H. Harder ${ }^{9}$, and Carla M. Rosa ${ }^{1}$
}

\section{Introduction}

The Imperial and Coachella Valleys are being formed by active plate-tectonic processes. From the Imperial Valley southward into the Gulf of California, plate motions are rifting the continent apart. In the Coachella Valley, the plates are sliding past one another along the San Andreas and related faults (fig. 1). These processes build the stunning landscapes of the region, but also produce damaging earthquakes.

Rupture of the southern section of the San Andreas Fault (SAF), from the Coachella Valley to the Mojave Desert, is believed to be the greatest natural hazard that California will face in the near future. With an estimated magnitude between 7.2 and 8.1, such an event would result in violent shaking, loss of life, and disruption of infrastructure (freeways, aqueducts, power, petroleum, and communication lines) that might bring much of southern California to a standstill. As part of the nation's efforts to avert a catastrophe of this magnitude, a number of projects have been undertaken to more fully understand and mitigate the effects of such an event. The Salton Seismic Imaging Project (SSIP), funded jointly by the National Science Foundation (NSF) and the U.S. Geological Survey (USGS), seeks to understand, through seismic imaging, the structure of the Earth surrounding the SAF, including the sedimentary basins on which cities are built.

\footnotetext{
${ }^{1}$ Earthquake Science Center, U.S. Geological Survey, Menlo Park, Calif.

${ }^{2}$ Seismological Laboratory, California Institute of Technology, Pasadena, Calif.

${ }^{3}$ Geosciences, Virginia Polytechnic Institute and State University, Blacksburg, Va.

${ }^{4}$ Nevada Seismological Laboratory, University of Nevada, Reno, Nev.

${ }^{5}$ Scripps Institution of Oceanography, University of California, San Diego, Calif.

${ }^{6}$ Sam Crum Water Well Drilling, Hemet, Calif.

${ }^{7}$ IRIS-PASSCAL Instrument Center, Socorro, N.M.

${ }^{8}$ Southwest Biological Science Center, U.S. Geological Survey, Flagstaff, Ariz.

${ }^{9}$ J.W. Miller Geophysical Laboratory, University of Texas, El Paso, Texas
} 
The principal investigators (PIs) of this collaborative project represent the USGS, Virginia Polytechnic Institute and State University (Virginia Tech), California Institute of Technology (Caltech), Scripps Institution of Oceanography (Scripps), and University of Nevada, Reno (UNR).

SSIP will create images of underground structure and sediments in the Imperial and Coachella Valleys and adjacent mountain ranges to investigate the earthquake hazards posed to cities in this area. Importantly, the images will help determine the underground geometry of the SAF, how deep the sediments are, and how fast earthquake energy can travel through the sediments. All of these factors determine how hard the earth will shake during a major earthquake. If we can improve on our understanding of how and where earthquakes will occur, and how strong their resultant shaking will be, then buildings can be designed or retrofitted accordingly in order to resist damage and collapse, and emergency plans can be adequately prepared. In addition, SSIP will investigate the processes of rifting and magmatism in the Salton Trough in order to better understand this important plate-boundary region. The Salton Trough is a unique rift in that subsidence is accompanied by huge influxes of infilling sediment from the Colorado River. Volcanism that accompanies the subsidence here is muted by these influxes of sediment. The Imperial Valley, in the central part of the Salton Trough, is apparently made up of entirely new crust: young sediment in the upper crust and basaltic intrusive rocks in the mid-to-lower crust (Fuis and others, 1984).

Similar to the ultrasound and computed tomography (CT) scans performed by the medical industry, seismic imaging is a collection of techniques that enable scientists to obtain a picture of what is underground. The petroleum industry routinely uses these techniques to search for oil and gas at relatively shallow depths; however, the scope of this project demanded that we image as much as $30 \mathrm{~km}$ into the earth's crust. This project generated and recorded seismic waves, similar to sound waves, which move downward into the Earth and are bent (refracted) or echoed (reflected) back to the surface.

SSIP acquired data in a series of intersecting lines that cover key areas of the Salton Trough. The sources of sound waves were detonations (shots) in deep boreholes, designed to create energy equivalent to magnitude 1-2 earthquakes. The study region routinely experiences earthquakes of these magnitudes, but earthquakes are not located in such a way as to permit us to create the detailed images we need for earthquake hazard assessment. Air gun bursts, generated in the Salton Sea along extensions of our onshore seismic lines, also were utilized as sound-wave sources. Temporary deployments of portable land seismometers, as well as ocean-bottom seismometers (OBSs) on the floor of the Salton Sea, recorded the energy from the land shots and air gun bursts.

SSIP is similar to the Los Angeles Regional Seismic Experiments of 1994 and 1999 (LARSE I and II, respectively; Murphy and others, 1996; Fuis and others, 2001a). The LARSE surveys demonstrated that the USGS and collaborators can safely and effectively conduct seismic imaging surveys in urban and nonurban areas, on lands owned and/or managed by many different types of agencies and entities. Information was produced that could not have been obtained any other way, and this information was key to changing the leading ideas about earthquake hazards at that time in the Los Angeles region. These surveys produced no significant environmental impact or damage to structures, and they did not trigger earthquakes. 


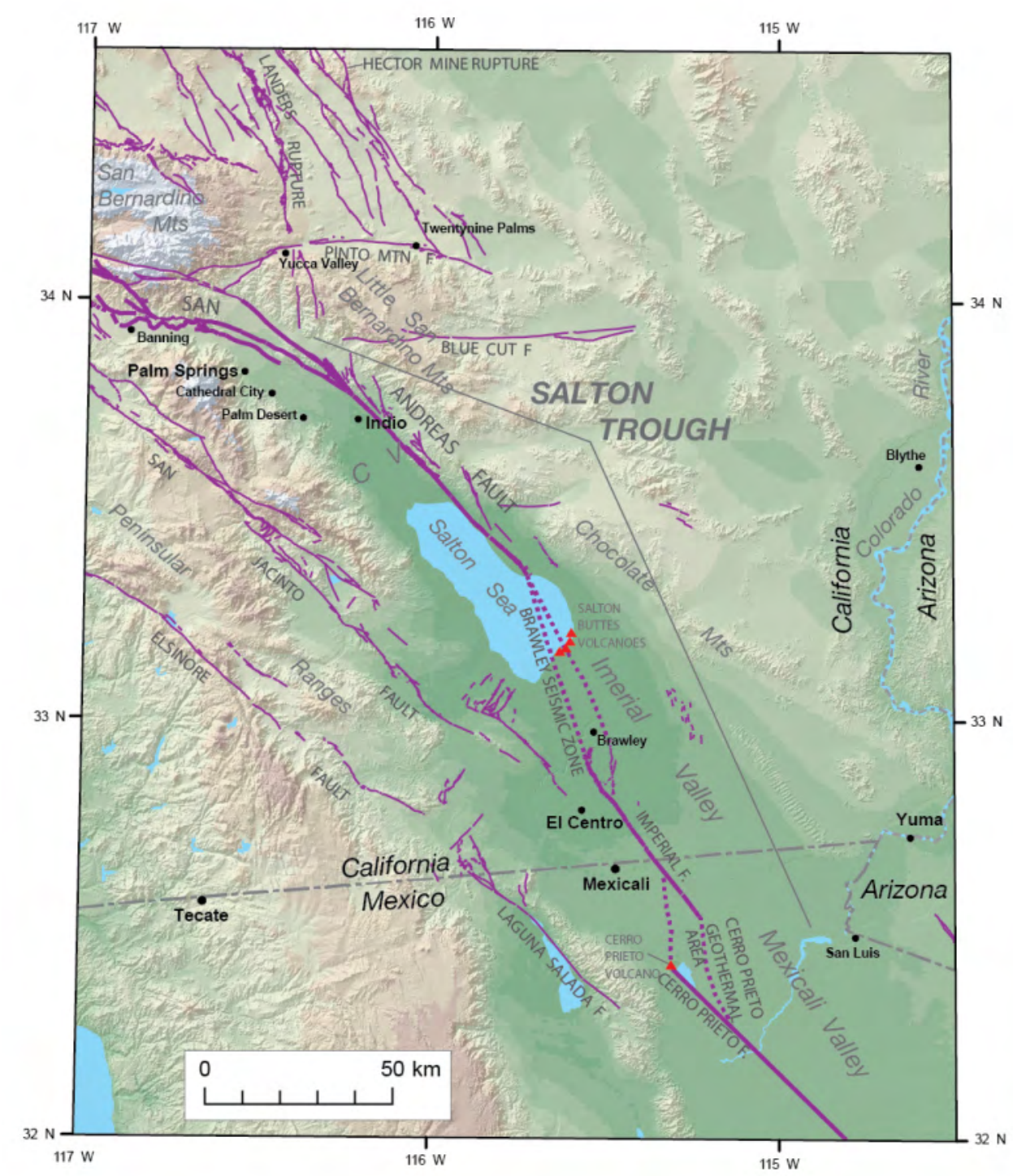

Figure 1a. Shaded relief map of southeastern California showing faults (thin magenta lines), including the boundary between the Pacific and North American Plates (heavy magenta lines) and the Salton Buttes volcanoes (red triangles). The Pacific Plate is to the southwest and North American Plate is to the northeast of the plate boundary.

\section{Geological and Geophysical Setting}

The Salton Trough is the northernmost extent of the Gulf of California rift system (for example, Elders and others, 1972; Lonsdale, 1989; Stock and Hodges, 1989). This rift system began forming after $12 \mathrm{Ma}$, when the Rivera triple junction jumped south many hundreds of km, placing the Pacific plate directly in contact with the western edge of North America along the entire length of the Baja California peninsula. Late Miocene plate-boundary deformation included extensional or transtensional faulting in the future region of the Gulf of California, and strike-slip faulting west of the Baja California 
peninsula. By about $6 \mathrm{Ma}$, nearly all of the plate- boundary slip became localized in the Gulf basins, effectively transferring Baja California and southwestern California to the Pacific Plate. This resulted in oblique northwest extension in a series of pull-apart basins in step-overs between long strike-slip faults, with the San Andreas Fault (SAF) being the northernmost of these strike-slip faults (fig. 2). Total opening is estimated to be about 300 $\mathrm{km}$ since 6.3 Ma along the entire length of the rift system (Oskin and others, 2001; Oskin and Stock, 2003; Dorsey and others, 2007). In the southern Gulf, the pull-apart rifts have extended to full seafloor spreading, while in the northern Gulf, despite the same total extension, they have not.

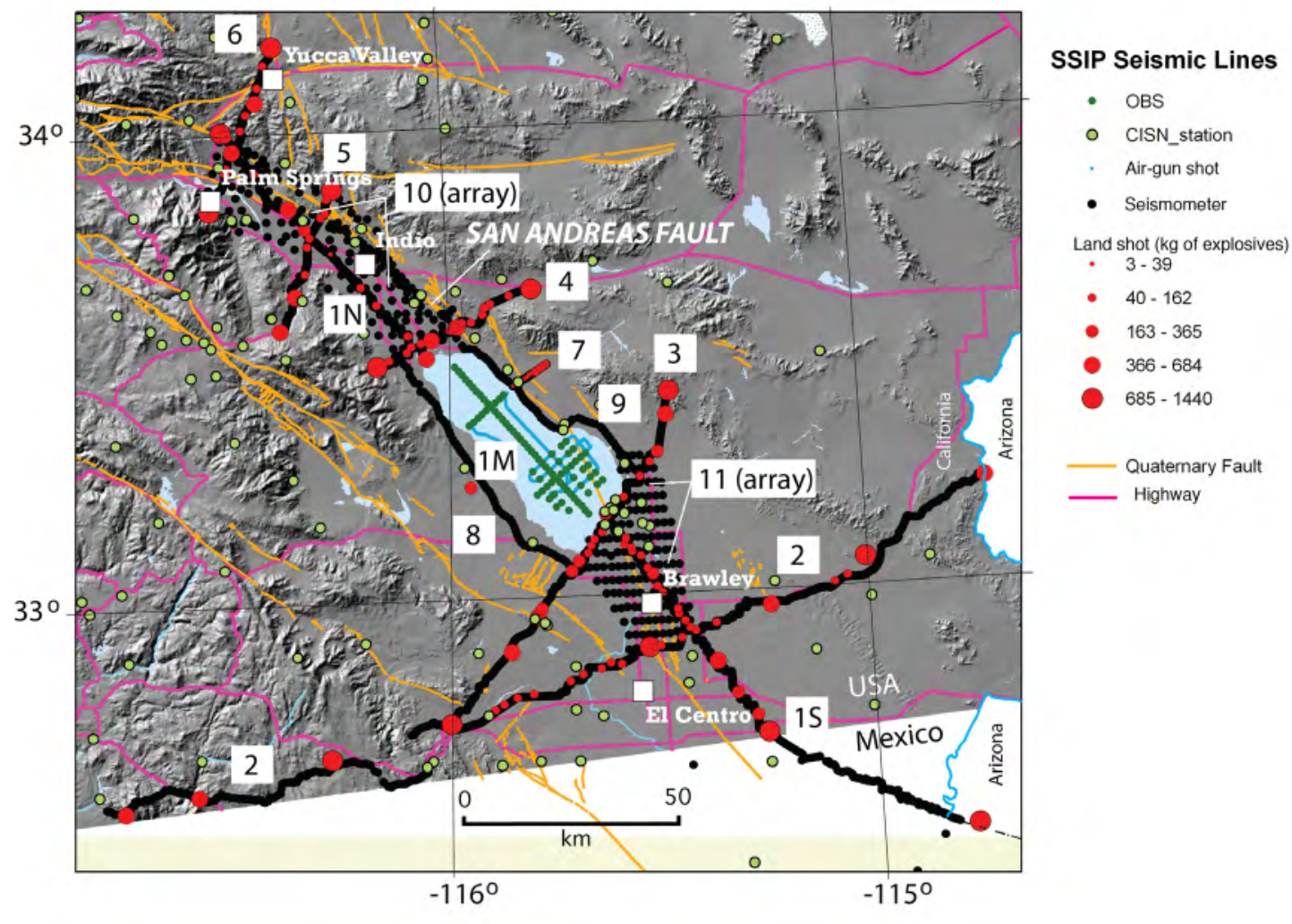

Figure $1 b$. Shaded relief map of southeastern California showing the Salton Seismic Imaging Project. Lines are numbered $1 \mathrm{~S} / 1 \mathrm{M} / 1 \mathrm{~N}$ through 11 (see text).

The Salton Trough was formed in part by oblique rifting between the strike-slip SAF and Imperial Fault near the Salton Sea, and between the Imperial and Cerro Prieto Faults in northern Mexico (fig. 1). The Superstition Hills-San Jacinto and Laguna SaladaElsinore Fault systems (fig. 1) are thought to be, in some sense, transform-fault extensions of the Imperial and Cerro Prieto Faults, which originate from a northward decrease in spreading rate from the Gulf of California to the Salton Sea (Lomnitz and others, 1970; Elders and others, 1972; see the northeast-striking, red, rectangular (schematic) spreading centers in fig. 2). All along the Gulf, the loci of extension have not been constant, but are marked by a series of abandoned inactive basins usually on the east side of the active rift basins (Stock, 2000; Aragon-Arreola and Martin-Barajas, 2007). 


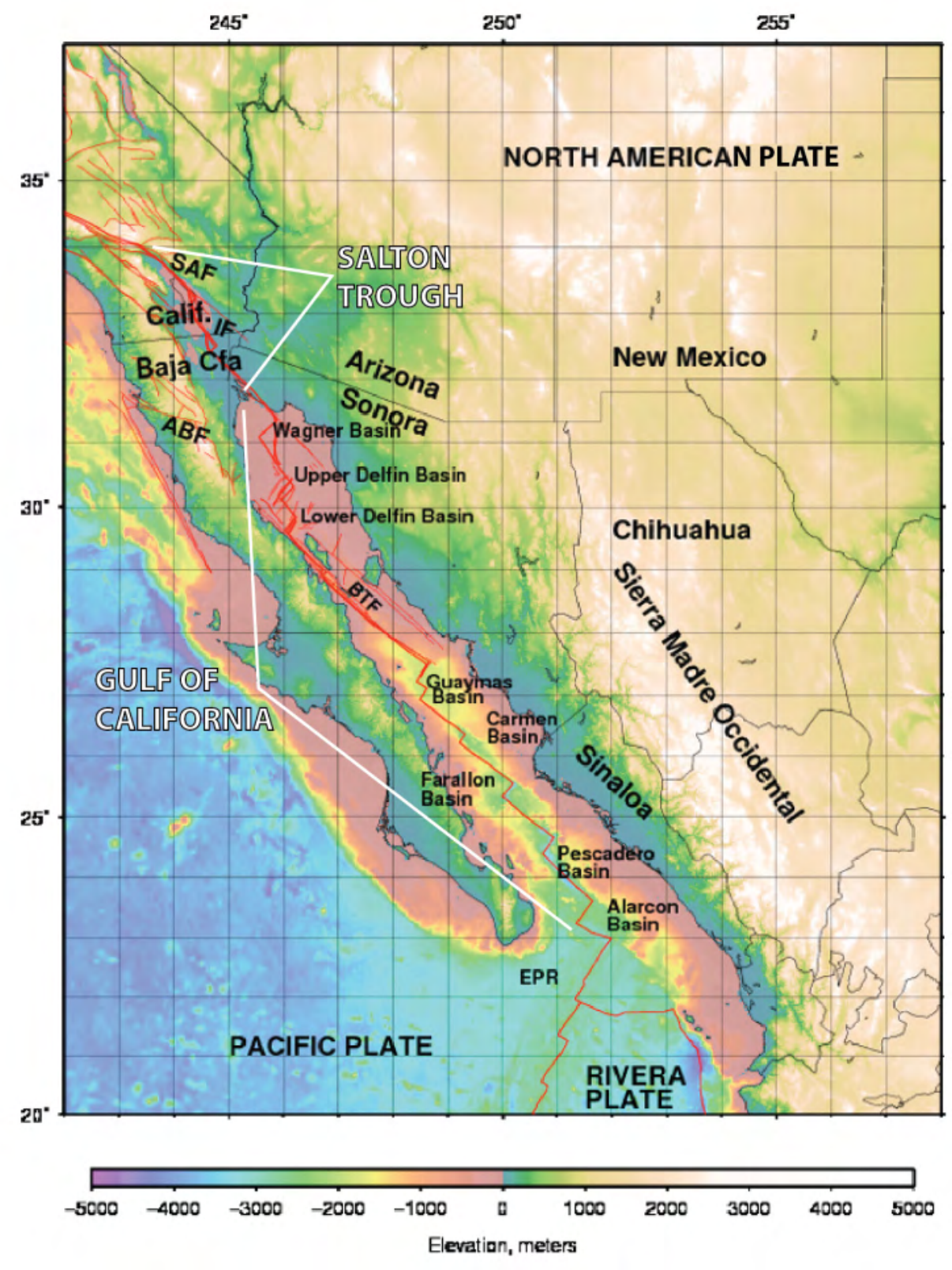

Figure 2. Tectonic map of the Gulf of California and Salton Trough, emphasizing oblique northwest extension accommodated by a series of pull-apart basins in step-overs between long strike-slip faults. ABF, Agua Blanca Fault; BTF, Ballenas Transform Fault; EPR, East Pacific Rise; IF, Imperial Fault; SAF, San Andreas Fault. The figure was made using Generic Mapping Tools software (Wessel and Smith, 1991) and the SRTM30plus world elevation database (Becker and others, 2009).

To the west of the Salton Trough, slip on low-angle faults of the West Salton and Laguna Salada detachment fault systems was contemporaneous with activity on the SAF system (Axen and Fletcher, 1998). The West Salton detachment fault dips east towards the Salton Sea, while the Laguna Salada system dips west. Motion along the West Salton detachment fault was deactivated in the Pleistocene (approximately 1.1 Ma) when it was 
crosscut by initiation of the San Jacinto Fault to the west (Kirby and others, 2007). The West Salton detachment fault has been uplifted and exposed along the western margin of the trough. The Superstition Hills-San Jacinto and Laguna Salada-Elsinore Faults now take up some of the plate motion rather than all of the motion stepping right to the Imperial Fault and SAF, as outlined above. The Laguna Salada detachment fault has late Quaternary displacement (Axen and Fletcher, 1998; Axen and others, 1999, Fletcher and Spelz, 2009) and faults in this region showed displacements during the April 4, $2010 \mathrm{El}$ Mayor-Cucapah earthquake sequence (Rymer and others, 2011; Hauksson and others, 2011; J.M. Fletcher and J.M. Stock, written commun., 2013).

The SAF terminates southward near the southeastern end of the Salton Sea. Motion is transferred to the Imperial Fault via the oblique Brawley seismic zone (fig. 1). A similar offset occurs between the Imperial and Cerro Prieto Faults at Cerro Prieto. Step-overs that are more rectangular in geometry than the Brawley seismic zone (BSZ) occur farther south, throughout the Gulf of California plate boundary zone (fig. 2). The step-overs are spreading centers connecting strike-slip (transform) faults (Lomnitz and others, 1970; Elders and others, 1972). In the Salton Trough, the oblique nature of the step-overs, or spreading centers, appears related to rapid burial by sediment of the Colorado River.

Two different domains of new crustal formation, one in the BSZ and the one near the Cerro Prieto geothermal area, are kinematically linked by the Imperial Fault —an onland analogy to the oceanic setting in which spreading centers are linked by a transform fault. There is volumetrically minor young volcanism and associated hydrothermal activity at the Salton Buttes along the southeastern shore of the Salton Sea (within the BSZ) and at Cerro Prieto (Robinson and others, 1976). Volumetrically minor volcanic rocks also are encountered in boreholes in the basins. Heat flow in the Salton Trough is much higher than in the areas surrounding it, averaging $140 \mathrm{~mW} / \mathrm{m}^{2}$ and exceeding 200 $\mathrm{mW} / \mathrm{m}^{2}$ in several active hydrothermal fields (Lachenbruch and others, 1985). Most earthquakes within the Salton Trough (fig. 3) lie between 6 and $10 \mathrm{~km}$ depth (Shearer, 2002; Hauksson and Shearer, 2005; Shearer and others, 2005; Lin and others, 2007), within the interpreted metasedimentary basement beneath the central part of the Salton Trough or within crystalline basement on the flanks of the trough (see below).

Sedimentation rate in the area of the Salton Buttes over approximately the last 0.5 Ma is estimated to be in the range of 2.2-3.8 mm/yr (Schmitt and Hulen, 2008).

Structure beneath the Salton Trough was imaged by a network of upper-crustal seismic refraction lines (Biehler and others, 1964; Fuis and Kohler, 1984; Fuis and others, 1984; Kohler and Fuis, 1986) and by a pair of whole-crustal refraction lines from the Imperial Valley to Arizona and from the Imperial Valley to the Coachella Valley (fig. 4; Parsons and McCarthy, 1996). The sedimentary basin within the Imperial Valley is 2-6 km deep (fig. 5; Kohler and Fuis, 1986), while the Coachella Valley basin is believed to be a few kilometers deep (Biehler and others, 1964). The western margin of the deep part of the basin in the Imperial Valley is steep and irregular, bounded by strands of the Superstition Hills-San Jacinto Fault system and by other buried faults (Fuis and others, 1984; Kohler and Fuis, 1986). The eastern margin is steep and linear, following an echelon southeastward extension of the SAF. A 0.5-1 km basement scarp underlies the Imperial Fault, dividing subbasins within the Imperial Valley (Fuis and others, 1984). 


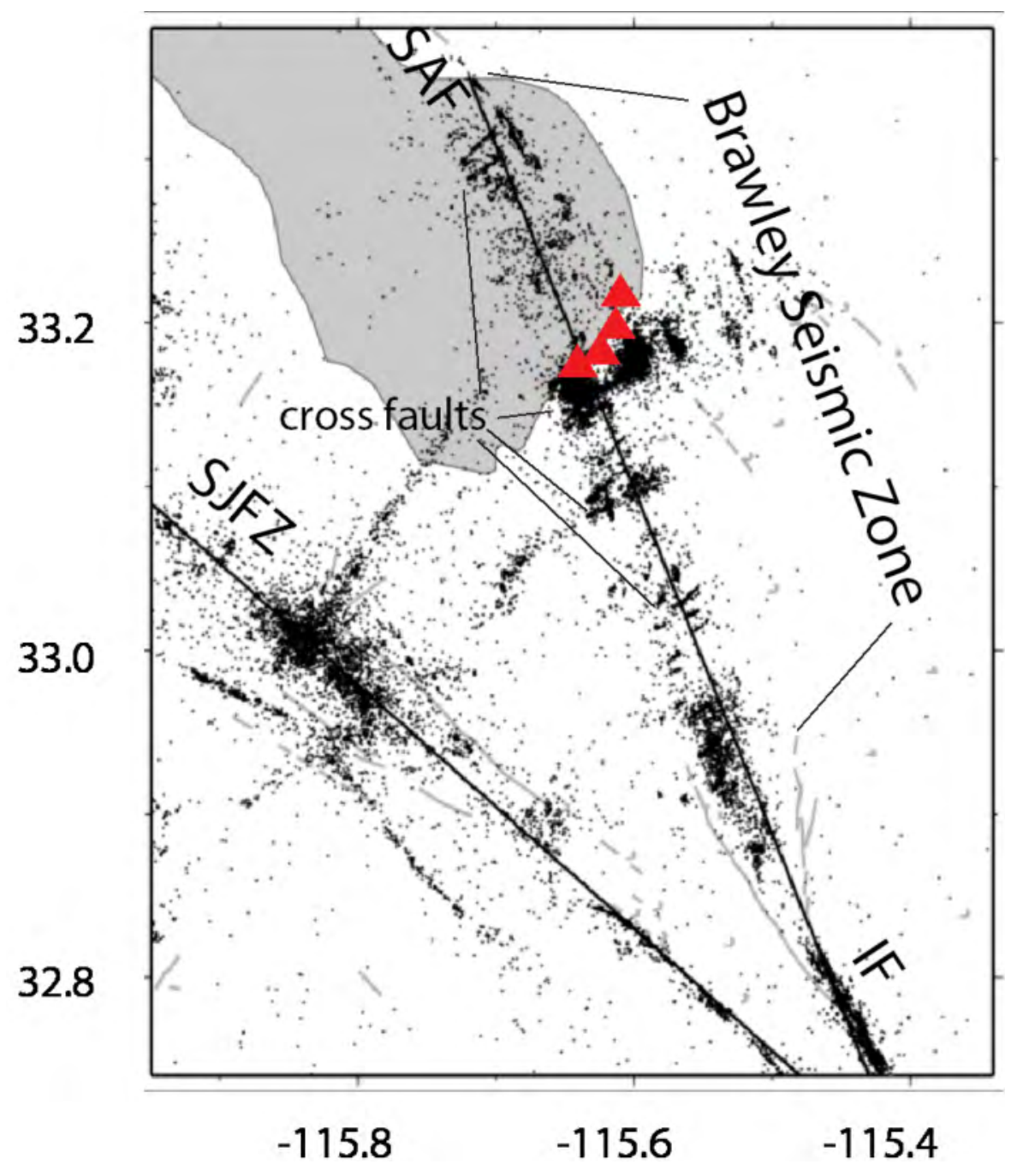

Figure 3. Map of seismicity and volcanoes in the southern part of the Salton Sea and northern part of the Imperial Valley. Red triangles are the Salton Buttes volcanoes. IF, Imperial Fault; SAF, San Andreas Fault; SJFZ, San Jacinto Fault zone. Adapted from Lin and others (2007, fig. 8).

Wells up to $4 \mathrm{~km}$ deep in the Imperial Valley have penetrated only Pleistocene sedimentary and volcanic rocks. Pleistocene uplift of the ranges on either side of the Trough exposes kilometers of late Miocene through Pleistocene sediments of the Colorado River (for example, Winker and Kidwell, 1986; Dorsey and others, 2007; Kirby and others, 2007), and these are presumed to underlie the deepest wells in the basin.

Basement beneath the Imperial Valley has a low seismic velocity of $5.6-5.7 \mathrm{~km} / \mathrm{s}$ and an apparently gradational upper surface (Fuis and others, 1984). Fuis and others (1984) interpreted, based on projected temperature profiles in wells and petrologic data, that basement is a metamorphosed facies of the sedimentary rocks above it. Additionally, the fact that basement depth decreases within geothermal areas (which have steep temperature gradients) may be further evidence that basement is metasediment. The provenance of the sedimentary and metasedimentary rocks in the Imperial Valley is observed to be chiefly the Colorado Plateau (Muffler and Doe, 1968; Dorsey and Lazear, 2011). 


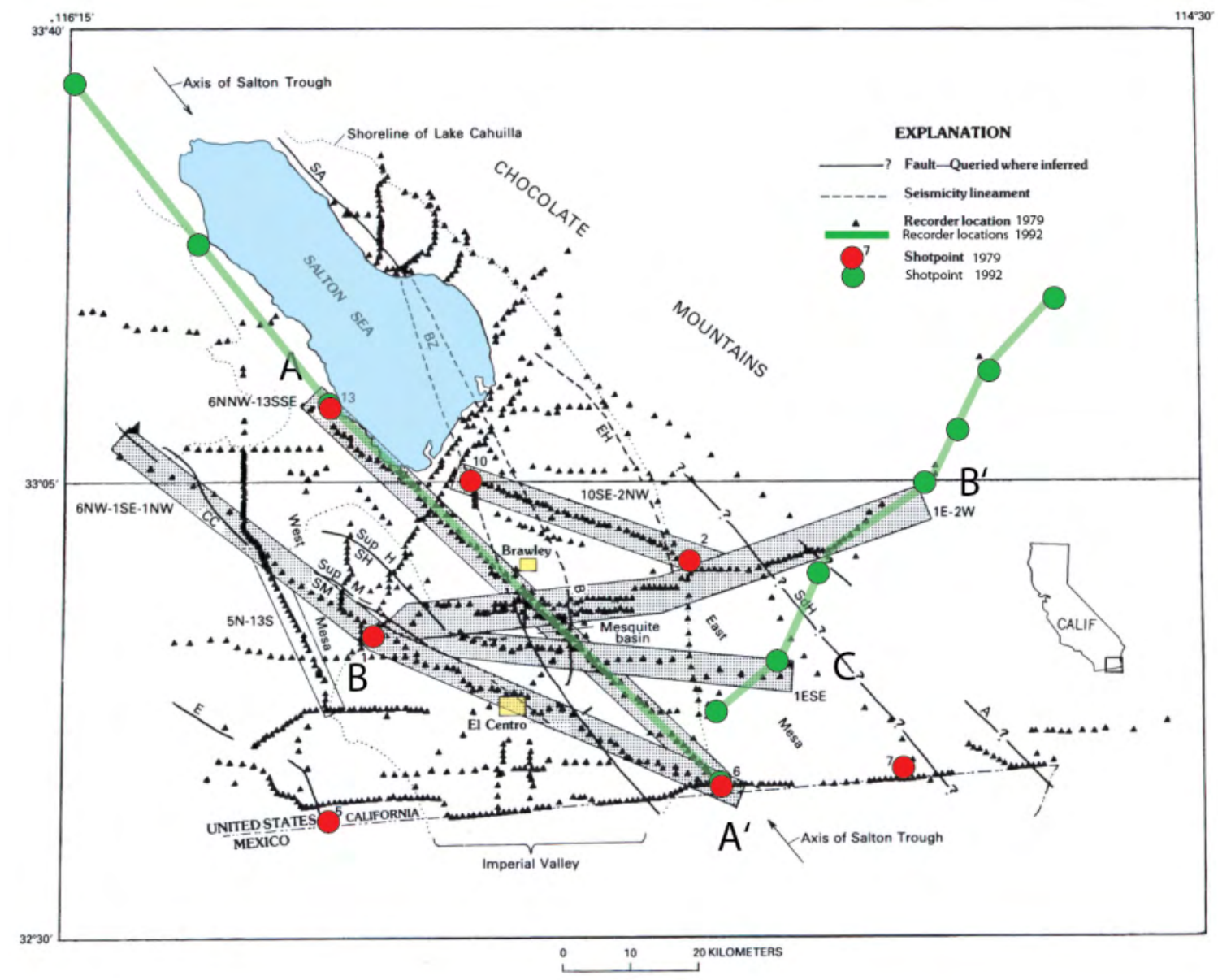

Figure 4. Map of southeastern California showing the 1979 (Fuis and others, 1984) and 1992 (Parsons and McCarthy, 1996) seismic-imaging projects in the Imperial Valley region. A, Algodones Fault; B, Brawley Fault zone; BZ, Brawley seismic zone; CC, Coyote Creek Fault; E, Elsinore Fault; EH, East Highline Canal seismicity lineament; I, Imperial Fault; SA, San Andreas Fault; SdH, Sand Hills Fault; SH, Superstition Hills Fault; SM, Superstition Mountain Fault. Sup H, Superstition Hills; Sup M, Superstition Mountain. Adapted from Fuis and others (1984); lines A-A', $B-B^{\prime}$, and $C-C^{\prime}$ refer to cross sections shown with original figure.

Older crystalline basement on the surrounding mesas and mountains has a higher velocity of 5.9-6.0 km/s and a sharp, seismic contact with overlying sediment. A much faster $6.9-7.5 \mathrm{~km} / \mathrm{s}$ layer is encountered at 10-16 km depth beneath the Imperial Valley (Fuis and others, 1984; Parsons and McCarthy, 1996). This faster, mafic layer extends 30-40 km east of the Imperial Valley, pinching out under the Chocolate Mountains (Larkin and others, 1996; Parsons and McCarthy, 1996). Its western, northern, and southern extents have not been mapped, but gravity suggests it does not extend beneath the Peninsular Ranges or the Coachella Valley (fig. 6, 3.1 g/cc layer; Fuis and others, 1984). Such high midcrustal velocities have not been observed under the surrounding regions. 
The Moho is 21-22 km under the Imperial Valley and deepens to $27 \mathrm{~km}$ under the Chocolate Mountains to the east (Parsons and McCarthy, 1996). The Moho deepens to

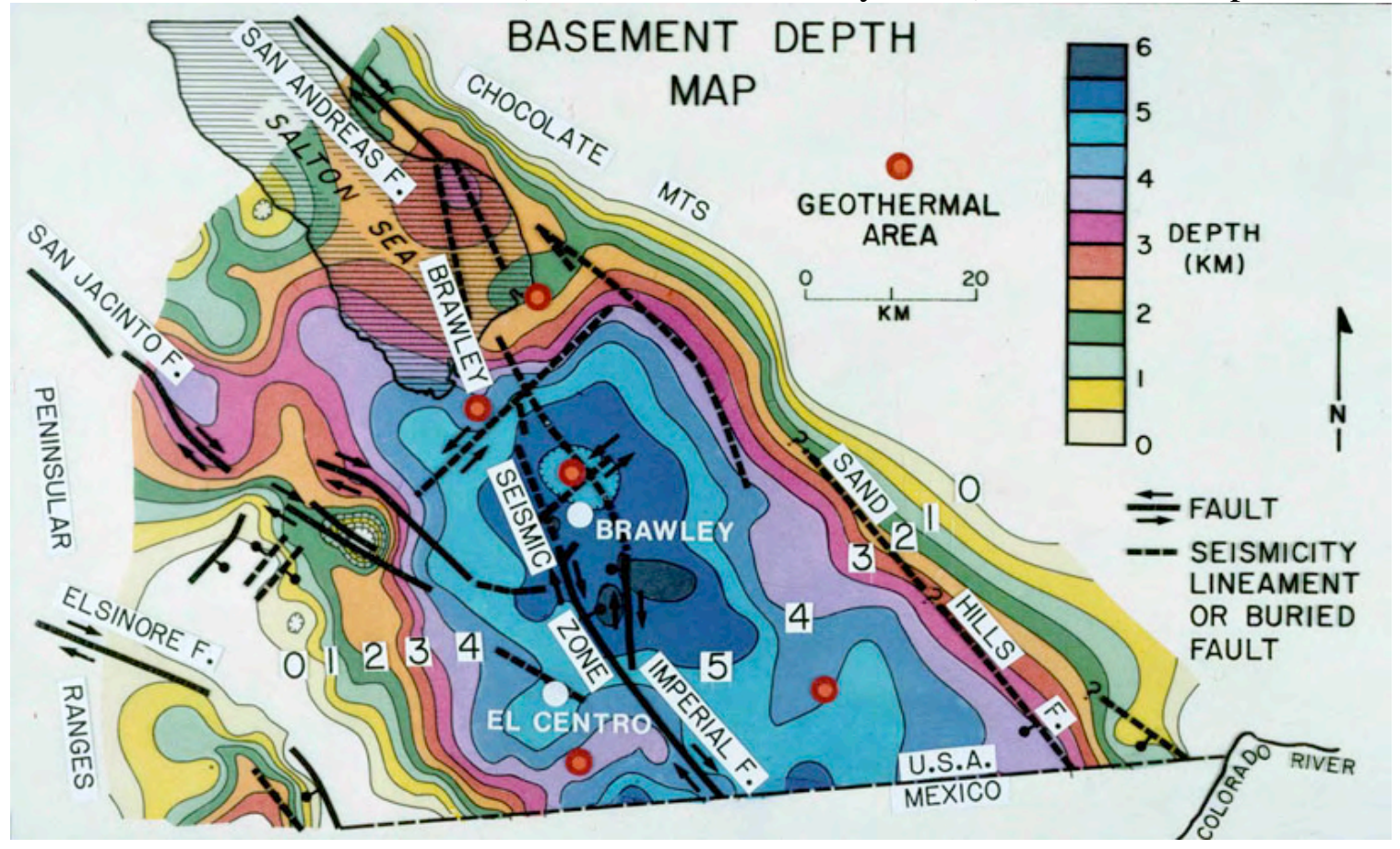

Figure 5. Map of southeastern California showing basement depth calculated from time-term analysis. Adapted from Kohler and Fuis (1986, fig. 11).

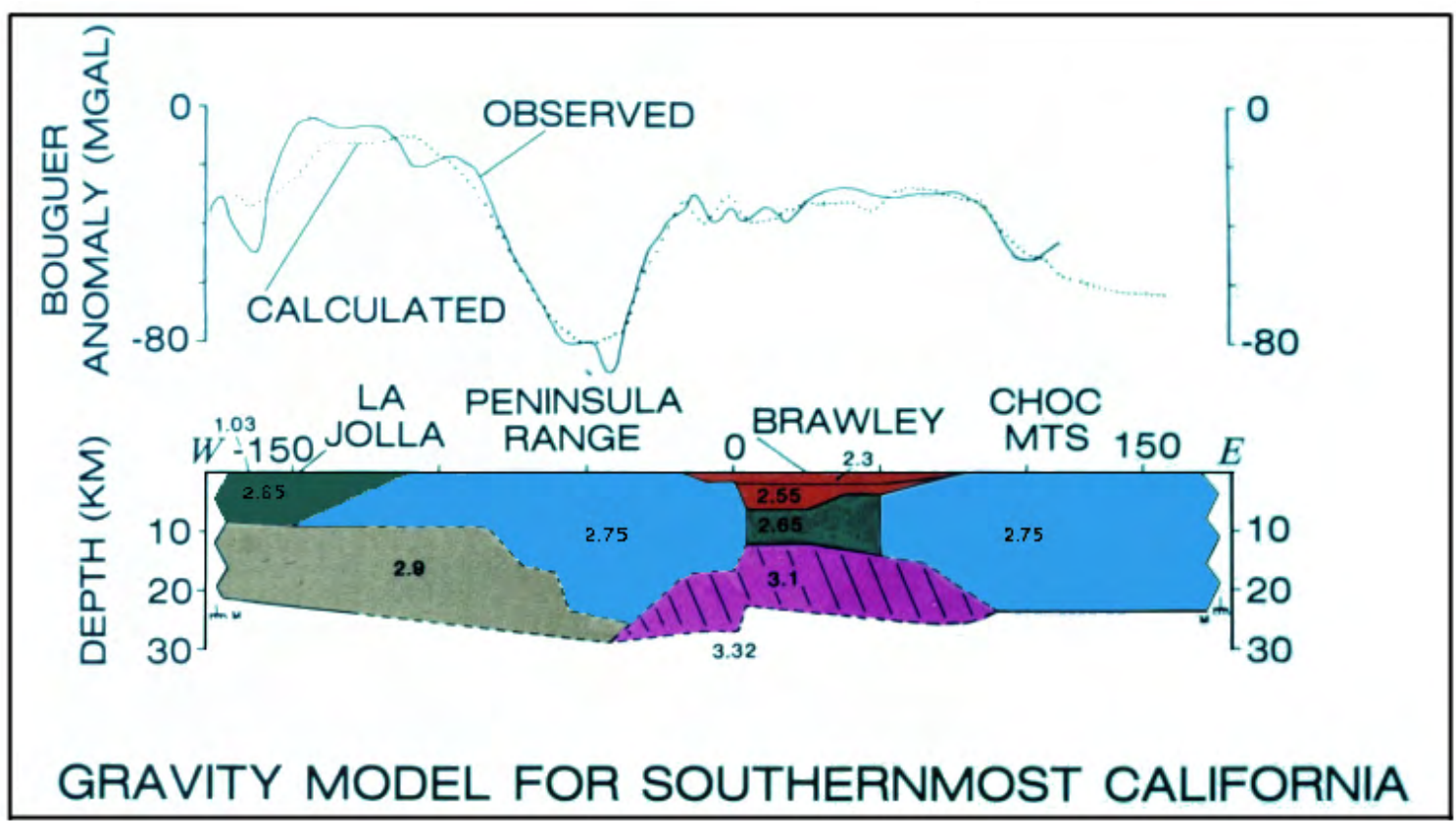

Figure 6. Cross-section of southernmost California based on gravity data between San Diego (W) and the California-Arizona border (E). Densities are in grams per cubic centimeter ( $\mathrm{g} / \mathrm{cc}$ ). Adapted from Fuis and others (1984). 
more than 26 km under the eastern-most Peninsular Ranges (Ichinose and others, 1996; compare with gravity model of fig. 6). Upper mantle seismic velocity is $7.6-7.7 \mathrm{~km} / \mathrm{s}$ under the Imperial Valley, typical of hot continental rift environments, and 8.0-8.1 km/s under the Chocolate Mountains (Parsons and McCarthy, 1996). Low mantle seismic velocity under the Salton Trough extends to 200-km depth (for example Zhao and others, 1996; Tanimoto and Sheldrake, 2002; Kohler and others, 2003; Yang and Forsyth, 2006).

\section{Questions to be Addressed by the Salton Seismic Imaging Project}

The Salton Seismic Imaging Project was designed to address several main questions, including:

1. How does the crustal structure of the Coachella Valley differ from that of the Imperial Valley? In particular, are there deep sedimentary basins? Does the basement consist of older crystalline rocks or younger metasedimentary rocks?

2. What is the dip of the San Andreas and Imperial Faults, which constitute the major parts of the plate boundary in the Salton Trough? In particular, does the SAF dip moderately to the northeast, as postulated by Fuis and others (2012)? Does the Imperial Fault also dip moderately to the northeast, as found by Fuis and others (1984)?

3. What is the shape of, and the velocity distribution, within the sedimentary basins of the Salton Trough?

4. Is the basement of the Imperial Valley composed of young metasedimentary rocks, as postulated by Fuis and others (1984)? In particular, are there any blocks of older crystalline rocks left behind from the rifting process in this region?

5. If basement rocks differ between the Coachella and Imperial Valleys, where is the suture? Is it under the Salton Sea?

6. How is the Salton Trough subsiding? Most of the earthquakes were determined to be strike-slip and aligned along steeply dipping faults (fig. 3; Hardebeck and Hauksson, 2001). Subsidence cannot be accommodated on these seismically illuminated faults, so how does it happen?

7. What is the nature of magmatism? In particular, is it localized and minor, as seen today in the Salton Buttes and Cerro Prieto, or is it diffuse or nonstationary as postulated by Lachenbruch and others (1985)?

8. What is the geometry of the mafic midcrustal layer as it extends northward toward the Coachella Valley? In particular, does it deepen and pinch out, as it does under the Chocolate Mountains and Peninsular Ranges (fig. 6)?

9. How do Moho depth and mantle seismic velocity vary in the Salton Trough region? Can prior results be substantiated and improved upon?

The first three questions are important to the assessment of earthquake hazards in the Salton Trough. Predictions for ground shaking following major earthquake rupture(s) depend strongly on fault dip and on the local seismic-velocity distribution, depth, and shape of sedimentary basins. The USGS is focused on answers to these questions in order to improve the ground-motion predictions of, for example, the ShakeOut exercise (Jones and others, 2008; Perry and others, 2008), an earthquake preparedness exercise for the 
public and emergency managers. In addition, the crustal velocity structure of the entire region must be well known in order to accurately locate earthquakes. The last six questions are important to understanding the nature of rifting and magmatism in the Salton Trough. University collaborators (Virginia Tech, Caltech, Scripps, and UNR), funded by NSF, are focused on answers to these questions. In addition to U.S. universities, Mexican institutions, including Centro de Investigacion Cientifica y de Educacion Superior de Ensenada (CICESE) in Ensenada, Mexico, and Universidad Autonoma de Baja California in Mexicali, Mexico, participated in the project to obtain answers to some of these questions for the northern part of Baja California.

\section{Prior Crustal-Structure Work}

Crustal-structure investigations of the Salton Trough began with the early seismic refraction profiles of Kovach and others (1962) and Biehler and others (1964). These profiles were relatively short (less than $12 \mathrm{~km}$ ) and located in geographically separate areas of the Salton Trough. With the help of well data, these authors documented basement depth ranging from approximately 1.5 to $2.5 \mathrm{~km}$ in the Coachella Valley, and from 1 to $6 \mathrm{~km}$ in the Imperial Valley. In 1979, the USGS conducted a geographically extensive seismic refraction survey of the Imperial Valley (Fuis and others, 1984), followed in 1992 by two additional regional profiles (Parsons and McCarthy, 1996) (fig. 4). In the 1979 survey, 100 seismometers were deployed in nearly 1,200 locations, and 42 shots were detonated at 7 shot points. Seismometer spacing was generally on the order of 1-km intervals. The 1979 survey was quite modest in comparison with the SSIP, where 2,709 seismometers were deployed at 4,341 locations, generally spaced 100-200 m apart (except in the mountains), and 126 shots were detonated at 123 on-land shot points. Additionally, in SSIP, 48 OBSs were deployed at 78 underwater locations, and 2,381 airgun shots were fired in the Salton Sea.

From the large areal coverage in the 1979 survey (fig. 4), basement depth was mapped over much of the Imperial Valley and surrounding region (fig. 5; Kohler and Fuis, 1986). As discussed above, basement beneath the central part of the Imperial Valley was discovered to have relatively low velocities $(5.6-5.7 \mathrm{~km} / \mathrm{s})$ and was interpreted to consist of a metamorphic facies (greenschist facies) of the young sediments above it. In addition, the crustal cross section (fig. 6), documented in the central part of the Imperial Valley from the 1979 seismic survey, was extended east and west using gravity modeling to interpret the pinch-out of the mafic midcrustal layer beneath the Peninsular Ranges and Chocolate Mountains (Fuis and others, 1984; Lachenbruch and others, 1985). From the regional profiles of 1992, the pinch-out of the mafic midcrustal layer was confirmed beneath the Chocolate Mountains (Parsons and McCarthy, 1996).

\section{Experiment Design}

Generally, the SSIP was laid out as a series of intersecting lines that produce an approximate 3-D image of the subsurface, mainly in the Coachella and Imperial Valleys (fig. 1b). The survey included an axial line beginning at the southwest tip of Arizona and extending northwestward through the Mexicali, Imperial, and Coachella Valleys to a point north of Palm Springs, California. Cross lines were laid out in northeasterly directions straddling the SAF and Imperial Fault, which are both located within the 
valleys. These lines extended beyond the edges of the valleys so that we could image the full shapes of the sedimentary basins beneath the valleys. The following paragraphs describe each line, and the PIs' objectives in designing them.

Line 1 was composed of segments $1 \mathrm{~S}$ (south), $1 \mathrm{M}$ (marine), and $1 \mathrm{~N}$ (north) (fig. $1 b$ ). $1 \mathrm{~S}$ is the part of the line from the southwest tip of Arizona that extended northwestward across a corner of Mexico, back into the U.S. east of El Centro, Calif., and northwestward to the Salton Sea. Segment $1 \mathrm{~N}$ began on the north shore of the Salton Sea and extended to the northwest end of the Coachella Valley. Segment 1M was the marine component (in the Salton Sea) connecting $1 \mathrm{~S}$ and $1 \mathrm{~N}$. This axial line was intended to image the deepest parts of the sedimentary basins in the Salton Trough (estimated to reach depths as great as $6 \mathrm{~km}$ ). Shaking severity from earthquakes increases with basin depth; therefore, knowing the basin depth and its variations is important for evaluating the earthquake hazard. This long line also would allow us to investigate the composition of the crust and the underlying mantle, and would provide an answer to the question: at what point northwestward in the Salton Trough do magmatic contributions to the crust cease? Currently, the northernmost surface manifestations of magmatic intrusions are the (active) Salton Butte volcanoes at the southeast end of the Salton Sea. There is, however, an intrusive basaltic middle to lower crust that deepens northward beneath the Salton Sea (Fuis and others, 1984). Line 1 should resolve where this basaltic intrusion pinches out.

Line 2 extended from a point on the international border east of San Diego, Calif. northeastward to the Colorado River south of Blythe, Calif. (fig. 1b). This line crossed the Peninsular Ranges, Imperial Valley, and Chocolate Mountains. The line was intended to improve upon the image of the sedimentary basin shape obtained on line 1S, by extending it to the east and west. This would allow for a better evaluation of earthquake shaking hazard within the Imperial Valley. This line would also image the geometry (dip) of the Imperial fault, so that earthquake-energy radiation from this plate-boundary fault can be better estimated. This fault has generated two large earthquakes in the last 70 years, the 1940 M6.9 and 1979 M6.4 earthquakes. Other active faults in the Peninsular Ranges, such as the Elsinore and San Jacinto Faults, can also generate moderate earthquakes and thus should be imaged. In addition, this line was intended to image the older rocks on either side of the Imperial Valley and the boundaries between these rocks and the new crust. This new crust consists of sediment in the upper crust and intrusive basaltic rocks in the mid-to-lower-crust (Fuis and others, 1984). Where does this mafic layer pinch out westward?

Line 3 extended from Line 2 on the west side of the Imperial Valley, northeastward through the Salton Buttes volcanoes, along the south shore of the Salton Sea, and into the Chocolate Mountains (fig. 1b). This line crossed one of the rifts in the Salton Trough, the Brawley seismic zone (fig. 3), where magmatic intrusions into the crust are active. In addition to addressing sedimentary basin depth, this line was intended to investigate the quantity and shapes of magmatic materials that have been added to the upper part of the crust, and the sizes and locations of active magma chambers below the volcanoes. This line also was intended to distinguish between the steep, seismically active faults of the BSZ (fig. 3) and any (aseismic) normal faults, which are required for subsidence to occur. Our investigation also may be of general use to the geothermal industry in this area. Finally, this line was intended to investigate branches of the San 
Jacinto Fault known as the Superstition Hills and Superstition Mountain Faults. The Superstition Hills Fault ruptured in an M6.6 earthquake in 1987.

Lines 4, 5, and 6 were intended, like lines 2 and 3, to extend our knowledge of sedimentary basin thickness (and hence earthquake shaking severity) in as many locations as feasible in the Coachella Valley (fig. 1b). Rapid urban and suburban growth in the Coachella Valley requires expedited evaluation of earthquake shaking hazard. The location of line 4 was chosen so that we could straddle the SAF and obtain an image of not only the sedimentary basins on either side of the fault, but also of the fault itself (and its dip). Microseismicity suggests that the fault dips moderately northeastward here (Lin and others, 2007); hence, it is important to confirm or reject this possibility because of its implications for energy radiation during a major earthquake. Line 5 was chosen to address the sedimentary basin depth beneath Palm Desert, Calif., one of the large suburban cities of the Coachella Valley, and was designed to take advantage of access southwestward into the Peninsular Ranges along Highway 74. Line 6 was chosen to address the basin depth in the vicinity of Palm Springs, the largest urban area in the Coachella Valley, while also taking advantage of access through the Little San Bernardino Mountains along the "Kickapoo Trail" (a dirt road from Desert Hot Springs to Yucca Valley). Line 6 was intended to image the SAF where it has split into three branches, the Garnet Hill, Banning, and Mission Creek faults. The M 6+ earthquakes of 1948 (Desert Hot Springs) and 1986 (North Palm Springs) appear to have occurred on either the Banning or Garnet Hill branches, which dip moderately northward, and it is important to investigate the structure of the fault zone here (northward dips) for earthquake hazard evaluation. Lines 5 and 6 terminated near the ruptures of the 1991 M6.1 Joshua Tree and 1992 M7.3 Landers earthquakes, respectively.

Line 7 was a 9-km-long profile that crossed the SAF at Salt Creek, on the northeast shore of the Salton Sea. There, microseismic evidence suggests that the SAF dips $57-59^{\circ} \mathrm{NE}$ (Lin and others, 2007). Therefore, line 7 was the best location to obtain a crisp image of the fault, in order to confirm or reject the northeastward dip hypothesis. We deemed it important to obtain independent seismic imaging data for this stretch of the SAF for earthquake hazard evaluation. Line 7 was extended offshore with air guns and OBSs.

Lines 8 and 9 were deployments of seismometers along the southwestern and northeastern shores of the Salton Sea, respectively, to supplement data from Line 1M in the sea itself (fig. $1 b$ ).

Lines 10 and 11 were actually arrays of seismometers in the Coachella and Imperial Valleys, respectively (fig. 1b), deployed in order to make maps of basement topography, as was done in the 1979 Imperial Valley seismic survey of Kohler and Fuis (1986).

Mexican PIs deployed additional Texan seismometers on line 1S in Mexico in 106 locations.

\section{Division of Labor}

The SSIP tasks were divided according to each organization's capabilities and resources. The USGS took charge of the acquisition of permits, borehole drilling (128 drilled holes and 61 hand-augered holes), loading and detonating the explosive charges, and remediation of blast sites. With funding from NSF, Virginia Tech and Caltech PIs 
took responsibility for the deployment of seismometers (at 4,235 locations) and assisted the USGS with some of the permitting, supervision of borehole drilling, and cleanup. Scripps and UNR PIs used NSF funds to coordinate and execute the deployment of OBSs at 78 locations in the Salton Sea and the firing of 2,381 air gun shots from a specially constructed barge assembled on the Salton Sea. Table 1 illustrates the timing of these tasks.

Table 1. Experiment schedule.

\begin{tabular}{lrrl}
\hline \multicolumn{1}{c}{ Tasks } & Start date & $\begin{array}{c}\text { Duration } \\
\text { (days) }\end{array}$ & End date \\
\hline Permitting & $4 / 1 / 08$ & 1078 & $3 / 15 / 11$ \\
Drilling & $10 / 6 / 10$ & 160 & $3 / 15 / 11$ \\
Loading & $1 / 12 / 11$ & 62 & $3 / 15 / 11$ \\
Deployment & $2 / 28 / 11$ & 17 & $3 / 17 / 11$ \\
Shooting & $3 / 2 / 11$ & 14 & $3 / 16 / 11$ \\
Cleanup & $4 / 15 / 11$ & 122 & $8 / 15 / 11$
\end{tabular}

\section{Experiment Schedule}

The SSIP proposal was submitted to the NSF in 2007 by John Hole of Virginia Tech, Joann Stock of Caltech, and Gary Fuis of the USGS. The proposal was funded in early 2008. Permitting began shortly afterwards, in the spring of 2008, and continued until drilling was completed. Drilling began on October 6, 2010, and was nearly continuous until March 16, 2011. The USGS and Virginia Tech contracted one drilling company, which subcontracted to two other drilling companies at certain times during the project in order to ensure that all shot points would be drilled on schedule. The explosives-loading phase began on January 12, 2011, and continued until the last shot holes were drilled and loaded on March 15, 2011. While the USGS was busy coordinating drilling, and loading shot holes, Caltech and Virginia Tech led the seismometer deployment effort. Seismometer deployment began on February 28, 2011, and the first seismic shots were detonated on the night of March 2. During the period February 28 through March 16, instruments were deployed, picked up, and redeployed, for a total of 4,235 individual instrument deployments. All instruments were picked up on March 17, 2011, following the final night of shooting. The cleanup effort was substantial. The USGS coordinated and completed drill/blast site remediation between April and August 2011. Data processing and analysis began as soon as the Incorporated Research Institutions for Seismology Program for Array Seismic Studies of the Continental Lithosphere (IRIS PASSCAL) compiled and distributed all shot data (May 2011). The data were made available to all participating universities and organizations. All land data will be publicly available after March 2013 through the IRIS Data Management Center (www.iris.edu/dms/dmc).

\section{Permitting}

Permitting for the SSIP began in spring 2008 and continued through the weeks of shooting. Permitting was a very time-consuming and essential component of the project. It required hundreds of letters, emails, and telephone calls, and had to be done in a 
systematic way. The correspondence table (table 2) indicates the magnitude of the permitting effort. We attempted to permit about 331 different sites for shot points. In addition to shot point permits, many permits also were sought out to facilitate the installation of seismometers on private land. Most instruments, however, were installed along easements and roadways, and therefore did not require permits.

Table 2. Permitting: entities involved.

\begin{tabular}{lrr}
\hline Type of entity & $\begin{array}{c}\text { Number of } \\
\text { entities } \\
\text { consulted }\end{array}$ & $\begin{array}{c}\text { Number of } \\
\text { permitted } \\
\text { sites with } \\
\text { shot points } \\
\text { completed }\end{array}$ \\
\hline Federal Government agencies & 9 & 53 \\
Native American tribes & 37 & 6 \\
State Government agencies & 9 & 5 \\
County agencies & 3 & 0 \\
City or regional organizations & 6 & 10 \\
Private landowners & 179 & 49 \\
Totals & 243 & 123 \\
\hline
\end{tabular}

The permitting process began with scouting. Shot points were scouted (according to the PIs' plans for each seismic line) using Google Earth ${ }^{\mathrm{TM}}$ and/or by visiting potential sites. Next, land ownership was determined by searching databases and parcel owner information online and/or by consulting with county and city assessors' offices. Once ownership was determined, a letter asking permission and a map showing the location of the proposed shot point location(s) were sent to the landowner(s).

It was necessary to visit each shot point site in order to verify that our buried explosions would not damage nearby structures, utilities, or roads, and to ensure compliance with the National Environmental Policy Act (NEPA). We had to ensure that drilling and shooting would pose no threats to cultural resources, including archaeological features, as well as threatened or endangered species of wildlife and plants. To protect cultural resources on government (State and Federal) lands, we contracted a commercial archaeological firm to visit and document each shot point site. We then contacted the 37 Native American Tribes who had formerly occupied parts of the region within the footprint of the SSIP, and provided our archaeological report. To protect cultural resources on county, city, or private lands, we performed a literature search (by contract) and photographed each site and its surroundings. Results from all sites were reviewed for NEPA compliance by the California State Historic Preservation Office (SHPO). Seismometer installations, involving generally a shovel-deep hole, were exempt from NEPA documentation except for those along the southwestern half of Line 7. On this part of Line 7, a Native American monitor accompanied our deployment crews. To protect threatened and endangered species on government (State and Federal) lands, we took actions described below. Finally, before the start of drilling, we marked the exact location of each proposed shot hole so that utility companies could confirm that we would not be drilling into underground pipelines or cables.

Permitting for shot points on land owned by the Torres Martinez Desert Cahuilla Indian Tribe, on lines 1 and 4, required some additional steps. An excavation permit was 
first obtained from the tribe, under the supervision of the Bureau of Indian Affairs. During drilling on tribal land, a Native American monitor was present to inspect drill cuttings for potential artifacts. In total, we drilled seven shot holes on Torres Martinez lands in the Coachella Valley.

In areas recognized as habitat for threatened and endangered species, certified biologists had to be present during all activities, including drilling, loading, shooting, and cleanup. Shot sites proposed on Bureau of Land Management (BLM) land, under the jurisdiction of the Palm Springs Field Office (Riverside and San Diego Counties), were inspected by a staff biologist months before drilling and shooting began. The biologist then trained PIs, USGS personnel, and the contracted drillers on the endangered desert tortoise's behavior and habitat, and on avoiding other sensitive species. The USGS "drill watcher" was designated the official on-site desert tortoise monitor for the Coachella Valley BLM sites. For seismometer sites in the fringe-toed lizard preserve near the center of line 5, a certified biologist accompanied the deployment crew. Shot sites in the BLM El Centro Field Office's jurisdiction (Imperial County), which included military bases and bombing ranges, required a certified biologist to be on site during all activities. We used both USGS and private biologists to monitor our activities. In Imperial County, the BLM was concerned about multiple species of endangered lizards, as well as the endangered desert tortoise. None of the listed species were detected at any shot-hole sites, nor determined to be impacted by drilling, shooting, or cleanup.

\section{Land Shot Size Determination}

Shot size was determined in much the same way as it was during LARSE II (Fuis and others, 2001b). In this procedure, amplitude data from prior experiments (peak ground velocity, in $\mathrm{cm} / \mathrm{s}$ ) were plotted againt distance and fit with two curves: one with no distance weighting, and one where individual data points were weighted by distance. The latter curve systematically predicted higher amplitudes than the former curve at distances less than $10 \mathrm{~km}$; hence shot size was determined by averaging the predictions from the two curves.

The calibration shots that were detonated in the Imperial Valley in 2009 (Murphy and others, 2010) demonstrated that shots in soft lake sediments followed the nodistance-weighting curve quite closely. Therefore, for such sites, we used that curve alone. For all other sites in SSIP, we used the averaged predictions of both curves.

"Distances of concern" were the distances to the nearest man-made structures. Several peak ground velocity thresholds were tested to determine the maximum sizes allowable for each shot. For example, for occupied modern structures, peak ground velocities were kept below $2.5 \mathrm{~cm} / \mathrm{s}$ (1 in/s) at a 95-percent confidence level to avoid human complaints. For unoccupied modern structures, peak ground velocities were kept below $5 \mathrm{~cm} / \mathrm{s}$ (2 in/s) at a 95-percent confidence level to avoid cosmetic damage. Lastly, for engineered structures (canals, bridges, dams, and so on), peak ground velocities were kept below $12.5 \mathrm{~cm} / \mathrm{s}$ (5 in/s) at a 90-percent confidence level to avoid damage.

Shot sizes ranged from 3-1,367 kg (6-3,000 lbs; table 3). The smaller shots were simply boosters loaded into 3-5 m deep (10-15 ft) hand-augered holes. The largest shots

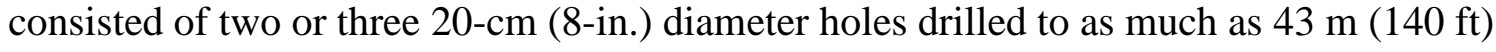
depth, loaded with blasting agent (totaling as much as $1,367 \mathrm{~kg}$, or 3,000 lbs), and detonated simultaneously. 
Table 3. Land shot-hole loading details for 23 shot points. Full details for all shot points from the Salton Seismic Imaging Project are given in appendix VIII.

\begin{tabular}{|c|c|c|c|c|c|c|c|c|c|c|c|c|c|c|c|c|c|c|c|c|}
\hline $\begin{array}{l}\text { Shot } \\
\text { point \# } \\
\text { (final) }\end{array}$ & $\begin{array}{c}\text { Shot } \\
\text { point \# } \\
\text { (original) }\end{array}$ & $\begin{array}{c}\text { Hole } \\
\text { depth } \\
\text { (ft) }\end{array}$ & $\begin{array}{c}\text { Depth } \\
\text { of steel } \\
\text { casing } \\
\text { (ft) }\end{array}$ & $\begin{array}{c}\text { Casing } \\
\text { diameter } \\
\text { (in) }\end{array}$ & \begin{tabular}{|c|} 
Depth to \\
water \\
before \\
loading \\
(ft)
\end{tabular} & $\begin{array}{c}\text { Detonating } \\
\text { cord length } \\
\text { (ft) }\end{array}$ & $\begin{array}{l}\text { Det. cord } \\
\text { weighted }\end{array}$ & $\begin{array}{c}\text { Booster } \\
\text { interval } \\
\text { (ft) }\end{array}$ & $\begin{array}{c}\text { Boosters } \\
\text { used }\end{array}$ & $\begin{array}{c}\text { Blasting } \\
\text { agent } \\
\text { (lbs) }\end{array}$ & $\begin{array}{c}\text { Loaded } \\
\text { by } \\
\text { pump } \\
\text { truck }\end{array}$ & $\begin{array}{c}\text { Chubs } \\
\text { used }\end{array}$ & 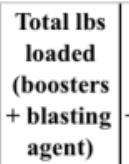 & 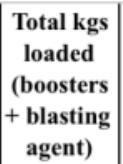 & \begin{tabular}{|c} 
Depth to \\
top of \\
explosives \\
(ft)
\end{tabular} & $\begin{array}{c}\text { Bags of } \\
\text { bentonite } \\
\text { used }\end{array}$ & $\begin{array}{l}\text { Depth to } \\
\text { top of } \\
\text { bentonite } \\
\text { (ft) }\end{array}$ & $\begin{array}{c}\text { Depth } \\
\text { to top } \\
\text { gravel } \\
\text { (ft) }\end{array}$ & $\begin{array}{c}\text { Depth to } \\
\text { water } \\
\text { (ft) }\end{array}$ & $\begin{array}{c}\text { Loading } \\
\text { date } \\
(2011)\end{array}$ \\
\hline \multirow{3}{*}{10000} & $1000 \mathrm{~d} 1$ & 133 & 133 & 6 & 44 & 144 & $y$ & 10.00 & 8 & 1050 & $y$ & & 1058 & 480 & 57 & 4 & 43 & 1.5 & top & 19-Feb \\
\hline & $1000 \mathrm{~d} 2$ & 132 & 132 & 6 & 34 & 142 & $y$ & 10.00 & 8 & 1050 & $y$ & & 1058 & 480 & 56 & 4 & 42 & 2 & top & 19-Feb \\
\hline & $1000 \mathrm{~d} 3$ & 132 & 132 & 6 & 14 & 142 & $\mathrm{y}$ & 10.00 & 8 & 1050 & $y$ & & 1058 & 480 & 59 & 4 & 44 & 2.5 & top & 19-Feb \\
\hline \multirow{2}{*}{10460} & 1046a1 & 122 & 122 & 8 & 22 & 144 & $\mathrm{y}$ & 10.00 & 7 & 1500 & $y$ & & 1507 & 684 & 57 & 4 & 48 & 2 & top & 11-Feb \\
\hline & $1046 \mathrm{a} 2$ & 121 & 121 & 8 & 4 & 143 & $\mathrm{y}$ & 10.00 & 7 & 1500 & $y$ & & 1507 & 684 & 66 & 4 & 56 & 2 & top & 11-Feb \\
\hline 10510 & 1051a & 82.5 & 82.5 & 8 & 14 & 92.5 & & 6.00 & 4 & 500 & $\mathrm{y}$ & & 504 & 229 & 62 & 3 & 60 & 3 & top & 10-Feb \\
\hline 10580 & $1058 \mathrm{c}$ & 83 & 83 & 8 & top & 95 & $\mathrm{y}$ & 8.00 & 4 & 500 & $y$ & & 504 & 229 & 58 & 3 & 53 & 1.5 & top & 11-Feb \\
\hline \multirow{2}{*}{10670} & $1067 \mathrm{al}$ & 83.5 & 83.5 & 8 & 20 & 90 & & 8,4 & 5 & 500 & $\mathrm{y}$ & & 505 & 229 & 63 & & 53.5 & & & 15-Jan \\
\hline & $1067 \mathrm{a} 2$ & 83.5 & 83.5 & 8 & 21.5 & 90 & & 8.00 & 4 & 500 & $\mathrm{y}$ & & 504 & 229 & 58 & & 52.5 & & & 15-Jan \\
\hline 10770 & $1077 \mathrm{a}$ & 78.3 & 78.3 & 6 & 23 & 88 & & 3.20 & 5 & 225 & $\mathrm{n}$ & 9 & 230 & 104 & 52.5 & & 44 & 1.5 & $8-9$ & 13-Jan \\
\hline 10790 & $1079 \mathrm{a}$ & 82 & 82 & 6 & 17.5 & 92 & & 3.00 & 3 & 150 & $\mathrm{n}$ & 6 & 153 & 69 & 67 & & 59.5 & 1.5 & 6.5 & 14-Jan \\
\hline 10810 & $1081 \mathrm{~b}$ & 83 & 83 & 6 & 1 & 95 & $\mathrm{y}$ & 6.00 & 4 & 250 & $y$ & & 254 & 115 & 66 & 2 & 61 & 2.5 & top & 11-Feb \\
\hline 10830 & $1083 \mathrm{~b}$ & 79 & 79 & 6 & 4 & 121 & & 6.00 & 4 & 250 & $y$ & & 254 & 115 & 61 & & 53.5 & & 3.5 & 17-Jan \\
\hline 10870 & $1087 \mathrm{c}$ & 82.5 & 82.5 & 6 & 3 & 94 & $y$ & 6.00 & 4 & 250 & $y$ & & 254 & 115 & 64.5 & 2 & 57.5 & 2 & top & $21-\mathrm{Feb}$ \\
\hline 10900 & $1090 \mathrm{~b}$ & 78 & 78 & 6 & 15 & 88 & & 6,5 & 4 & 250 & $\mathrm{y}$ & & 254 & 115 & 61 & 2 & 54 & 2 & top & 23-Jan \\
\hline 10931 & 1093al & 85 & 85 & 8 & top & 95 & & 8.00 & 4 & 500 & $\mathrm{y}$ & & 504 & 229 & 60 & & 55 & 2 & top & 18-Jan \\
\hline 10932 & $1093 \mathrm{a} 2$ & 85 & 85 & 8 & 15.5 & 95 & & 8.00 & 4 & 500 & $\mathrm{y}$ & & 504 & 229 & 61.5 & & 56 & & top & 18-Jan \\
\hline 10950 & $1095 \mathrm{a}$ & 79 & 79 & 6 & 8 & 89 & & 6.00 & 4 & 250 & $y$ & & 254 & 115 & 61.5 & 2 & 53.5 & & 3.5 & 21-Jan \\
\hline 10980 & 1098a & 78.5 & 78.5 & 6 & 10 & 89 & & 6,5 & 4 & 250 & $\mathrm{y}$ & & 254 & 115 & 57 & 2 & 49.5 & & 2 & 21-Jan \\
\hline 10990 & $1099 \mathrm{c}$ & 79 & 79 & 6 & 25 & 89 & & 6,4 & 4 & 250 & $y$ & & 254 & 115 & 59 & 2 & 53 & & 3 & 18-Jan \\
\hline 11000 & $1100 \mathrm{~b}$ & 71 & 71 & 6 & 10 & 81 & & 6,4 & 4 & 250 & $y$ & & 254 & 115 & 44 & & 32 & 4 & & 18-Jan \\
\hline 11020 & $1102 \mathrm{~b}$ & 80 & 80 & 6 & 36 & 90 & & 6,4 & 4 & 250 & $y$ & & 254 & 115 & 61 & & 53.5 & & 14 & 19-Jan \\
\hline 11030 & 1103a & 87 & 87 & 6 & 17 & 97 & & 6,4 & 4 & 250 & $\mathrm{y}$ & & 254 & 115 & 68 & & 62 & & top & 19-Jan \\
\hline 11050 & $1105 \mathrm{a}$ & 81 & 81 & 6 & 13 & 91 & & $\mathrm{n} / \mathrm{a}$ & 1 & 25 & $\mathrm{n}$ & 1 & 26 & 12 & 80 & & 72 & 12 & & 3-Mar \\
\hline 11100 & $1110 \mathrm{c}$ & 75 & 75 & 8 & 10 & 85 & & 3.80 & 8 & 400 & $\mathrm{n}$ & 16 & 408 & 185 & 48 & 4 & 38 & top & & 6-Mar \\
\hline 11620 & $1162 \mathrm{a}$ & 101.5 & 101.5 & 8 & top & 111.5 & & 2.97 & 18 & 900 & $\mathrm{n}$ & 36 & 918 & 416 & 51 & 4 & 41 & 1 & top & 24-Feb \\
\hline 11680 & $1168 \mathrm{a}$ & 81 & 81 & 6 & 18 & 87 & & 4.90 & 6 & 250 & $\mathrm{n}$ & 10 & 256 & 116 & 56.5 & 2 & 50 & & top & $27-\mathrm{Feb}$ \\
\hline
\end{tabular}




\section{Land Shot Drilling, Loading, and Shooting}

\section{Shot hole description}

(See appendix I for drilling logs and appendix II for drill sample inventory.)

SSIP shots were explosions detonated at the bottoms of drill holes measuring either $15 \mathrm{~cm}$ (6 in.) or $20 \mathrm{~cm}$ (8 in.) in diameter and more than $18 \mathrm{~m}$ (60 ft) deep (fig. 7). The shot holes were drilled by a commercial water-well-drilling rig and cased as needed with steel pipe. At all sites underlain by unconsolidated sedimentary deposits, the holes were fully cased with sealed caps at the bottom. The explosives used were commercial ammonium-nitrate-based product (blasting agent) and typically were pumped into the drill hole by a contracted pump truck (fig. 8). Where access by the pump truck was not possible, the explosives were loaded into shot holes in "chubs," which were nylon bags

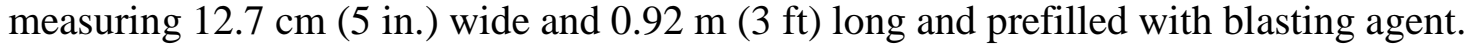

The target depth of each drill hole depended on the proposed charge size, according to the approximate formulas:

1. For 15-cm (6 in.) diameter shot holes:

Target hole depth $(\mathrm{m})=18 \mathrm{~m}+$ shot size $(\mathrm{kg}) /(20.9 \mathrm{~kg} / \mathrm{m})$

(Or, target hole depth $(\mathrm{ft})=60 \mathrm{ft}+$ shot size $(\mathrm{lbs}) /(14 \mathrm{lbs} / \mathrm{ft})$ )

2. For $20-\mathrm{cm}$ (8 in.) diameter shot holes:

Target hole depth $(\mathrm{m})=18 \mathrm{~m}+$ shot size $(\mathrm{kg}) /(37.3 \mathrm{~kg} / \mathrm{m})$

(Or, target hole depth $(\mathrm{ft})=60 \mathrm{ft}+$ shot size $(\mathrm{lbs}) /(25 \mathrm{lbs} / \mathrm{ft})$ )

However, at each shot point, the actual shot size was limited by the shot hole's proximity to man-made structures.

Shot holes were drilled and cased as shown in figures $7 a$ and $7 b$, in soft sediment and in hard rock, respectively. In the case of shot holes in sediments, the holes were cased to the bottom and capped in order to prevent collapse or infilling by mobile clays. The casings were filled with clean water to prevent them from rising buoyantly to the surface. For these locations, we were not able to obtain an accurate measurement of the depth to the water table upon drilling or loading the shot hole. In the case of shot holes in hard bedrock, the holes were cased only in the upper $2-5 \mathrm{~m}$, as needed, to prevent collapse of soil and weathered rock into the open hole, as well as to facilitate loading.

During drilling, loading, shooting, and cleanup, USGS personnel used handheld Garmin GPS units (model GPSMAP 60CSx) in order to survey and locate shot holes. Details and notes were recorded on standardized forms for drilling (fig. 9), loading (fig. 10), and shooting (fig. 11). Cleanup records also were kept. See appendix I for completed drilling logs for all shot holes. An inventory of drill samples taken in each shot hole is given in appendix II. 


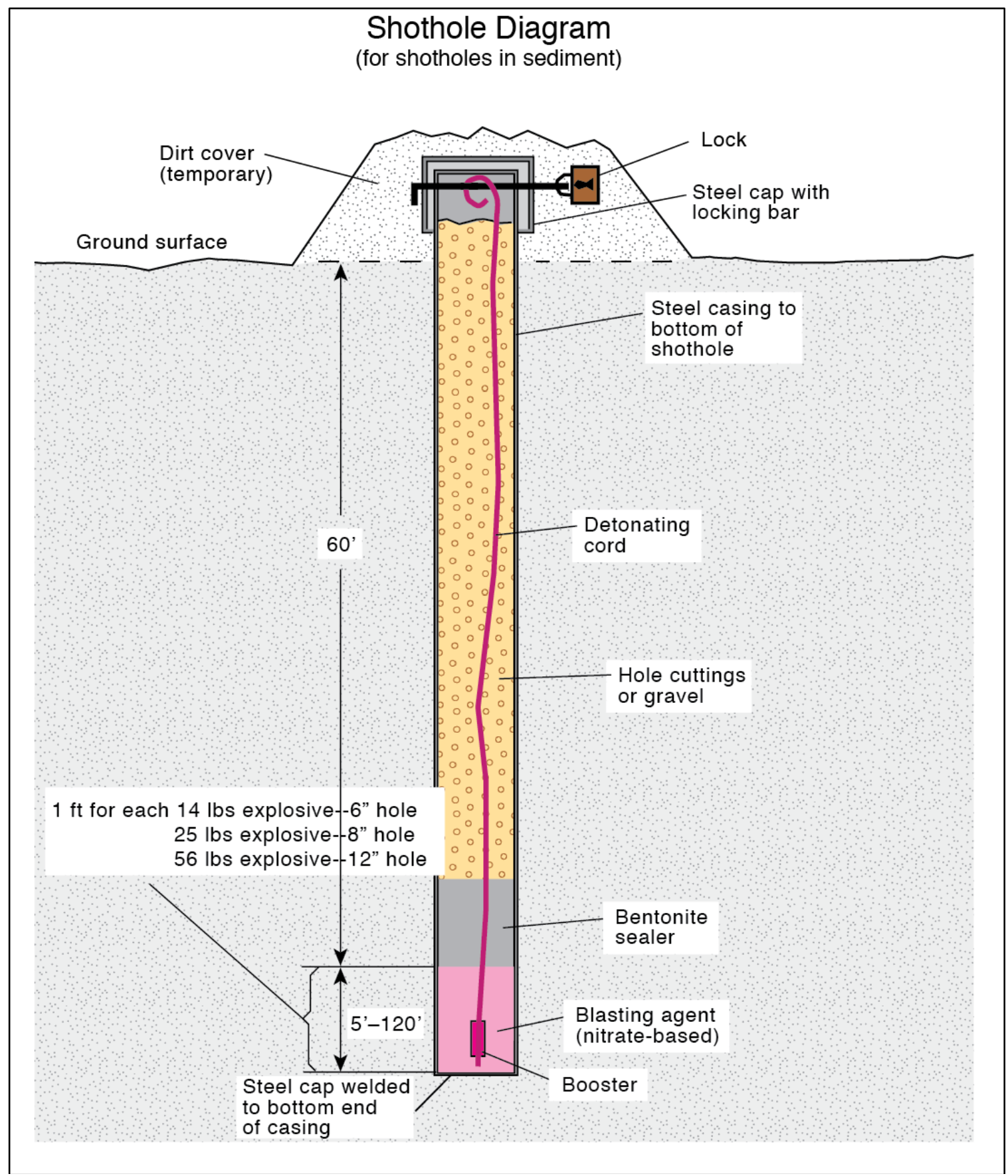

Figure 7a. Cross-sectional diagram of shot holes drilled into soft sediment. Note that in sediment, steel casing is installed for the entire depth, with a steel cap welded to the bottom. 


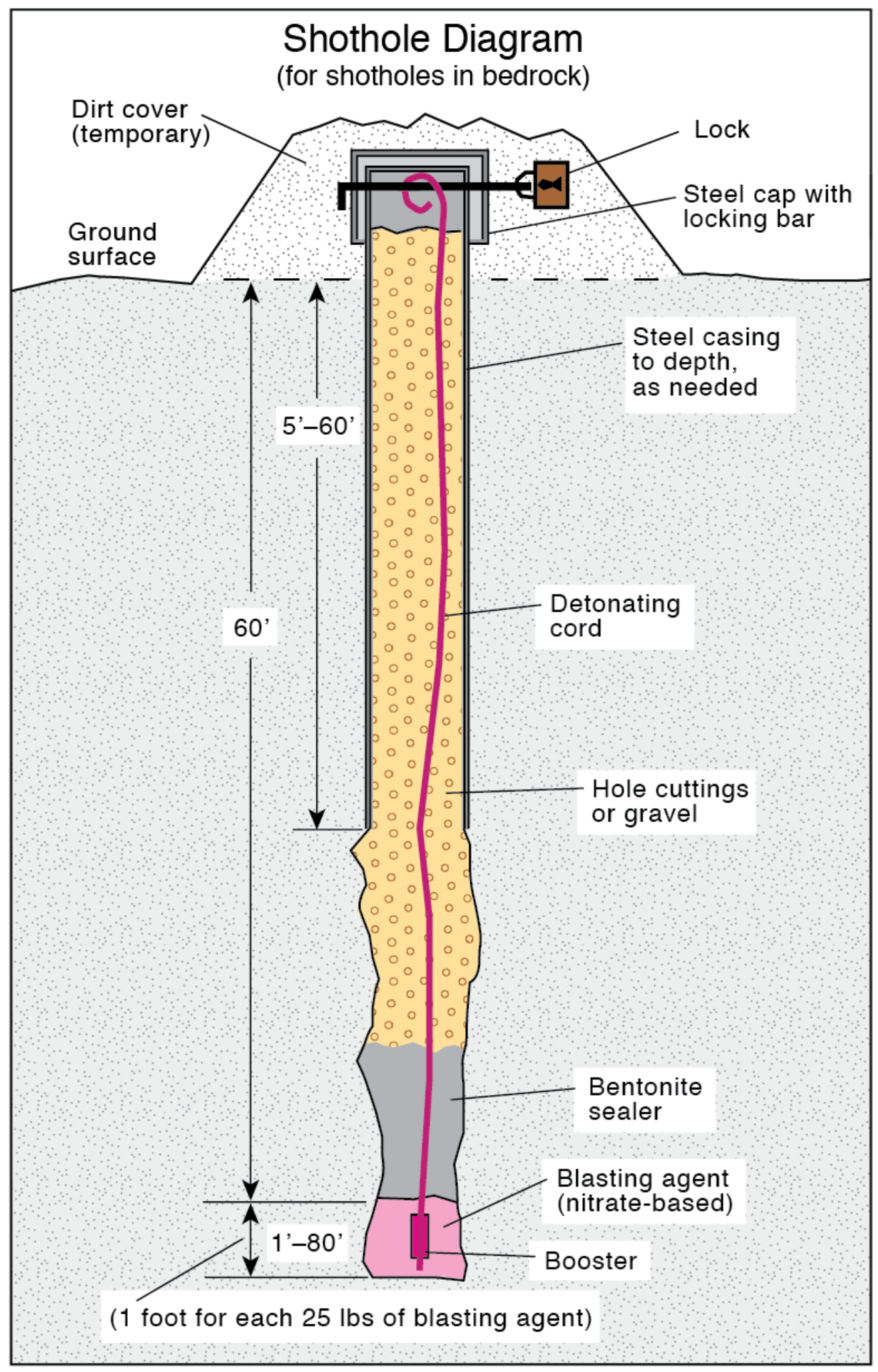

Figure 7b. Cross-sectional diagram of shot holes drilled into hard rock. Note that steel casing is installed only to a depth required to prevent infill from unconsolidated rock or dirt at the ground surface. 


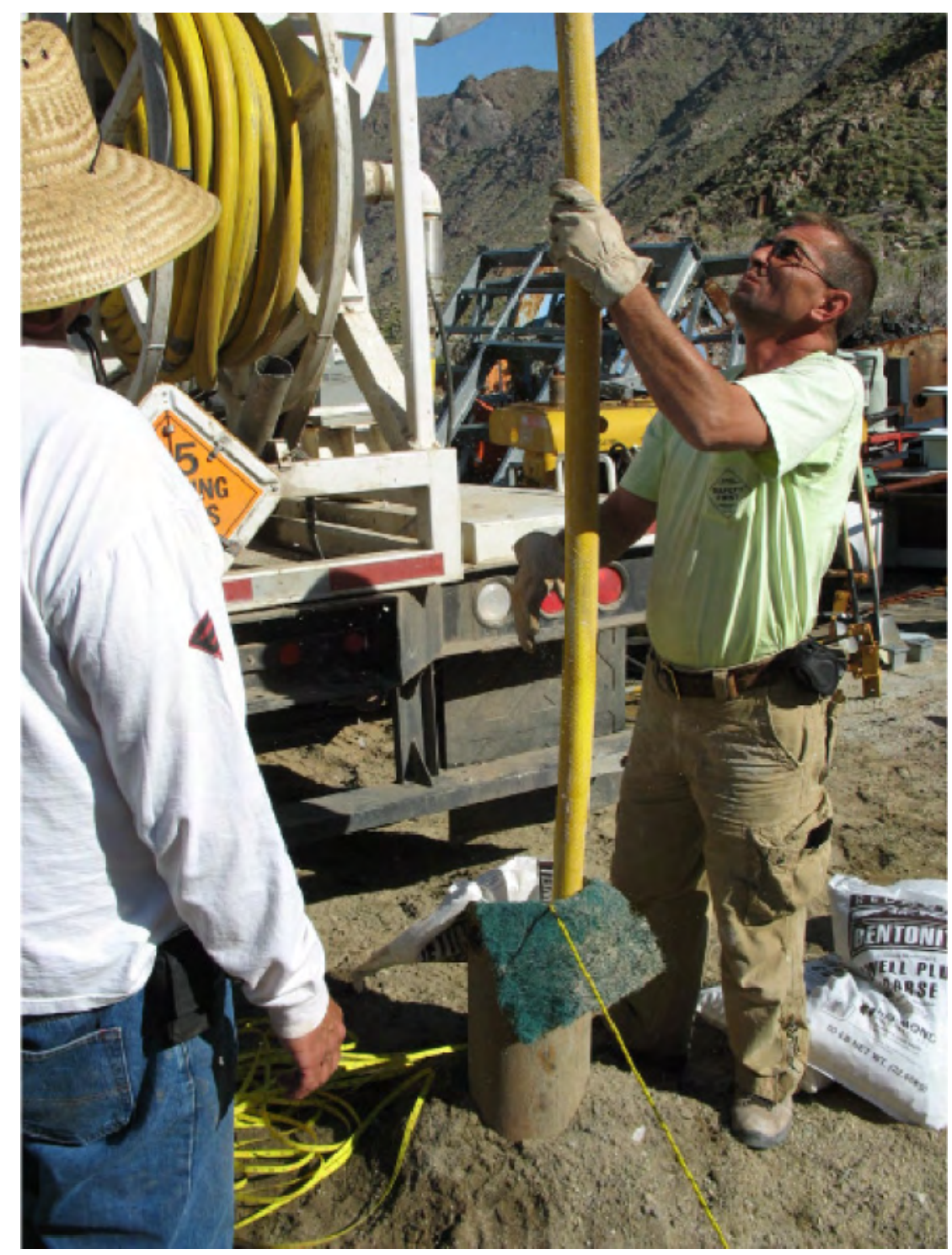

Figure 8. Photograph of U.S. Geological Survey personnel loading blasting agent into shot hole 60000 using the pump truck. The detonating cord (yellow, lower-right corner of photograph) and booster assembly has been lowered to the bottom of the hole. The plastic bentonite bags and green "horse-hair" pad around the top of the steel casing prevents chafing of both the hose and the detonating cord against the coarsely cut metal. 


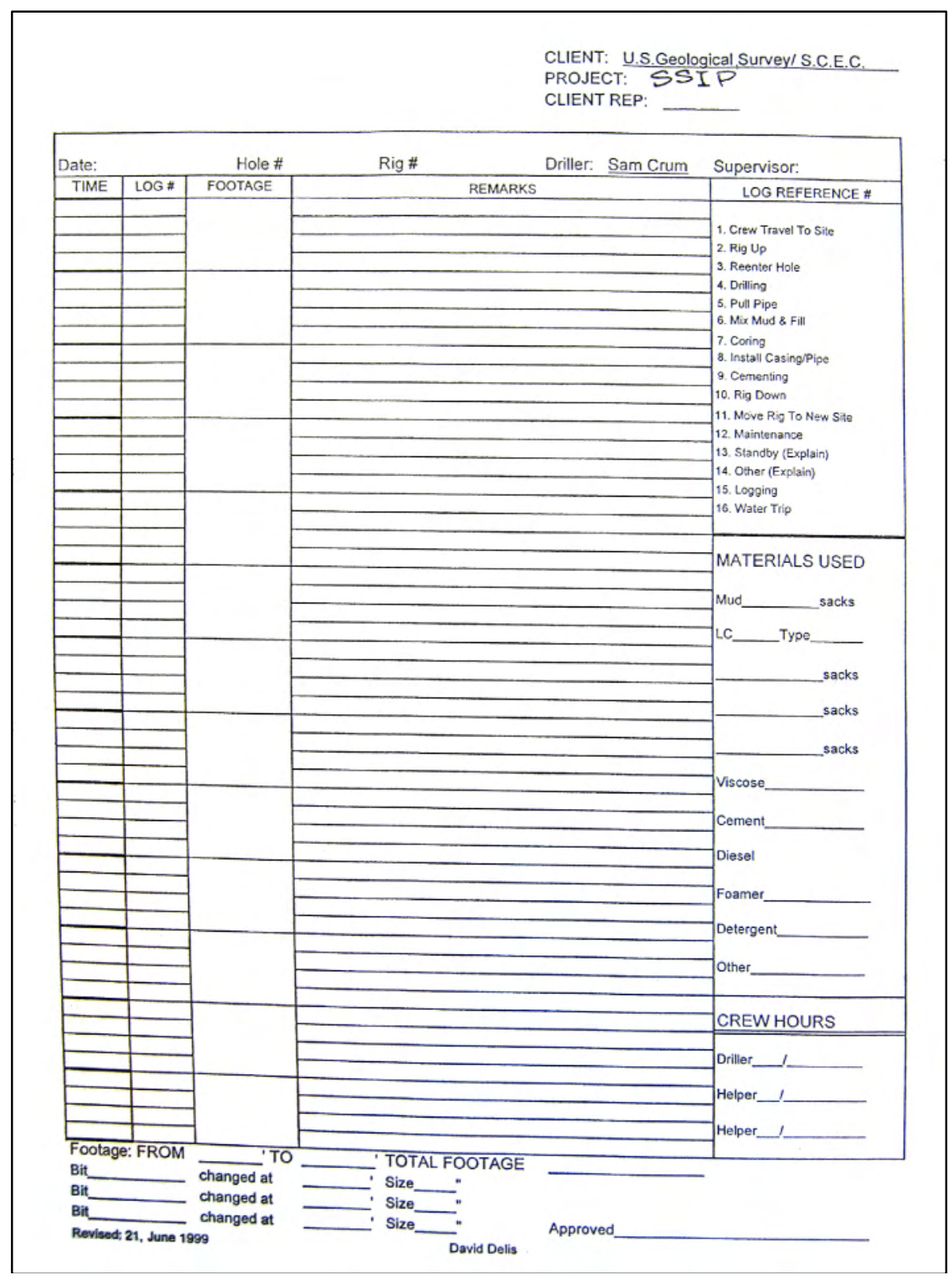

Figure 9. Blank drilling log sheet used by drill watchers for the Salton Seismic Imaging Project. 


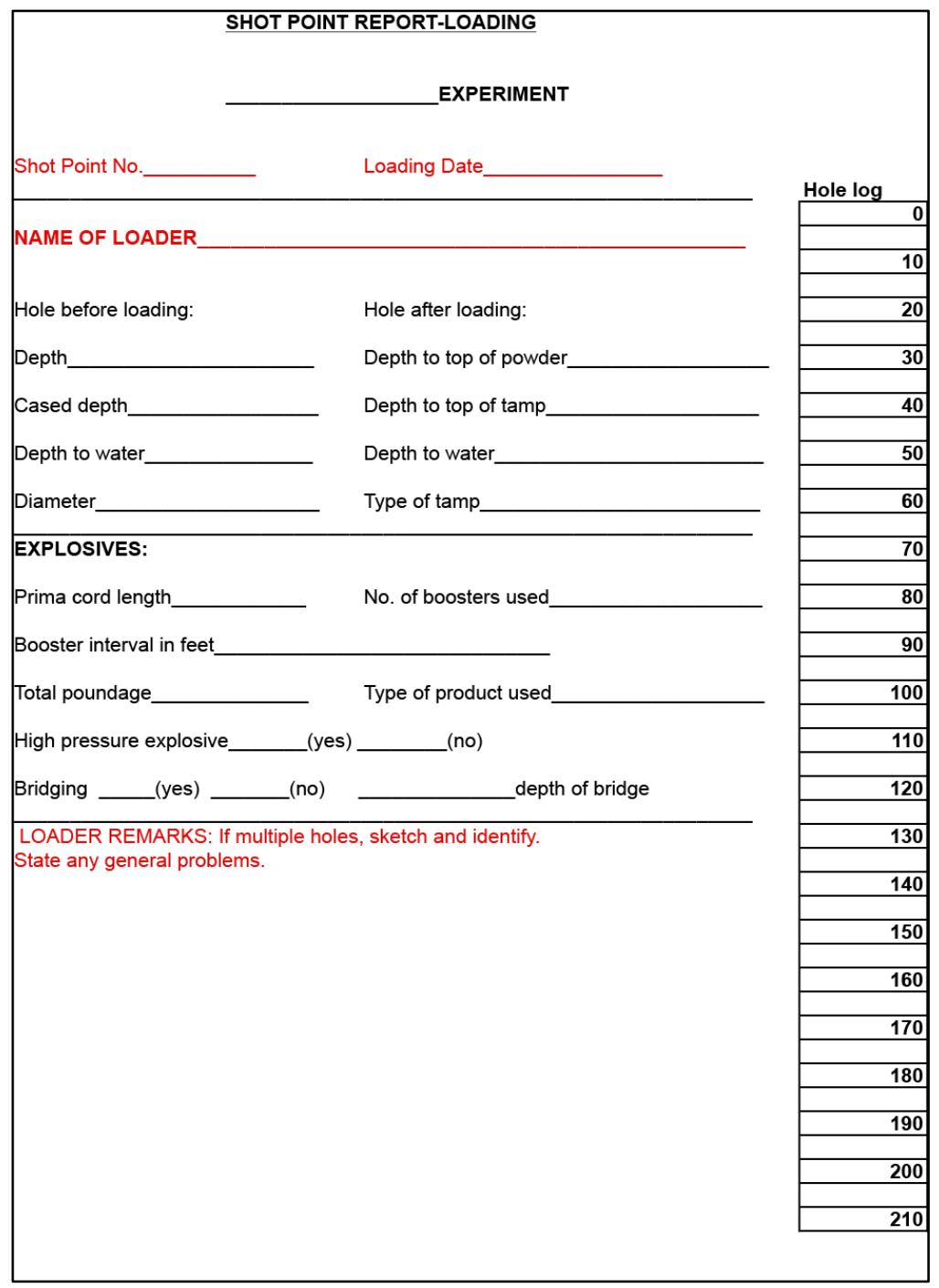

Figure 10. Blank loading log sheet. 
Salton Seismic Imaging Project

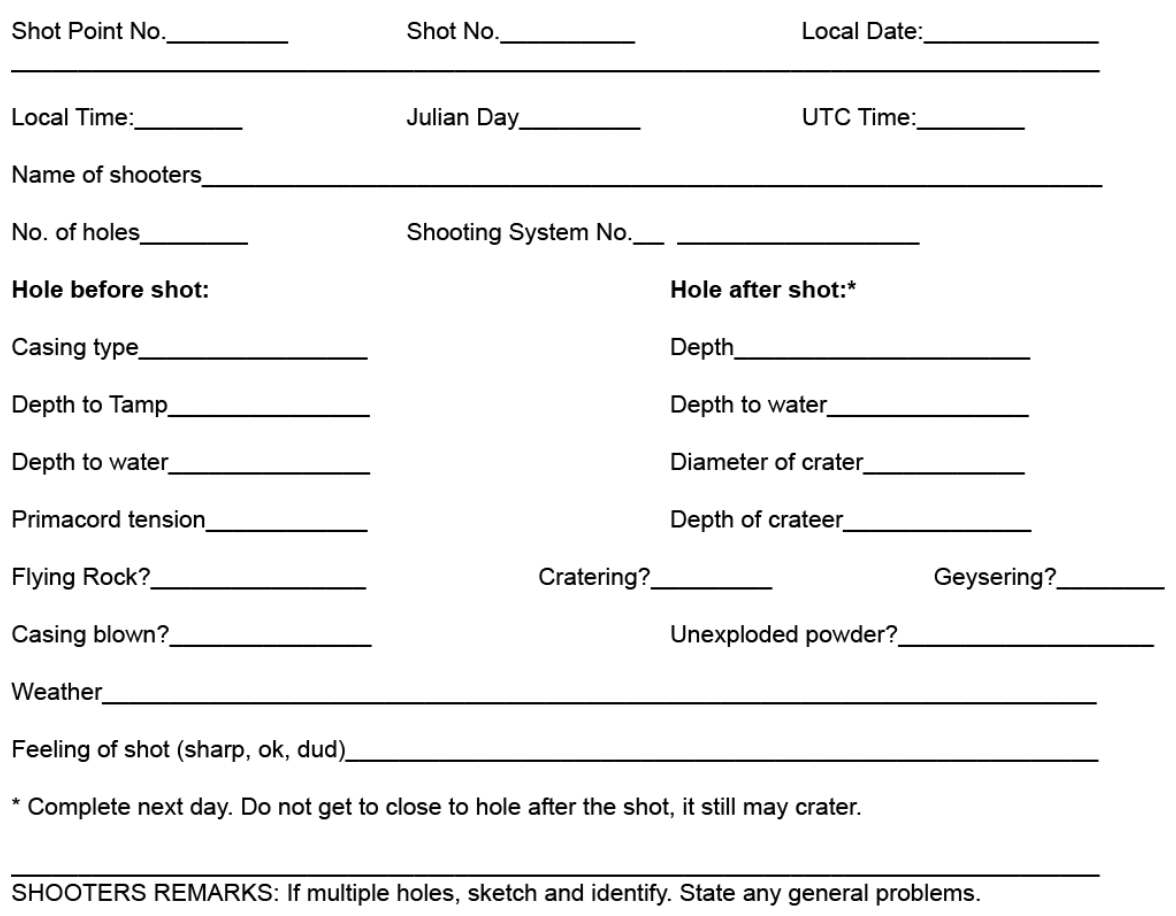

Figure 11. Blank shooting log sheet.

\section{Loading procedures}

(See appendix VIII for loading details for all shot holes; a subset of shots is shown in table 3.)

Loading was accomplished as follows:

1. Upon arrival at the site, loaders unlocked the well cap and noted anything unexpected at the site.

2. Total hole depth and depth to water were measured and recorded (during drilling, fully cased and bottom-capped shot holes were left full of water to within a few feet of the surface).

3. A length of detonating cord was spooled and cut to a length slightly longer (approximately $3 \mathrm{~m}$ (10 ft) longer) than the measured hole depth. The cut ends of the detonating cord were sealed with liquid electrical tape to prevent wicking of water into the ends of the cord.

4. Boosters were threaded onto the detonating cord and taped at intervals along the length of the cord to be submersed by the blasting agent (fig. 12). For 114-228$\mathrm{kg}(250-500 \mathrm{lb})$ shots, in $15 \mathrm{~cm}$ (6 in.) diameter boreholes, boosters were spaced $1.2-1.8 \mathrm{~m}$ (4-6 ft) apart on average. For 455-910 kg (1,000-2,000 lb) shots, in 20

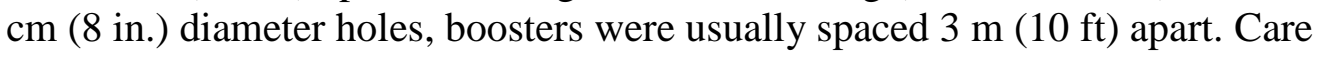
was taken to ensure that one booster was near the bottom of the string and that another was located about $60 \mathrm{~cm}(2 \mathrm{ft}$ ) below the top of the powder column, which was around $18 \mathrm{~m}$ (60 ft) depth below the surface. Most of these detonating 
cord/booster assemblies were bottom-weighted by a brick (fig. 12), in order to ensure that the assemblies did not buoyantly rise while the blasting agent was pumped into the holes.

5. The required amount of blasting agent was pumped from the pump truck into the shot hole using a hose lowered to near the bottom of the hole (fig. 8). The hose

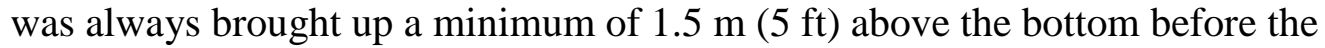
start of pumping; in an attempt to avoid floating of nonweighted booster/detonation-cord assemblies upward from the bottom once pumping began. The hose would be slowly drawn upward during the pumping process. The blasting agent displaced some of the standing water out of the hole.

6. Two 23-kg (50-lb) bags of $10-\mathrm{mm}$ (3/8-in.) bentonite pellets were slowly poured through the water column onto the top of the blasting agent, at $18 \mathrm{~m}(60 \mathrm{ft})$ depth, to separate the blasting agent from the fill gravel ("tamp") to be loaded in the next step.

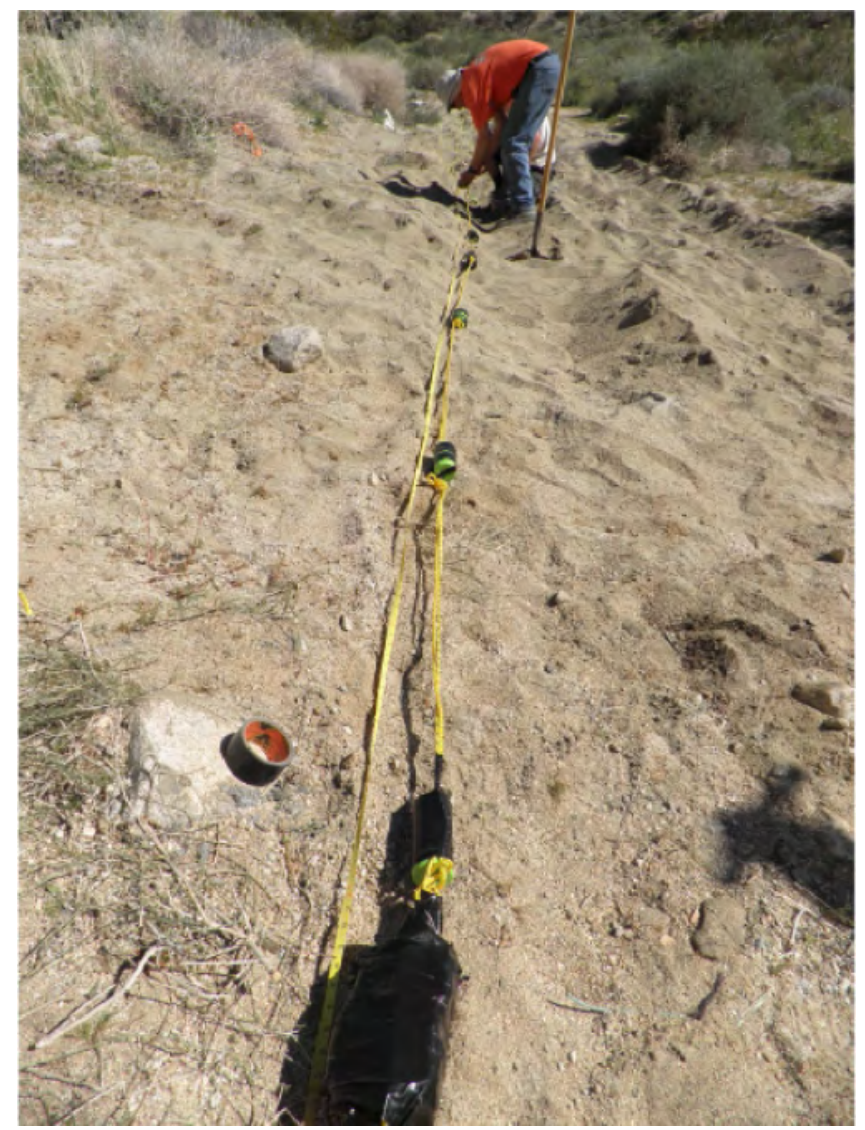

Figure 12. Photograph of detonating cord and booster assembly. Boosters (green cylinders) were threaded onto and taped securely to the detonating cord (yellow) at fixed intervals (measuring tape shown on left side of the assembly). A brick (or rock), seen at the bottom of the photograph, was taped onto the bottom of the assembly to prevent assembly from floating upward during pumping of blasting agent into the shot hole. 
7. Washed, approximately 10-13 mm (3/8-1/2 in.) diameter gravel was slowly

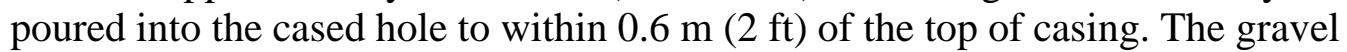
displaced much of the water that had filled the casing. Clean gravel was used in all cases, because both drill cuttings and unwashed gravel contain silt and clay, which would increase the density and viscosity of the borehole water. Dirty water could prevent rapid sinking of the gravel to the bottom of the tamp column, and silt, clay, and gravel can bind together to form interlocking clumps ("bridges”). A bridge formed within a column of tamp leaves a water-filled pocket above the explosive, which reduces the tamp's effectiveness. Care also was taken in filling dry holes, whereby holes were loaded slowly to ensure that no bridges were formed.

8. The detonating cord was then wrapped around a welded ring on the underside of a custom-made casing cap. The cap was gently placed on the top of the casing while personnel made sure that the detonating cord was not pinched under the cap. Any water in the uppermost 30-60 cm (1-2 ft) of the shot hole was bailed out prior to capping, in order to prevent water from wicking into the detonating cord.

9. A locking bar was gently inserted (so as to not pinch the detonating cord) through aligned holes in both the casing and the cap, and a heavy padlock was locked onto the end of the bar (fig. 7).

10. Where the cap and casing were at grade, they were covered with a small piece of plywood and a pile of dirt to disguise the site. Where the cap and casing were above grade, they were covered with a tarp or sheet of plastic, which was then covered with dirt and brush to disguise the site.

\section{Shooting Procedures}

(See tables 4 and 5 for shooting times, locations, and other details.)

Shooting was performed by U.S. government employees. The shots were detonated at night when wind and cultural noise at our seismometer sites were expected to be lowest (normally 0700 to 1200 UTC, or 11 p.m. to 4 a.m. Pacific Standard (local) Time). Shot times on Line 7 were further modified to avoid the presence of freight trains within $3 \mathrm{mi}$ of the line. Train observers, in radio contact with the shooters, stood watch 3 mi northwest and $3 \mathrm{mi}$ southeast of the point where Line 7 crossed the train tracks (Line 7 was laid out along or near an abandoned railroad track that diverges to the northeast from the contemporary track along the northeastern shore of the Salton Sea.)

Shooting procedures were as follows: shooters were assigned to teams and given a master shot schedule the day before, or the day of their scheduled shots. At least one shooting team member scouted their assigned shot points from a few hours to as much a 1 day prior to shot time. There were as many as six teams per shooting night, with each team being responsible for one to five shots. To ensure that set-up would occur in a safe and timely manner, each shooting team arrived at their first assigned shot point from 30 to 60 min prior to shot time. At each shot site, the area was secured, the casing cap removed, the shot line laid out to $150 \mathrm{~m}$ (500 ft) away from (and upwind of) the shot point, and the shooting system started so that the internal clock could be synchronized to a GPS time signal before the scheduled shot time. The shooting systems were of new design, built specially for the SSIP (fig. 13). Approximately 5 min prior to the assigned 
Table 4. Land shot times and locations ("shot list") for all shots from the Salton Seismic Imaging Project.

[Horizontal coordinate information is referenced to the World Geodetic System of 1984 (WGS84) datum. Vertical coordinate information (elevation) was obtained from Google Earth, which uses elevation data from the National Aeronautics and Space Administration's (NASA's) Shuttle Radar Topography Mission (Farr and others, 2007). Elevations for shotpoints from Google Earth agree well (within a meter or so) with elevations of nearby land receivers, which were obtained using hand-held global positioning system (GPS) receivers (see text) referenced to the WGS84 EGM96 geoid]

\begin{tabular}{|c|c|c|c|c|c|c|c|c|c|c|c|c|c|}
\hline $\begin{array}{l}\text { Shot } \\
\text { point ID } \\
\text { (final) }\end{array}$ & $\begin{array}{l}\text { Shot point } \\
\text { ID } \\
\text { (original) }\end{array}$ & $\begin{array}{l}\text { Latitude } \\
\text { (WGS 84) }\end{array}$ & $\begin{array}{l}\text { Longitude } \\
\text { (WGS 84) }\end{array}$ & $\begin{array}{l}\text { Elevation } \\
\qquad(\mathrm{m})\end{array}$ & Year & $\begin{array}{l}\text { Shot } \\
\text { date } \\
\text { (Julian } \\
\text { day) }\end{array}$ & $\begin{array}{l}\text { Shot } \\
\text { time } \\
\text { (UTC) }\end{array}$ & $\begin{array}{l}\text { Depth to } \\
\text { center of } \\
\text { charge } \\
\text { (ft) }\end{array}$ & $\begin{array}{l}\text { Depth to } \\
\text { center of } \\
\text { charge } \\
\text { (m) }\end{array}$ & $\begin{array}{l}\text { Depth to } \\
\text { top of } \\
\text { charge } \\
\text { (m) }\end{array}$ & $\begin{array}{l}\text { Total } \\
\text { hole } \\
\text { depth } \\
(\mathrm{m})\end{array}$ & $\begin{array}{c}\text { Explosives } \\
\text { loaded } \\
(\mathrm{kg})\end{array}$ & $\begin{array}{l}\text { Colocated } \\
\text { field shot } \\
\text { point } \\
\text { name }\end{array}$ \\
\hline 10000 & $\begin{array}{c}\text { 1000d1, d2, } \\
\text { d3 }\end{array}$ & 32.48060527 & -114.7377943 & 44 & 2011 & 65 & $7: 42$ & 94.8 & 28.9 & 17.5 & 40.3 & 1440 & \\
\hline 10460 & 1046a1 \& a2 & 32.69438 & -115.25193 & 44 & 2011 & 65 & 12:09 & 91.5 & 27.9 & 18.7 & 37.0 & 1367 & \\
\hline 10510 & $1051 \mathrm{a}$ & 32.7319999 & -115.27624 & 45 & 2011 & 63 & $7: 12$ & 72.3 & 22.0 & 18.9 & 25.1 & 229 & \\
\hline 10580 & $1058 \mathrm{c}$ & 32.78048 & -115.3244 & -7 & 2011 & 63 & $8: 12$ & 70.5 & 21.5 & 17.7 & 25.3 & 229 & \\
\hline 10670 & 1067a1 \& a2 & 32.84924 & -115.3718 & -3 & 2011 & 65 & $10: 12$ & 72.0 & 21.9 & 18.4 & 25.5 & 458 & \\
\hline 10770 & $1077 \mathrm{a}$ & 32.9235268 & -115.4362981 & -38 & 2011 & 63 & $9: 12$ & 65.4 & 19.9 & 16.0 & 23.9 & 104 & \\
\hline 10790 & 1079a & 32.9379852 & -115.4486799 & -41 & 2011 & 63 & $10: 12$ & 74.5 & 22.7 & 20.4 & 25.0 & 69 & \\
\hline 10810 & $1081 b$ & 32.95309 & -115.46327 & -40 & 2011 & 63 & 7:03 & 74.5 & 22.7 & 20.1 & 25.3 & 115 & \\
\hline 10830 & $1083 b$ & 32.9638334 & -115.4648641 & -44 & 2011 & 63 & 8:03 & 70.0 & 21.3 & 18.6 & 24.1 & 115 & \\
\hline 10870 & $1087 \mathrm{c}$ & 33.00037 & -115.50157 & -60 & 2011 & 146 & 3:09 & 73.5 & 22.4 & 19.7 & 25.1 & 115 & \\
\hline 10900 & 1090b & 33.0131825 & -115.5136409 & -48 & 2011 & 63 & 10:03 & 69.5 & 21.2 & 18.6 & 23.8 & 115 & \\
\hline 10931 & 1093a1 & 33.0400768 & -115.5238794 & -59 & 2011 & 65 & $11: 15$ & 72.5 & 22.1 & 18.3 & 25.9 & 229 & \\
\hline 10932 & 1093a2 & 33.0400515 & -115.5238566 & -43 & 2011 & 65 & 12:15 & 73.3 & 22.3 & 18.7 & 25.9 & 229 & \\
\hline 10950 & 1095a & 33.0527652 & -115.5362777 & -60 & 2011 & 63 & 11:03 & 70.3 & 21.4 & 18.7 & 24.1 & 115 & \\
\hline 10980 & 1098a & 33.0796277 & -115.5519003 & -62 & 2011 & 63 & 8:06 & 67.8 & 20.7 & 17.4 & 23.9 & 115 & \\
\hline 10990 & 1099c & 33.0891294 & -115.5729372 & -70 & 2011 & 63 & 9:06 & 69.0 & 21.0 & 18.0 & 24.1 & 115 & \\
\hline 11000 & $1100 \mathrm{~b}$ & 33.0967181 & -115.574467 & -62 & 2011 & 63 & 10:06 & 57.5 & 17.5 & 13.4 & 21.6 & 115 & \\
\hline 11020 & $1102 b$ & 33.1045347 & -115.5927187 & -66 & 2011 & 63 & 11:06 & 70.5 & 21.5 & 18.6 & 24.4 & 115 & \\
\hline
\end{tabular}




\begin{tabular}{|c|c|c|c|c|c|c|c|c|c|c|c|c|c|}
\hline $\begin{array}{l}\text { Shot } \\
\text { point ID } \\
\text { (final) }\end{array}$ & $\begin{array}{c}\text { Shot point } \\
\text { ID } \\
\text { (original) }\end{array}$ & $\begin{array}{l}\text { Latitude } \\
\text { (WGS 84) }\end{array}$ & $\begin{array}{l}\text { Longitude } \\
\text { (WGS 84) }\end{array}$ & $\begin{array}{l}\text { Elevation } \\
\qquad(\mathrm{m})\end{array}$ & Year & $\begin{array}{l}\text { Shot } \\
\text { date } \\
\text { (Julian } \\
\text { day) }\end{array}$ & $\begin{array}{l}\text { Shot } \\
\text { time } \\
\text { (UTC) }\end{array}$ & $\begin{array}{l}\text { Depth to } \\
\text { center of } \\
\text { charge } \\
\text { (ft) }\end{array}$ & $\begin{array}{l}\text { Depth to } \\
\text { center of } \\
\text { charge } \\
\text { (m) }\end{array}$ & $\begin{array}{l}\text { Depth to } \\
\text { top of } \\
\text { charge } \\
\text { (m) }\end{array}$ & $\begin{array}{l}\text { Total } \\
\text { hole } \\
\text { depth } \\
\text { (m) }\end{array}$ & $\begin{array}{c}\text { Explosives } \\
\text { loaded } \\
(\mathrm{kg})\end{array}$ & $\begin{array}{c}\text { Colocated } \\
\text { field shot } \\
\text { point } \\
\text { name }\end{array}$ \\
\hline 11030 & $1103 a$ & 33.1182575 & -115.5877658 & -69 & 2011 & 63 & $11: 09$ & 77.5 & 23.6 & 20.7 & 26.5 & 115 & \\
\hline 11050 & $1105 a$ & 33.1256888 & -115.5975711 & -64 & 2011 & 63 & $10: 39$ & 80.5 & 24.5 & 24.4 & 24.7 & 12 & \\
\hline 11100 & $1110 \mathrm{c}$ & 33.1708781 & -115.6371253 & -49 & 2011 & 66 & $7: 12$ & 61.5 & 18.7 & 14.6 & 22.9 & 185 & \\
\hline 11620 & $1162 \mathrm{a}$ & 33.514942 & -116.0702179 & -84 & 2011 & 66 & $8: 33$ & 76.3 & 23.2 & 15.5 & 30.9 & 416 & \\
\hline 11680 & $1168 \mathrm{a}$ & 33.5641732 & -116.1147066 & -71 & 2011 & 68 & $8: 18$ & 68.8 & 21.0 & 17.2 & 24.7 & 116 & \\
\hline 11800 & $1180 \mathrm{c}$ & 33.6315656 & -116.1904832 & -35 & 2011 & 68 & $9: 18$ & 75.8 & 23.1 & 20.7 & 25.5 & 69 & \\
\hline 11860 & $1186 a$ & 33.6706442 & -116.2288909 & -11 & 2011 & 68 & $10: 48$ & 71.5 & 21.8 & 18.9 & 24.7 & 115 & \\
\hline 11960 & 1196a & 33.7444438 & -116.3019851 & 37 & 2011 & 69 & $7: 18$ & 14.4 & 4.4 & 4.2 & 4.6 & 5 & \\
\hline 12000 & $1200 \mathrm{~b}$ & 33.7798373 & -116.3533524 & 44 & 2011 & 69 & $7: 12$ & 83.3 & 25.4 & 21.3 & 29.4 & 137 & \\
\hline 12050 & $1205 a$ & 33.7976501 & -116.3660993 & 53 & 2011 & 68 & 9:15 & 70.3 & 21.4 & 18.4 & 24.4 & 229 & \\
\hline 12100 & 1210a & 33.8424034 & -116.4047657 & 121 & 2011 & 66 & 9:09 & 79.0 & 24.1 & 17.7 & 30.5 & 456 & \\
\hline 12220 & $1222 \mathrm{a}$ & 33.9194267 & -116.4886295 & 230 & 2011 & 68 & $8: 15$ & 72.5 & 22.1 & 19.2 & 25.0 & 115 & \\
\hline 12300 & $1230 \mathrm{a}$ & 33.9747075 & -116.5397331 & 376 & 2011 & 68 & $7: 15$ & 69.5 & 21.2 & 18.6 & 23.8 & 81 & $6012 a$ \\
\hline 12330 & 1234b2 & 34.0011001 & -116.5570782 & 474 & 2011 & 70 & 8:06 & 71.0 & 21.6 & 18.3 & 25.0 & 230 & \\
\hline 12341 & $1234 \mathrm{c} 1 \& \mathrm{c} 2$ & 34.0086438 & -116.571285 & 563 & 2011 & 66 & $7: 15$ & 94.0 & 28.7 & 20.1 & 37.2 & 1367 & \\
\hline 12342 & 1234c3 & 34.00864 & -116.57123 & 563 & 2011 & 69 & $10: 39$ & 87.0 & 26.5 & 21.0 & 32.0 & 456 & \\
\hline 20000 & 2000h1 & 32.5710427 & -116.8659902 & 704 & 2011 & 65 & 7:03 & 85.5 & 26.1 & 17.4 & 34.7 & 684 & \\
\hline 20220 & 2022a & 32.6008 & -116.68154 & 372 & 2011 & 65 & 9:03 & 105.5 & 32.2 & 23.0 & 41.3 & 684 & \\
\hline 20550 & $2055 b$ & 32.67207 & -116.34656 & 1130 & 2011 & 65 & 10:33 & 101.8 & 31.0 & 18.6 & 43.4 & 911 & \\
\hline 20810 & $2081 b$ & 32.738509 & -116.0447917 & 226 & 2011 & 65 & $11: 36$ & 98.5 & 30.0 & 16.5 & 43.6 & 911 & $3000 x$ \\
\hline 20940 & 2094a & 32.7644505 & -115.9330944 & 82 & 2011 & 62 & $7: 12$ & 74.3 & 22.6 & 20.3 & 25.0 & 115 & \\
\hline 20970 & 2097a & 32.7758476 & -115.9110506 & 59 & 2011 & 62 & $8: 12$ & 74.0 & 22.6 & 20.1 & 25.0 & 115 & \\
\hline 21000 & $2100 c$ & 32.78898 & -115.87748 & 46 & 2011 & 62 & 9:12 & 75.3 & 22.9 & 20.3 & 25.6 & 115 & \\
\hline 21050 & $2105 b$ & 32.7958087 & -115.8349872 & 12 & 2011 & 62 & $10: 12$ & 72.8 & 22.2 & 19.5 & 24.8 & 115 & \\
\hline
\end{tabular}




\begin{tabular}{|c|c|c|c|c|c|c|c|c|c|c|c|c|c|}
\hline $\begin{array}{l}\text { Shot } \\
\text { point ID } \\
\text { (final) }\end{array}$ & $\begin{array}{c}\text { Shot point } \\
\text { ID } \\
\text { (original) }\end{array}$ & $\begin{array}{l}\text { Latitude } \\
\text { (WGS 84) }\end{array}$ & $\begin{array}{l}\text { Longitude } \\
\text { (WGS 84) }\end{array}$ & $\begin{array}{l}\text { Elevation } \\
\quad(\mathrm{m})\end{array}$ & Year & $\begin{array}{l}\text { Shot } \\
\text { date } \\
\text { (Julian } \\
\text { day) }\end{array}$ & $\begin{array}{l}\text { Shot } \\
\text { time } \\
\text { (UTC) }\end{array}$ & $\begin{array}{l}\text { Depth to } \\
\text { center of } \\
\text { charge } \\
\text { (ft) }\end{array}$ & $\begin{array}{l}\text { Depth to } \\
\text { center of } \\
\text { charge } \\
\text { (m) }\end{array}$ & $\begin{array}{l}\text { Depth to } \\
\text { top of } \\
\text { charge } \\
\text { (m) }\end{array}$ & $\begin{array}{l}\text { Total } \\
\text { hole } \\
\text { depth } \\
\text { (m) }\end{array}$ & $\begin{array}{c}\text { Explosives } \\
\text { loaded } \\
(\mathrm{kg})\end{array}$ & $\begin{array}{c}\text { Colocated } \\
\text { field shot } \\
\text { point } \\
\text { name }\end{array}$ \\
\hline 21130 & 2113a & 32.820054 & -115.7417829 & -21 & 2011 & 62 & $10: 03$ & 70.3 & 21.4 & 18.7 & 24.1 & 115 & \\
\hline 21170 & $2117 a$ & 32.833384 & -115.7095724 & -16 & 2011 & 62 & 9:03 & 71.0 & 21.6 & 19.2 & 24.1 & 115 & \\
\hline 21210 & $2121 b$ & 32.8437623 & -115.6635519 & -15 & 2011 & 62 & 8:03 & 73.0 & 22.3 & 19.0 & 25.5 & 102 & \\
\hline 21230 & $2123 b$ & 32.8552248 & -115.6390572 & -19 & 2011 & 62 & 7:03 & 75.5 & 23.0 & 20.4 & 25.6 & 115 & \\
\hline 21250 & $2125 a$ & 32.8524368 & -115.6123974 & -20 & 2011 & 62 & $7: 06$ & 68.8 & 21.0 & 17.4 & 24.5 & 115 & \\
\hline 21330 & 2133a & 32.8851499 & -115.5409971 & -28 & 2011 & 65 & $7: 15$ & 100.0 & 30.5 & 18.0 & 43.0 & 911 & \\
\hline 21340 & $2134 a$ & 32.883911 & -115.5274756 & -46 & 2011 & 62 & 8:06 & 67.3 & 20.5 & 16.8 & 24.2 & 161 & \\
\hline 21360 & $2136 b$ & 32.8871 & -115.51141 & -48 & 2011 & 62 & 9:06 & 70.5 & 21.5 & 17.7 & 25.3 & 116 & \\
\hline 21410 & $2141 \mathrm{a}$ & 32.9024203 & -115.4585248 & -45 & 2011 & 62 & 10:06 & 70.9 & 21.6 & 18.0 & 25.2 & 116 & \\
\hline 21450 & $2145 \mathrm{a}$ & 32.9163439 & -115.4222356 & -28 & 2011 & 62 & 10:39 & 67.8 & 20.7 & 17.1 & 24.2 & 116 & $1075 x$ \\
\hline 21500 & $2150 a$ & 32.9306755 & -115.3699946 & -18 & 2011 & 62 & 9:39 & 63.3 & 19.3 & 14.8 & 23.8 & 127 & \\
\hline 21640 & $2164 a$ & 32.9638338 & -115.2313188 & -1 & 2011 & 65 & 10:09 & 85.0 & 25.9 & 17.7 & 34.1 & 592 & \\
\hline 21790 & $2179 a$ & 33.0051888 & -115.0686688 & 88 & 2011 & 62 & 8:09 & 67.8 & 20.7 & 17.5 & 23.8 & 115 & \\
\hline 21830 & 2183a & 33.0188687 & -115.0357395 & 142 & 2011 & 62 & 7:09 & 68.5 & 20.9 & 18.0 & 23.8 & 115 & \\
\hline 21880 & 2188a & 33.057049 & -114.9896489 & 223 & 2011 & 65 & 9:09 & 97.0 & 29.6 & 22.3 & 36.9 & 911 & \\
\hline 22220 & 2222a1 \& a2 & 33.2163469 & -114.6784117 & 71 & 2011 & 65 & 7:09 & 86.0 & 26.2 & 16.8 & 35.7 & 1368 & \\
\hline 30220 & $3022 \mathrm{a}$ & 32.8858766 & -115.8858378 & 39 & 2011 & 65 & 10:06 & 80.0 & 24.4 & 18.6 & 30.2 & 467 & \\
\hline 30320 & 3032a & 32.9595842 & -115.8168396 & 123 & 2011 & 65 & 8:06 & 81.0 & 24.7 & 17.7 & 31.7 & 479 & \\
\hline 30360 & $3036 \mathrm{a} 2$ & 32.9757261 & -115.8054349 & 61 & 2011 & 65 & $7: 06$ & 70.5 & 21.5 & 18.3 & 24.7 & 229 & \\
\hline 30450 & $3045 b$ & 33.05279 & -115.72717 & -43 & 2011 & 75 & 9:00 & 65.3 & 19.9 & 15.5 & 24.2 & 186 & \\
\hline 30480 & $3048 b$ & 33.0738252 & -115.7080192 & -69 & 2011 & 65 & 9:15 & 64.5 & 19.7 & 16.2 & 23.2 & 229 & \\
\hline 30520 & $3052 b$ & 33.0894646 & -115.6844054 & -59 & 2011 & 63 & 7:06 & 71.8 & 21.9 & 18.9 & 24.8 & 115 & \\
\hline 30540 & $3054 a$ & 33.104858 & -115.6751786 & -78 & 2011 & 75 & 9:03 & 71.9 & 21.9 & 19.4 & 24.5 & 115 & \\
\hline 30560 & $3056 a$ & 33.1187973 & -115.6669644 & -66 & 2011 & 75 & 9:06 & 69.0 & 21.0 & 18.3 & 23.8 & 115 & \\
\hline
\end{tabular}




\begin{tabular}{|c|c|c|c|c|c|c|c|c|c|c|c|c|c|}
\hline $\begin{array}{l}\text { Shot } \\
\text { point ID } \\
\text { (final) }\end{array}$ & $\begin{array}{c}\text { Shot point } \\
\text { ID } \\
\text { (original) }\end{array}$ & $\begin{array}{l}\text { Latitude } \\
\text { (WGS 84) }\end{array}$ & $\begin{array}{l}\text { Longitude } \\
\text { (WGS 84) }\end{array}$ & $\begin{array}{l}\text { Elevation } \\
\text { (m) }\end{array}$ & Year & $\begin{array}{l}\text { Shot } \\
\text { date } \\
\text { (Julian } \\
\text { day) }\end{array}$ & $\begin{array}{l}\text { Shot } \\
\text { time } \\
\text { (UTC) }\end{array}$ & $\begin{array}{l}\text { Depth to } \\
\text { center of } \\
\text { charge } \\
\text { (ft) }\end{array}$ & $\begin{array}{l}\text { Depth to } \\
\text { center of } \\
\text { charge } \\
\text { (m) }\end{array}$ & $\begin{array}{l}\text { Depth to } \\
\text { top of } \\
\text { charge } \\
\text { (m) }\end{array}$ & $\begin{array}{l}\text { Total } \\
\text { hole } \\
\text { depth } \\
\text { (m) }\end{array}$ & $\begin{array}{c}\text { Explosives } \\
\text { loaded } \\
(\mathrm{kg})\end{array}$ & $\begin{array}{c}\text { Colocated } \\
\text { field shot } \\
\text { point } \\
\text { name }\end{array}$ \\
\hline 30580 & 3058a & 33.1329896 & -115.646915 & -74 & 2011 & 75 & $8: 39$ & 70.8 & 21.6 & 18.4 & 24.7 & 115 & \\
\hline 30640 & $3064 b$ & 33.1798624 & -115.6148256 & -70 & 2011 & 146 & 1:01 & 72.0 & 21.9 & 19.2 & 24.7 & 115 & \\
\hline 30670 & $3067 a$ & 33.2056284 & -115.5884343 & -71 & 2011 & 75 & 9:12 & 70.0 & 21.3 & 18.3 & 24.4 & 129 & \\
\hline 30730 & 3073a & 33.2482078 & -115.5456655 & -62 & 2011 & 63 & 9:09 & 69.0 & 21.0 & 17.7 & 24.4 & 115 & \\
\hline 30770 & $3077 \mathrm{~b}$ & 33.2775192 & -115.5192703 & -17 & 2011 & 63 & 8:09 & 70.5 & 21.5 & 18.6 & 24.4 & 115 & \\
\hline 30790 & 3079b1 \& b2 & 33.2949326 & -115.5111832 & 22 & 2011 & 65 & $10: 18$ & 67.9 & 20.7 & 18.0 & 23.4 & 458 & \\
\hline 30800 & $3079 c$ & 33.2982112 & -115.4986821 & 27 & 2011 & 65 & 9:18 & 72.0 & 21.9 & 18.9 & 25.0 & 230 & \\
\hline 30880 & $3088 b$ & 33.376954 & -115.4740021 & 242 & 2011 & 65 & $8: 18$ & 72.0 & 21.9 & 14.0 & 29.9 & 462 & \\
\hline 30940 & $3094 a$ & 33.4266387 & -115.464656 & 445 & 2011 & 65 & $7: 18$ & 103.5 & 31.5 & 19.2 & 43.9 & 920 & \\
\hline 40000 & $4000 a$ & 33.5018741 & -116.1957772 & 137 & 2011 & 66 & 7:03 & 102.8 & 31.3 & 18.9 & 43.7 & 911 & \\
\hline 40030 & 4003a & 33.5130842 & -116.1647582 & 30 & 2011 & 68 & $7: 42$ & 61.0 & 18.6 & 16.8 & 20.4 & 69 & \\
\hline 40080 & $4008 \mathrm{a}$ & 33.5293285 & -116.1189363 & -63 & 2011 & 68 & $8: 42$ & 69.5 & 21.2 & 18.3 & 24.1 & 115 & \\
\hline 40100 & 4010b & 33.5411753 & -116.1066766 & -70 & 2011 & 68 & $9: 42$ & 66.0 & 20.1 & 16.8 & 23.5 & 115 & \\
\hline 40110 & 4011b & 33.547636 & -116.0820314 & -66 & 2011 & 68 & $7: 18$ & 69.0 & 21.0 & 18.0 & 24.1 & 116 & \\
\hline 40140 & 4014a & 33.5534186 & -116.0559145 & -66 & 2011 & 68 & 10:09 & 83.5 & 25.5 & 19.8 & 31.1 & 456 & \\
\hline 40200 & 4020a & 33.5728778 & -116.0085239 & -8 & 2011 & 68 & 9:09 & 64.5 & 19.7 & 16.8 & 22.6 & 115 & \\
\hline 40210 & $4021 \mathrm{a}$ & 33.5785649 & -115.9957005 & 20 & 2011 & 68 & 8:09 & 63.5 & 19.4 & 17.4 & 21.3 & 64 & \\
\hline 40220 & $4022 b$ & 33.5794478 & -115.9895648 & 42 & 2011 & 68 & 7:09 & 78.5 & 23.9 & 17.4 & 30.5 & 456 & \\
\hline 40240 & $4024 a$ & 33.5882116 & -115.9771426 & 79 & 2011 & 68 & $7: 06$ & 69.5 & 21.2 & 18.9 & 23.5 & 115 & \\
\hline 40260 & $4026 a$ & 33.5880088 & -115.9545077 & 151 & 2011 & 68 & 8:06 & 65.0 & 19.8 & 16.8 & 22.9 & 115 & \\
\hline 40280 & 4028a & 33.6039631 & -115.9236688 & 245 & 2011 & 68 & 9:06 & 65.5 & 20.0 & 16.8 & 23.2 & 116 & \\
\hline 40285 & $4028 b$ & 33.6182171 & -115.9189646 & 258 & 2011 & 68 & 10:03 & 69.0 & 21.0 & 17.7 & 24.4 & 105 & \\
\hline 40300 & 4030a & 33.621296 & -115.9096662 & 285 & 2011 & 68 & 9:03 & 68.3 & 20.8 & 16.8 & 24.8 & 116 & \\
\hline 40320 & 4032b & 33.6258413 & -115.9034462 & 300 & 2011 & 68 & 8:03 & 75.8 & 23.1 & 20.7 & 25.5 & 115 & \\
\hline
\end{tabular}




\begin{tabular}{|c|c|c|c|c|c|c|c|c|c|c|c|c|c|}
\hline $\begin{array}{l}\text { Shot } \\
\text { point ID } \\
\text { (final) }\end{array}$ & $\begin{array}{c}\text { Shot point } \\
\text { ID } \\
\text { (original) }\end{array}$ & $\begin{array}{l}\text { Latitude } \\
\text { (WGS 84) }\end{array}$ & $\begin{array}{l}\text { Longitude } \\
\text { (WGS 84) }\end{array}$ & $\begin{array}{l}\text { Elevation } \\
\text { (m) }\end{array}$ & Year & $\begin{array}{l}\text { Shot } \\
\text { date } \\
\text { (Julian } \\
\text { day) }\end{array}$ & $\begin{array}{l}\text { Shot } \\
\text { time } \\
\text { (UTC) }\end{array}$ & $\begin{array}{l}\text { Depth to } \\
\text { center of } \\
\text { charge } \\
\text { (ft) }\end{array}$ & $\begin{array}{l}\text { Depth to } \\
\text { center of } \\
\text { charge } \\
\text { (m) }\end{array}$ & $\begin{array}{l}\text { Depth to } \\
\text { top of } \\
\text { charge } \\
\text { (m) }\end{array}$ & $\begin{array}{l}\text { Total } \\
\text { hole } \\
\text { depth } \\
\text { (m) }\end{array}$ & $\begin{array}{c}\text { Explosives } \\
\text { loaded } \\
(\mathrm{kg})\end{array}$ & $\begin{array}{c}\text { Colocated } \\
\text { field shot } \\
\text { point } \\
\text { name }\end{array}$ \\
\hline 40360 & $4036 a$ & 33.6418584 & -115.8558156 & 405 & 2011 & 68 & 7:03 & 72.0 & 21.9 & 18.9 & 25.0 & 115 & \\
\hline 40400 & $4040 a$ & 33.6542187 & -115.800137 & 464 & 2011 & 66 & 7:06 & 101.0 & 30.8 & 19.8 & 41.8 & 911 & \\
\hline 50000 & $5000 \mathrm{~b}$ & 33.583934 & -116.4372184 & 1185 & 2011 & 66 & 7:09 & 104.5 & 31.9 & 19.5 & 44.2 & 671 & \\
\hline 50100 & 5010a & 33.6555945 & -116.3960464 & 463 & 2011 & 69 & $10: 45$ & 82.5 & 25.1 & 18.9 & 31.4 & 463 & \\
\hline 50160 & 5016a & 33.70353 & -116.36858 & 98 & 2011 & 69 & $9: 12$ & 75.5 & 23.0 & 20.1 & 25.9 & 92 & \\
\hline 50220 & 5022a & 33.7612312 & -116.3605893 & 72 & 2011 & 69 & $8: 12$ & 75.0 & 22.9 & 19.5 & 26.2 & 115 & \\
\hline 50300 & 5030a & 33.8222093 & -116.3236705 & 113 & 2011 & 69 & 9:18 & 64.0 & 19.5 & 18.0 & 21.0 & 65 & \\
\hline 50310 & 5031c & 33.8308721 & -116.3121376 & 149 & 2011 & 69 & 9:15 & 58.5 & 17.8 & 15.8 & 19.8 & 65 & \\
\hline 50340 & $5034 a$ & 33.8601094 & -116.307841 & 252 & 2011 & 69 & $8: 15$ & 70.8 & 21.6 & 18.6 & 24.5 & 115 & \\
\hline 50380 & $5038 \mathrm{~h}$ & 33.8796432 & -116.2934947 & 362 & 2011 & 69 & $7: 15$ & 100.5 & 30.6 & 18.6 & 42.7 & 911 & \\
\hline 60000 & $6000 \mathrm{~b}$ & 33.8418519 & -116.607443 & 681 & 2011 & 69 & 7:03 & 105.0 & 32.0 & 31.4 & 32.6 & 1025 & \\
\hline 60010 & 6000b_R & 33.8418519 & -116.607443 & 681 & 2011 & 70 & 8:03 & 35.0 & 5.3 & 10.0 & 10.4 & 39 & \\
\hline 60070 & $6007 \mathrm{~b}$ & 33.9285428 & -116.5626466 & 290 & 2011 & 69 & $8: 33$ & 87.5 & 26.7 & 24.4 & 29.0 & 342 & \\
\hline 60120 & $6012 b$ & 33.967022 & -116.5439647 & 357 & 2011 & 69 & 9:33 & 77.5 & 23.6 & 17.1 & 30.2 & 456 & $1230 \mathrm{~b}$ \\
\hline 60160 & 6016a & 34.0123008 & -116.5195927 & 505 & 2011 & 69 & 9:39 & 66.3 & 20.2 & 17.4 & 23.0 & 115 & \\
\hline 60200 & 6020a & 34.0457565 & -116.5049997 & 680 & 2011 & 69 & $8: 39$ & 68.5 & 20.9 & 17.7 & 24.1 & 115 & \\
\hline 60250 & $6025 a$ & 34.0687717 & -116.4810852 & 843 & 2011 & 69 & 7:09 & 99.0 & 30.2 & 21.0 & 39.3 & 455 & \\
\hline 60280 & $6028 \mathrm{~b} 2$ & 34.1006468 & -116.4729721 & 1065 & 2011 & 69 & 10:06 & 64.5 & 19.7 & 17.1 & 22.3 & 115 & \\
\hline 60350 & $6035 a$ & 34.1482459 & -116.4574762 & 1249 & 2011 & 69 & $8: 36$ & 94.3 & 28.7 & 27.7 & 29.7 & 103 & \\
\hline 60380 & $6038 x$ & 34.1866435 & -116.4338515 & 1110 & 2011 & 69 & $7: 36$ & 103.4 & 31.5 & 20.4 & 42.6 & 926 & \\
\hline 70000 & 7000a1 \& a2 & 33.4929506 & -115.7702492 & 8 & 2011 & 73 & $6: 38$ & 40.4 & 12.3 & 11.0 & 13.6 & 93 & \\
\hline 70010 & 7001a & 33.487771 & -115.7796354 & -7 & 2011 & 73 & $7: 38$ & 72.0 & 21.9 & 19.5 & 24.4 & 116 & \\
\hline 70020 & 7002a1 \& a2 & 33.4832084 & -115.7887228 & -48 & 2011 & 73 & $9: 38$ & 37.5 & 11.4 & 10.7 & 12.2 & 70 & \\
\hline 70030 & 7003a1 \& a2 & 33.4785948 & -115.7977257 & -35 & 2011 & 73 & $6: 06$ & 37.3 & 11.4 & 10.5 & 12.2 & 70 & \\
\hline
\end{tabular}




\begin{tabular}{|c|c|c|c|c|c|c|c|c|c|c|c|c|c|}
\hline $\begin{array}{c}\text { Shot } \\
\text { point ID } \\
\text { (final) }\end{array}$ & $\begin{array}{c}\text { Shot point } \\
\text { ID } \\
\text { (original) }\end{array}$ & $\begin{array}{l}\text { Latitude } \\
\text { (WGS 84) }\end{array}$ & $\begin{array}{l}\text { Longitude } \\
\text { (WGS 84) }\end{array}$ & $\begin{array}{l}\text { Elevation } \\
\text { (m) }\end{array}$ & Year & $\begin{array}{c}\text { Shot } \\
\text { date } \\
\text { (Julian } \\
\text { day) }\end{array}$ & $\begin{array}{l}\text { Shot } \\
\text { time } \\
\text { (UTC) }\end{array}$ & $\begin{array}{l}\text { Depth to } \\
\text { center of } \\
\text { charge } \\
\text { (ft) }\end{array}$ & $\begin{array}{l}\text { Depth to } \\
\text { center of } \\
\text { charge } \\
\text { (m) }\end{array}$ & $\begin{array}{l}\text { Depth to } \\
\text { top of } \\
\text { charge } \\
\text { (m) }\end{array}$ & $\begin{array}{l}\text { Total } \\
\text { hole } \\
\text { depth } \\
\text { (m) }\end{array}$ & $\begin{array}{l}\text { Explosives } \\
\text { loaded } \\
(\mathrm{kg})\end{array}$ & $\begin{array}{c}\text { Colocated } \\
\text { field shot } \\
\text { point } \\
\text { name }\end{array}$ \\
\hline 70045 & $7004.5 a$ & 33.4725873 & -115.8122416 & -43 & 2011 & 73 & 8:06 & 7.8 & 2.4 & 2.3 & 2.4 & 3 & \\
\hline 70040 & 7004b1 \& b2 & 33.47536225 & -115.8079102 & -45 & 2011 & 73 & 7:06 & 19.5 & 5.9 & 5.6 & 6.2 & 24 & \\
\hline 70055 & 7005.5a & 33.4663265 & -115.821207 & -33 & 2011 & 73 & $7: 34$ & 7.8 & 2.4 & 2.3 & 2.4 & 4 & \\
\hline 70050 & $7005 a$ & 33.4686571 & -115.8166547 & -41 & 2011 & 73 & 8:04 & 14.0 & 4.3 & 4.0 & 4.6 & 9 & \\
\hline 70065 & 7006.5a & 33.4623431 & -115.8308754 & -53 & 2011 & 73 & $6: 02$ & 14.0 & 4.3 & 4.0 & 4.6 & 9 & \\
\hline 70060 & $7006 a$ & 33.4644384 & -115.8260889 & -37 & 2011 & 73 & $6: 04$ & 14.0 & 4.3 & 4.0 & 4.6 & 9 & \\
\hline 70075 & 7007.5a & 33.458766 & -115.8394116 & -31 & 2011 & 73 & 8:02 & 11.7 & 3.6 & 3.3 & 3.8 & 9 & \\
\hline 70070 & $7007 a$ & 33.4604661 & -115.8344902 & -48 & 2011 & 73 & $7: 02$ & 14.0 & 4.3 & 4.0 & 4.6 & 9 & \\
\hline 70085 & 7008.5a & 33.4530329 & -115.8495099 & -54 & 2011 & 73 & 8:00 & 7.8 & 2.4 & 2.3 & 2.4 & 4 & \\
\hline 70080 & $7008 \mathrm{a}$ & 33.4562487 & -115.8439257 & -31 & 2011 & 73 & 9:00 & 9.8 & 3.0 & 2.8 & 3.1 & 5 & \\
\hline 70090 & $7009 a$ & 33.4505444 & -115.8541563 & -73 & 2011 & 73 & $7: 00$ & 7.8 & 2.4 & 2.3 & 2.4 & 4 & \\
\hline 81360 & 8136b & 33.2379081 & -115.9720482 & -20 & 2011 & 75 & $7: 30$ & 63.5 & 19.4 & 14.3 & 24.4 & 365 & \\
\hline
\end{tabular}


Table 5. Land shot-hole shooting details for six shot points. Data for all shot holes are available in appendix VIII.

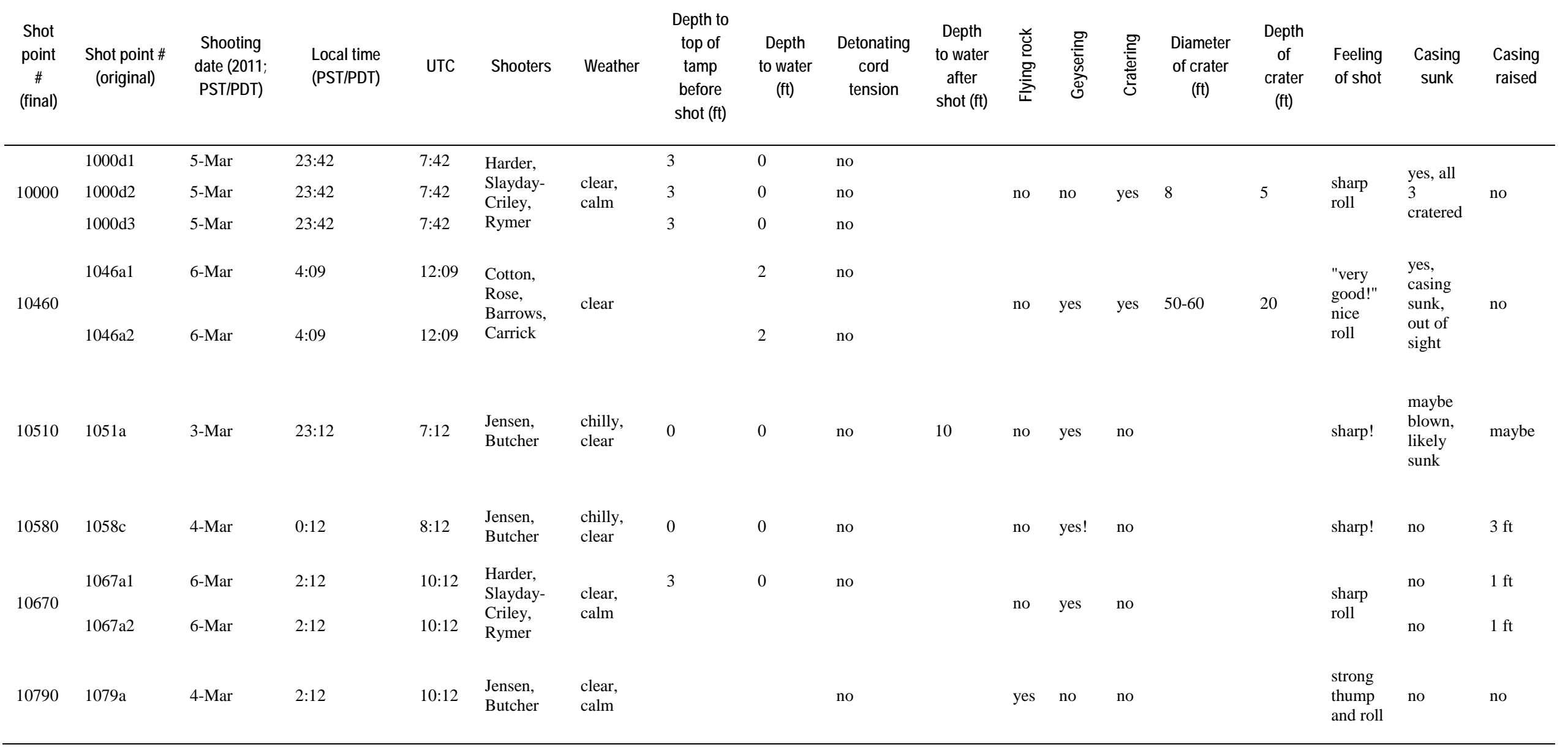


shot time, the supervisory shooter trimmed the detonating cord emerging from the shot hole and attached a detonator ("cap") to the cord. The cord and cap were buried gently in the shot hole to eliminate air waves from the shot initiation. The shot was initiated electronically on the precise minute mark, with an error in timing estimated to be less than 10 microseconds. After every shot, the site was secured and the shooting team moved on to their next shot as efficiently as possible.

A total of 126 shots were detonated over a period of 2 weeks, from Julian days 62-75 (March 3-16). Two shots (10870 and 30640; table 4) that failed to detonate within their shot windows were set off at a later time, after our portable seismometers were picked up. We used our shooting systems for these late detonations so that records on the permanent seismic network would be useful for studying crustal-structure. Maps showing the day-by-day schedule of seismometer deployment and shooting comprise figure 14 . This schedule was set up months in advance so that the marine activities, including OBS deployments and air gun shots, could be coordinated with land activities.

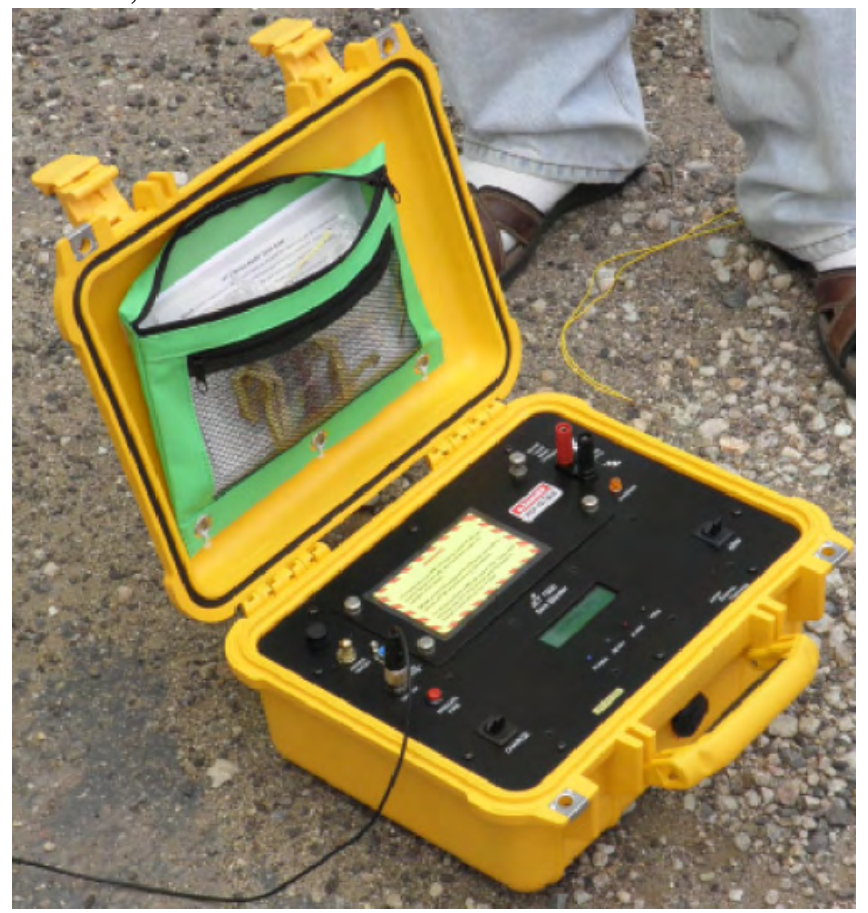

Figure 13. Photograph of the shooting system built for SSIP by retired electronic engineer and explosives handler, Edward Jensen. GPS antenna (out of the photograph to the left) is attached to the system by small black cable shown. Shot wire (yellow wire in upper right) is attached to the red and black terminals on the right side of the box. The shooting system releases a stored charge into the shot wire on the exact minute mark following arming of the system. 

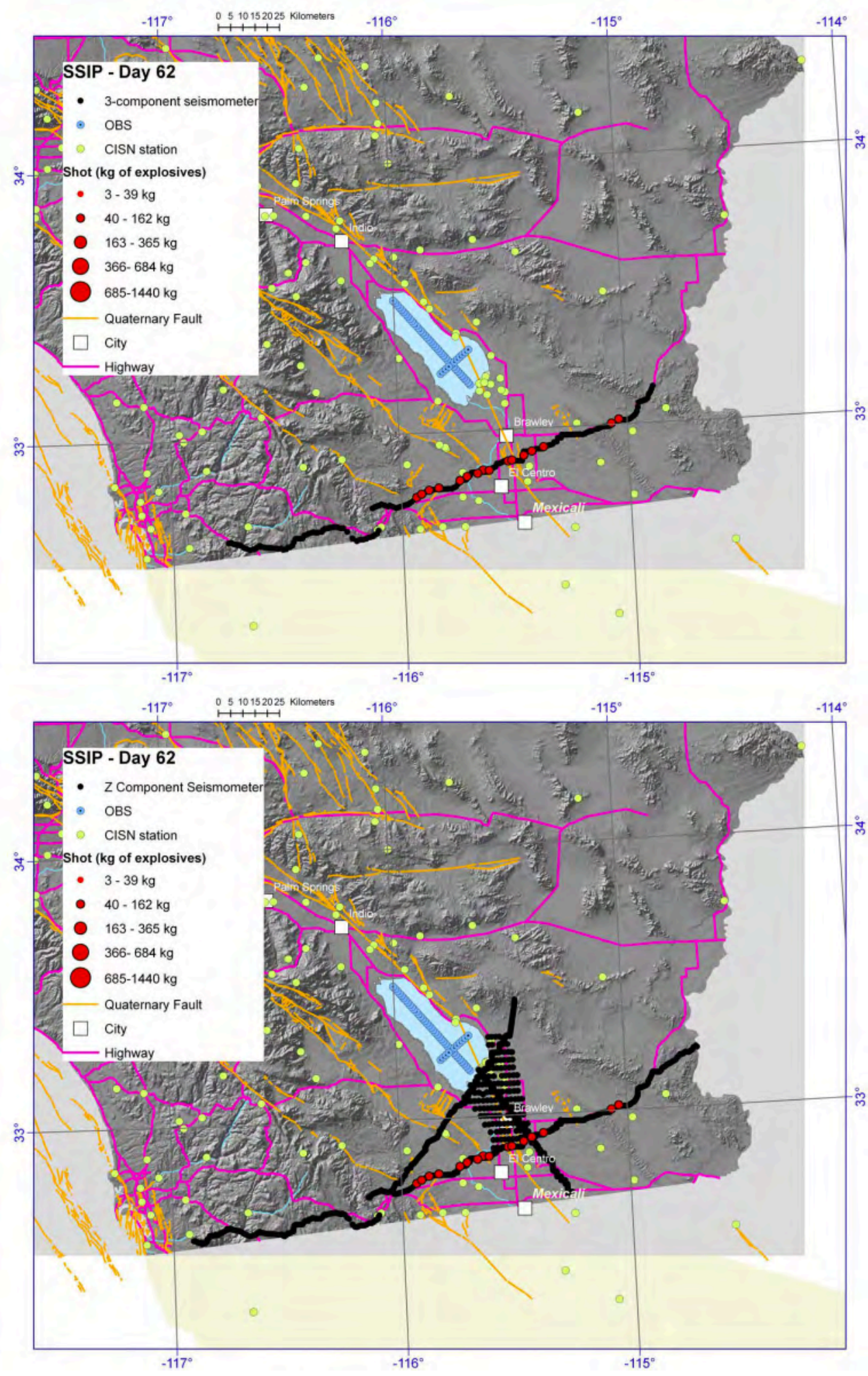

Figure 14a. Maps of seismometers, ocean-bottom seismometers, and land shots by Julian day, from days $62-76$. Seventeen panels shown. 

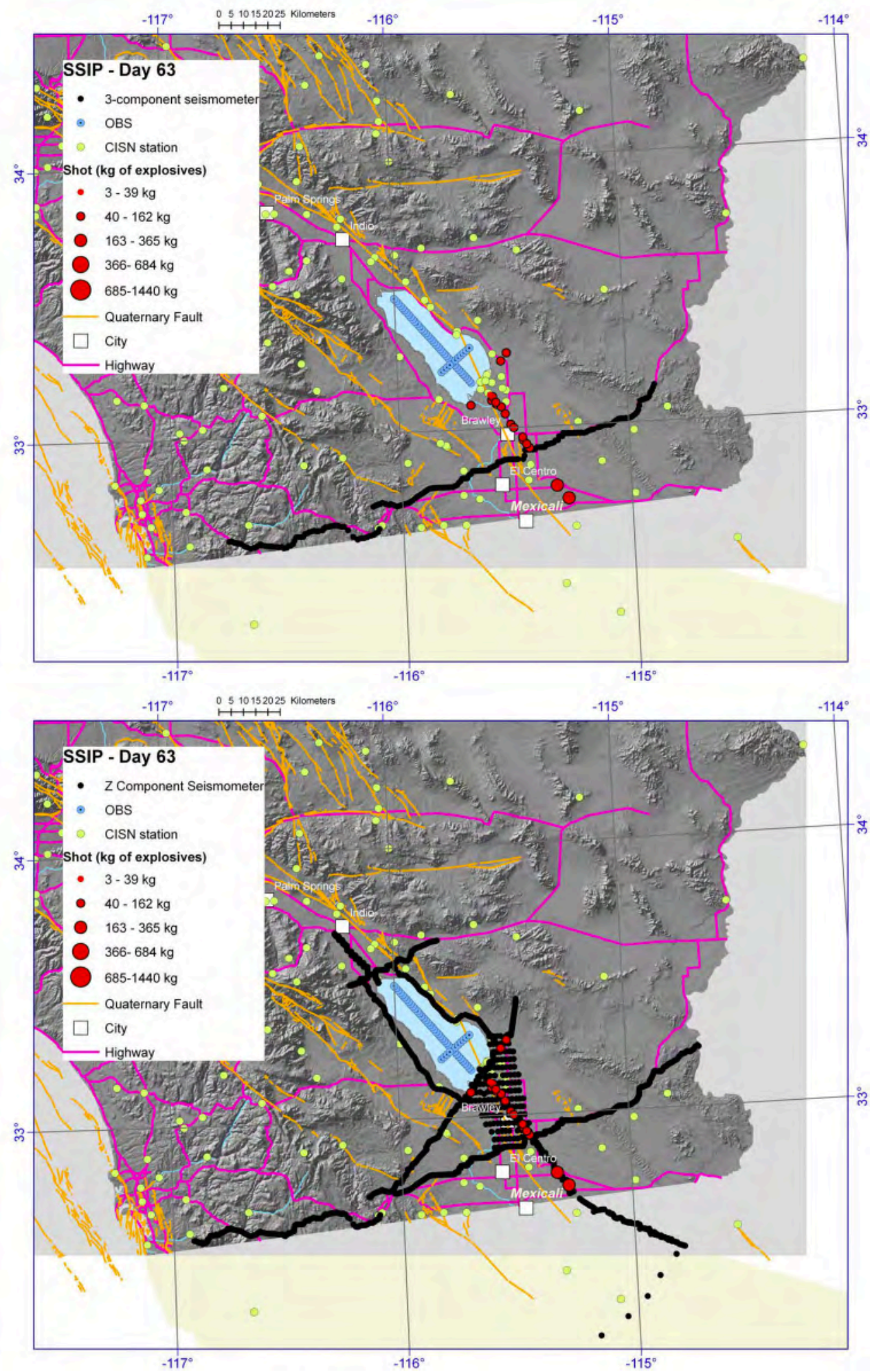

Figure 14a.-Continued. 

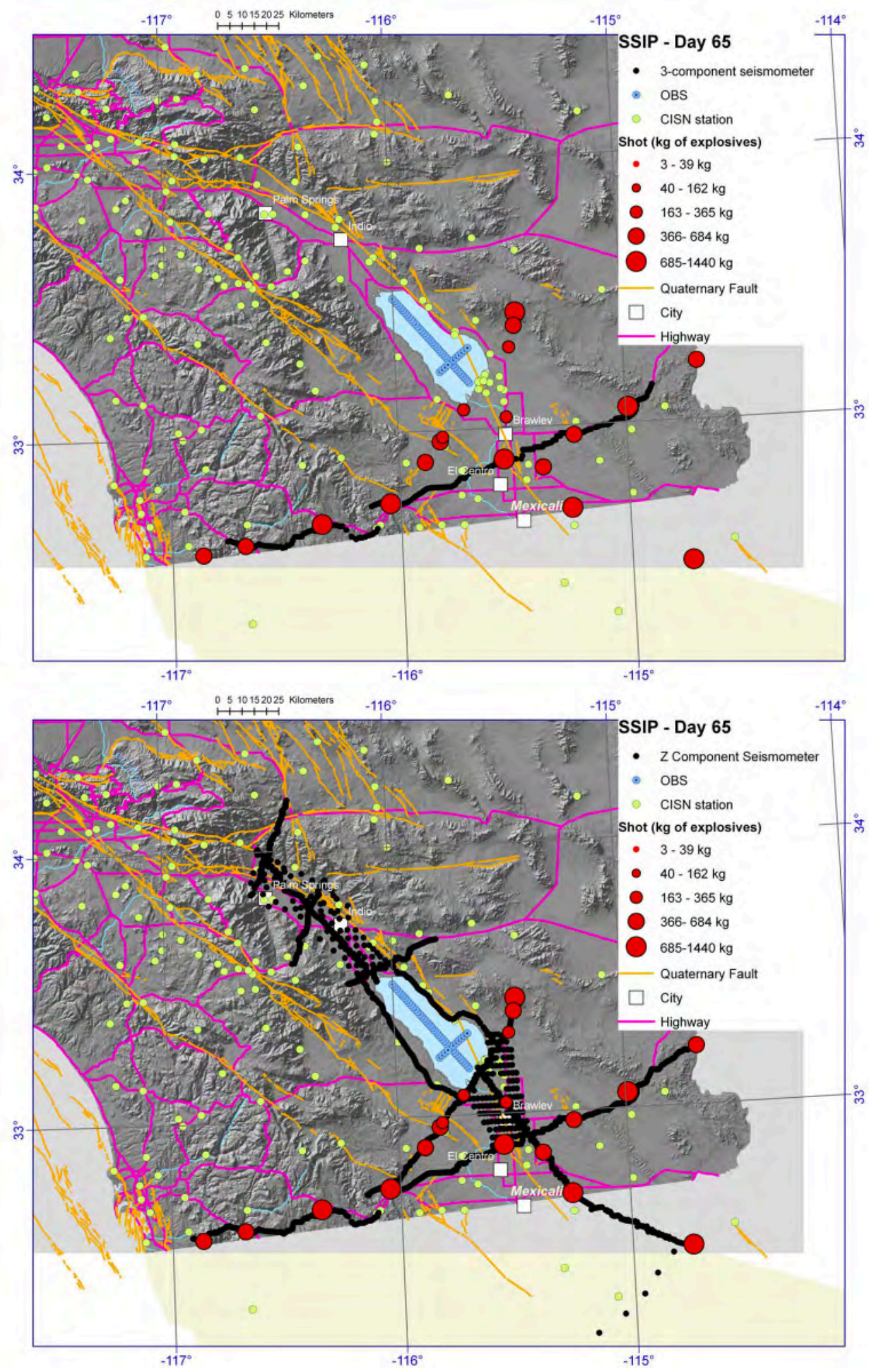

Figure 14a.-Continued. 

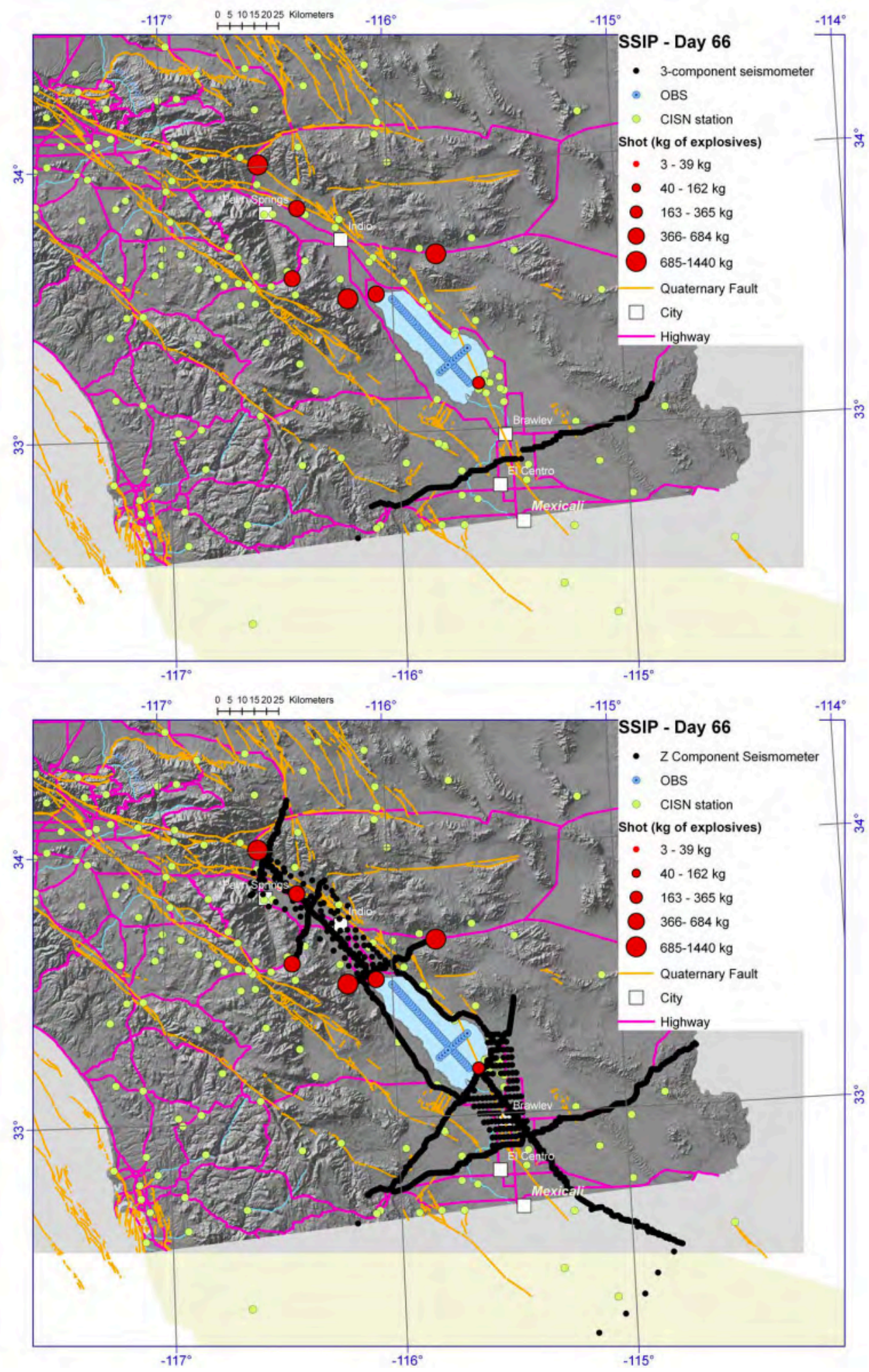

Figure 14a.-Continued. 

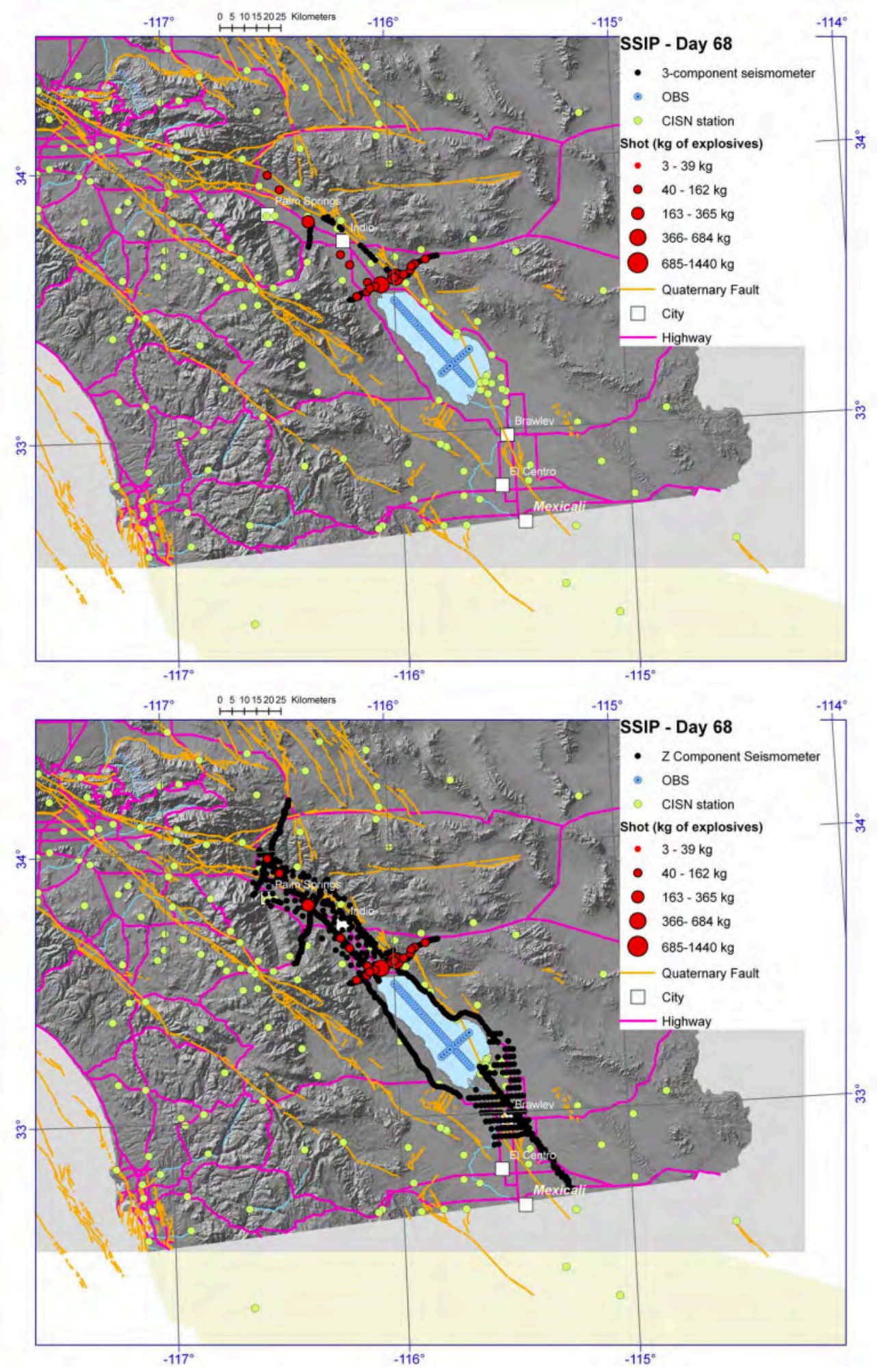

Figure 14a.-Continued. 

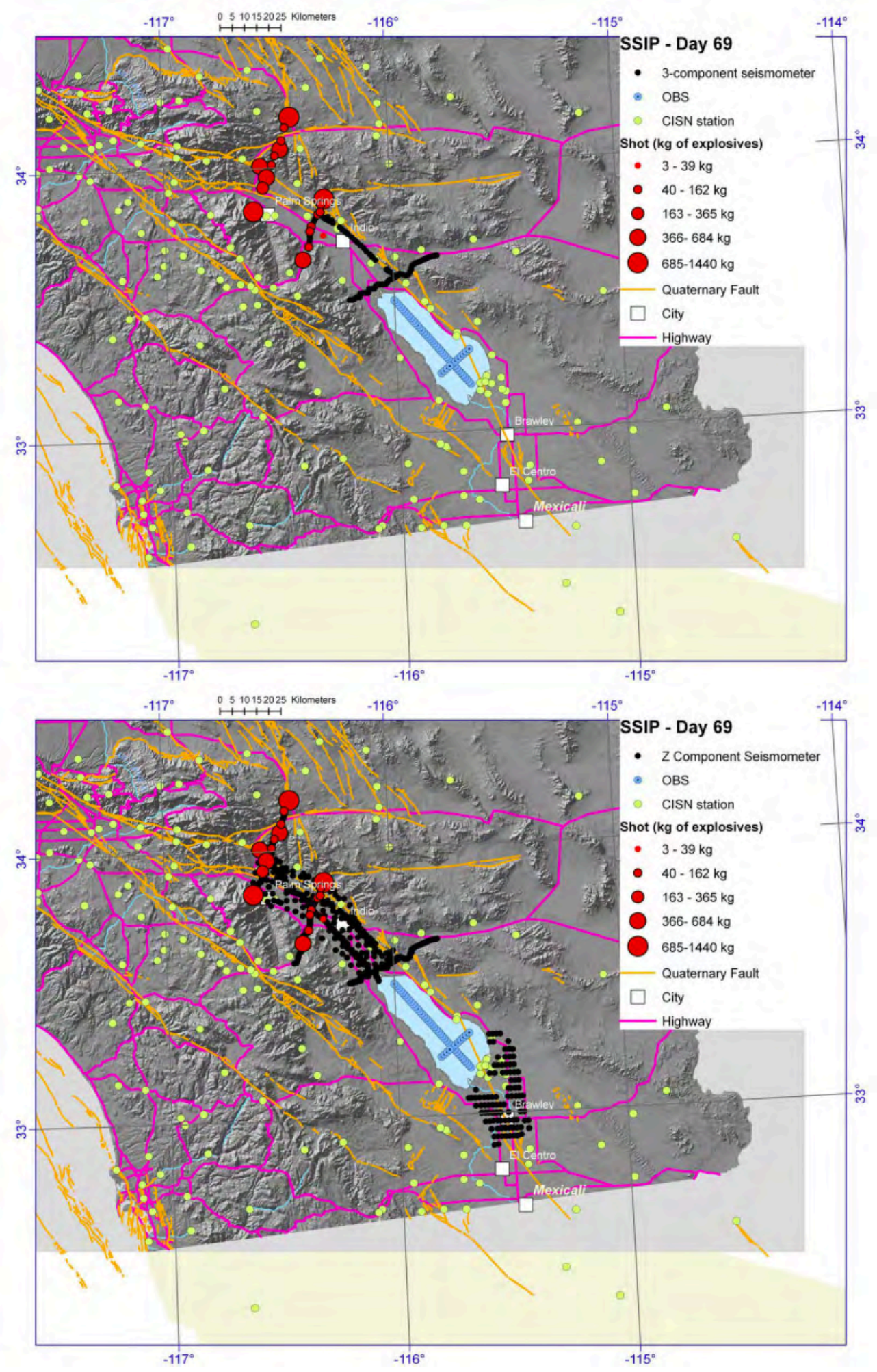

Figure 14a.-Continued. 

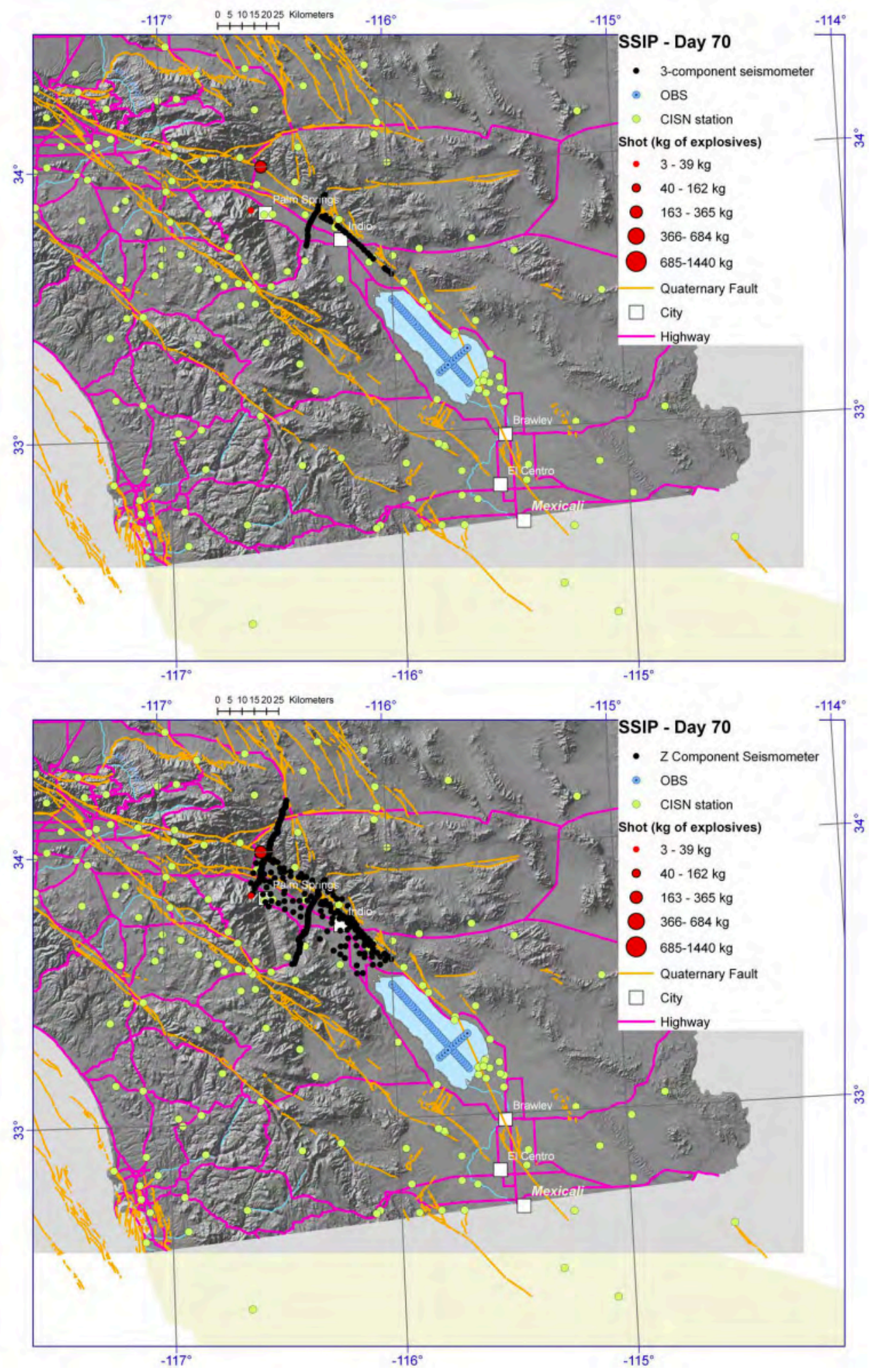

Figure 14a.-Continued. 

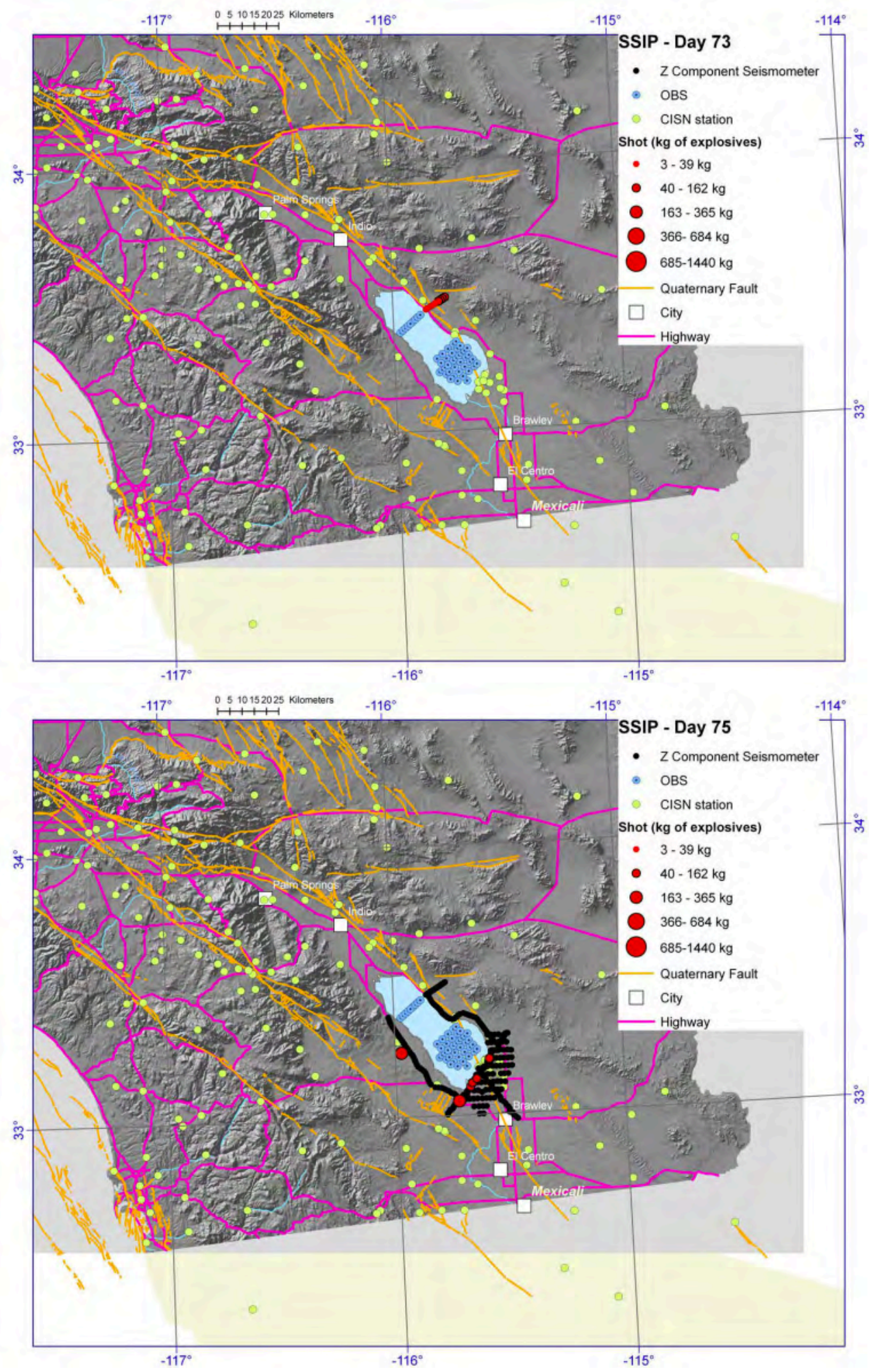

Figure 14a.-Continued. 


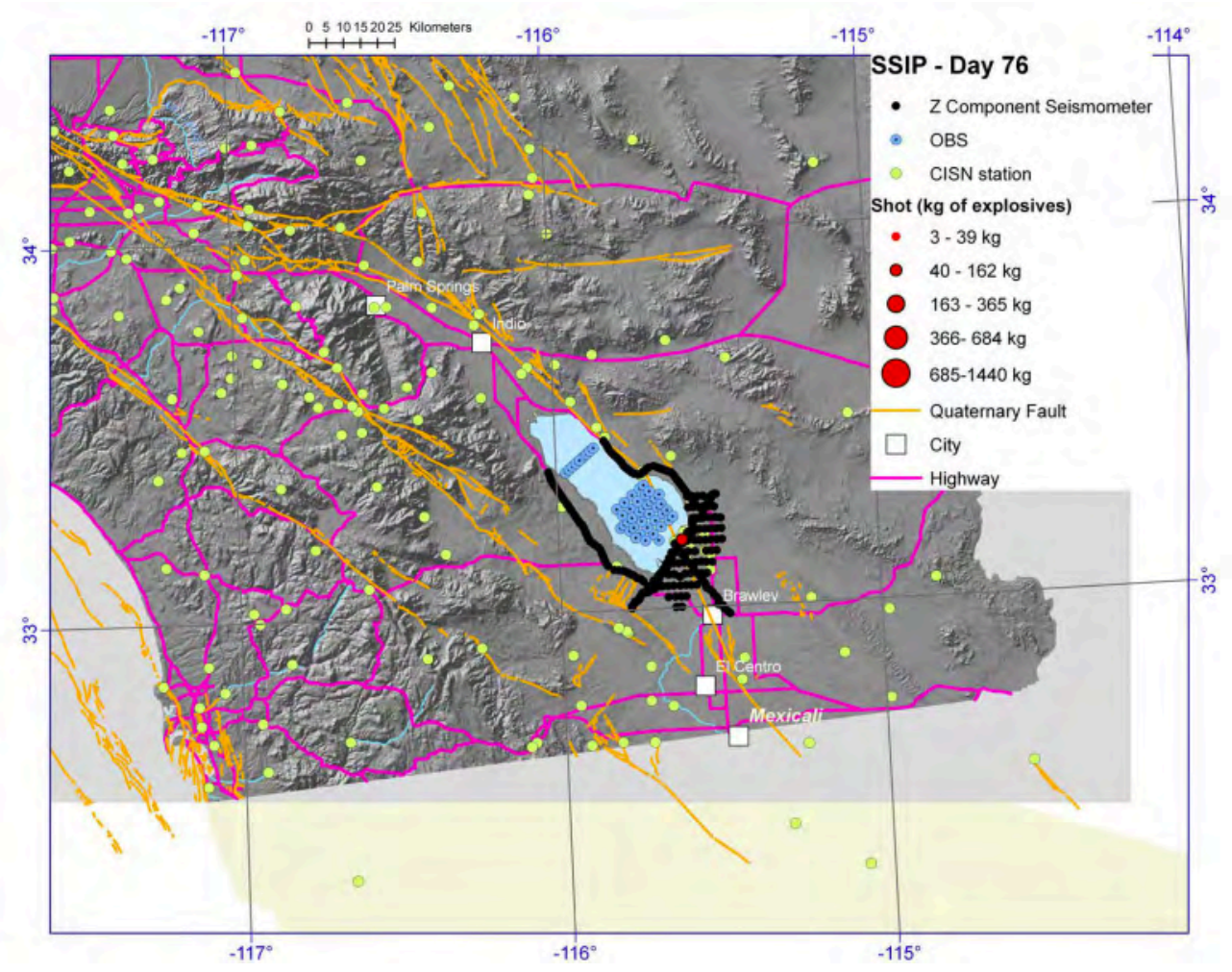

Figure 14a.-Continued. 

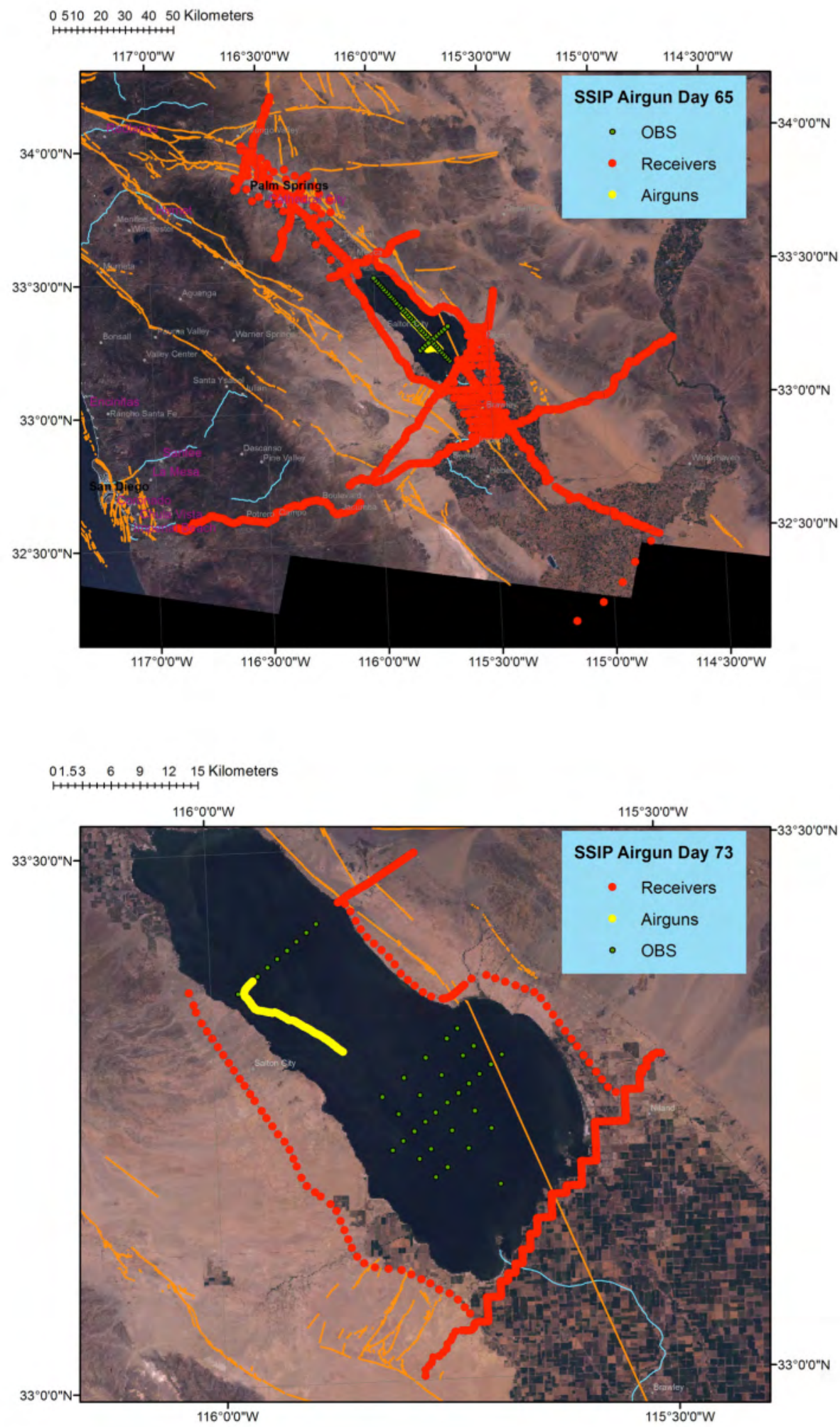

Figure $14 b$. Six maps of seismometers, ocean-bottom seismometers, and air-gun shots by Julian day. 

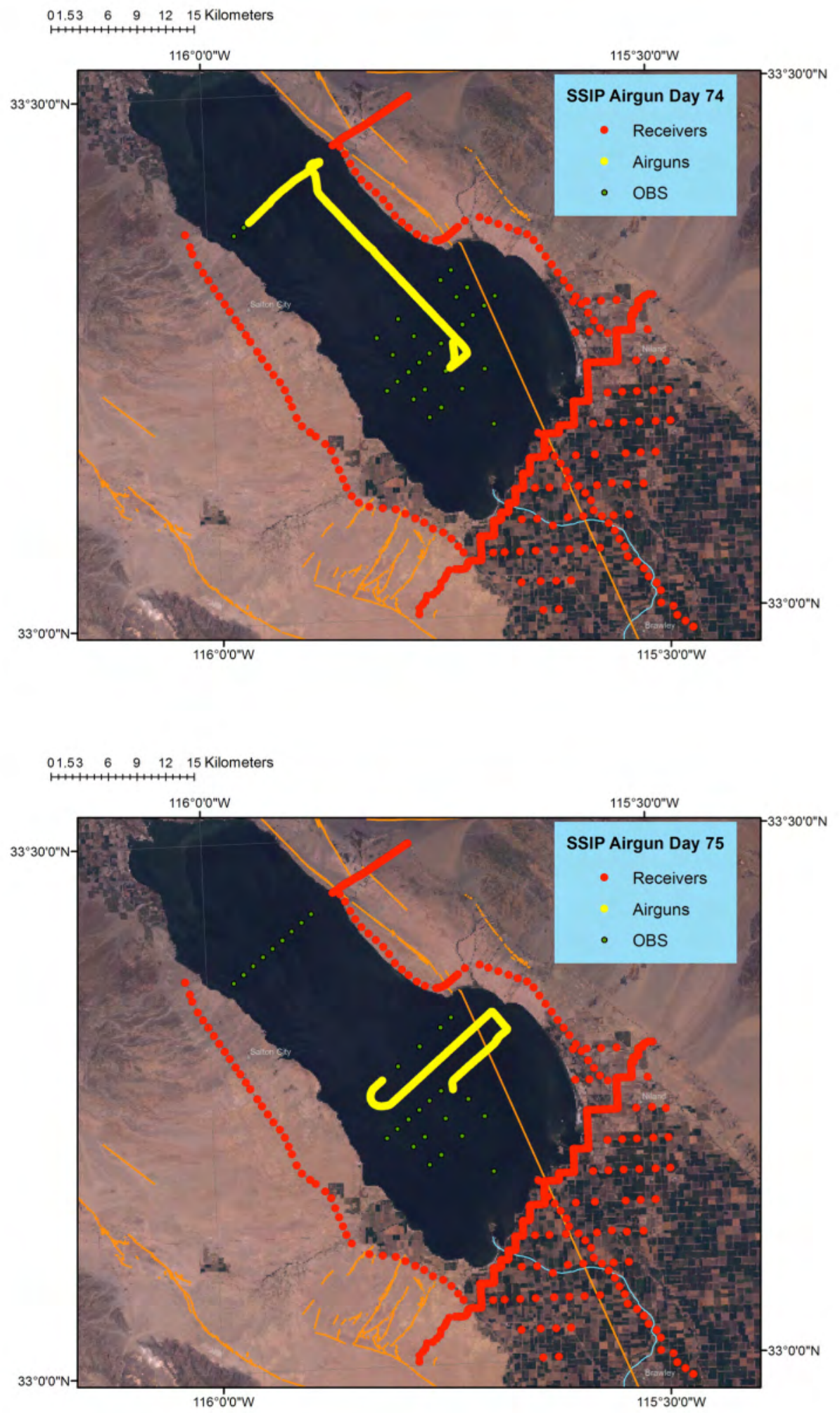

Figure $14 b .-C o n t i n u e d$. 

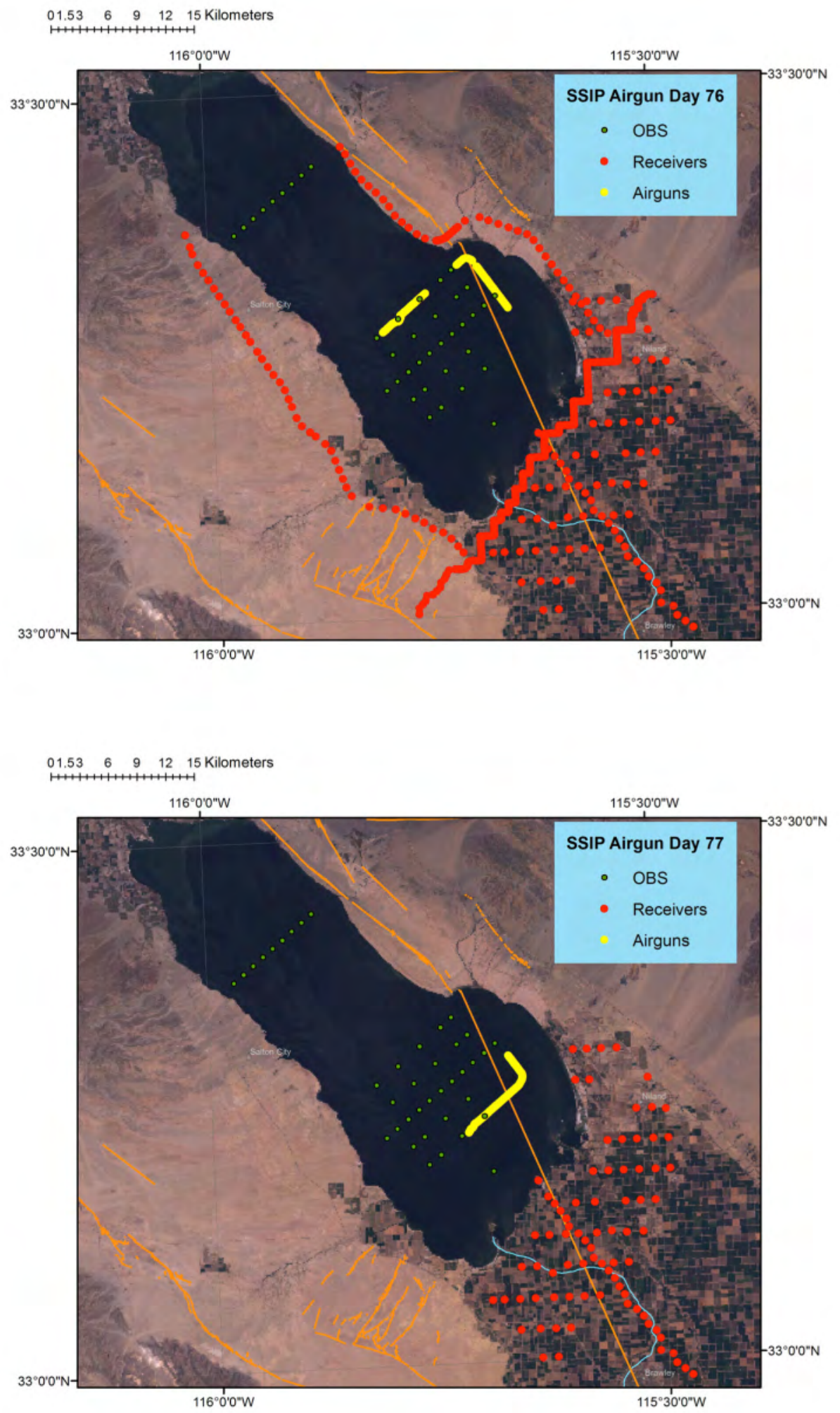

Figure $14 b .-C o n t i n u e d$. 


\section{Land Seismometer Deployment}

\section{Line Scouting, Surveying, Staking, Logging}

(See appendix III for land seismometer locations, and appendix VII (online only) for KMZ files).

Initial scouting for shot locations in the United States was done by the PIs from the USGS, Virginia Tech, Caltech, and CICESE starting in May 2008. After shot locations were determined, planning began for the seismometer locations, generally along lines connecting shot points. Provisional seismometer locations in the United States were determined by Virginia Tech, in consultation with the other collaborators. Taken into account were: the desired receiver spacing (which varied within the project according to the scientific objectives for each line), the total number of seismometers that would be available, and anticipated field logistics, including power supply related limitations of the data loggers, and whether the seismometer sites were accessible by vehicle or by foot.

During January 2011, four field teams consisting of two or three people each (from the USGS, Caltech, Virginia Tech, and including a student volunteer from MIT) did the final scouting, surveying, and staking of most of the seismometer locations. Field teams were instructed regarding desired spacing of seismometers, desired ground conditions for optimal signal-to-noise ratio, and instrument security-related concerns. Locations adjacent to public roads were used wherever possible. A wooden stake was driven in at each planned seismometer location with a line number and field station number written on it. The coordinates of each stake were recorded with a handheld GPS receiver (Trimble GeoXH ${ }^{\mathrm{TM}}$ ). Stake locations were post-processed using Trimble's GPS Pathfinder ${ }^{\circledR}$ Office at the end of each day of surveying, in order to obtain a location accuracy of $30 \mathrm{~cm}$ vertically and horizontally. This archive of stake locations was used in assigning the locations to instrument deployment and retrieval crews in February and March.

Some seismometer locations could not be pre-surveyed or staked during January 2011. These included locations on: military lands (parts of Line 3 in the Chocolate Mountains and Superstition Mountain area, and part of Line 2 on the US. Naval Air Facility west of El Centro); Coachella Valley wilderness area (part of Line 5); private lands on windmill farms (along part of Line 6); private lands in some gated communities in the Coachella Valley; and the part of line 1S located in Mexico. These locations were surveyed at the time of deployment of the seismometers.

\section{Instrument Staging}

The Texan ${ }^{\mathrm{TM}}$ and RT130 ${ }^{\mathrm{TM}}$ data loggers (equipped with seismometers; table 7) were delivered by the Incorporated Research Institutions for Seismology (IRIS) to a warehouse in El Centro where initial instrument programming took place. Five IRIS employees worked in the warehouse to provide support for programming (fig. 15) and also for downloading the data. In order to conserve battery life, a programming schedule was used whereby the instruments would be "live" and recording at a 1 mil (0.001 second) sample rate, for only 7 hours per day (typically from 0700 to 1400 UTC, or 11 p.m. to 6 a.m. Pacific Standard (local) Time; table 4). An exception was made for instruments that were going to be recording the air gun shots that were planned to occur on the Salton Sea during local daylight hours (Julian days 65-77; table 6). Those 
instruments were programmed to record continuously. Each evening, the required number of instruments was prepared and programmed by IRIS personnel so that the instruments could be picked up from the warehouse in the morning and taken to the field and deployed. Field volunteers assisted with changing the D-cell batteries in the recording units.

SALTON RT130 WAREHOUSE CHECKLIST

BEFORE DOING ANYTHING PULL THE CF CARD FROM THE RT130 AND VERIFY IT AGAINST A LIST OF BAD DISKS.

Power-Up RT130

Connect GPS to DAS and then connect Power.

RT130 Setup

1. Send Parameters to DAS

BE SURE TO SELECT THE SALTON PROGRAM

Work with Config $\Rightarrow$ load $\Rightarrow$ salton

$\Rightarrow$ Send to DAS

$\Rightarrow$ From DAS $\Rightarrow$ Edit $\Rightarrow$ Verify experiment name:

2. Clear RAM (Control $\Rightarrow R A M \Rightarrow$ Clear)

3. Reset System (Control $\Rightarrow$ Reset)

4. Format Flash Disk (Control $\Rightarrow$ Format Disk) Disk 1:

5. Check Clock Status (Control $\Rightarrow$ Status $\Rightarrow$ GPS)

Time since LL:

*Note clock MUST lock before starting acquisition

Phase Diff: $\mu$ s (should be a small number)

6. Disk Setup (Control $\Rightarrow$ Disk)

Dump Threshold:

Auto-wrap Dump on ET

$66 \%$

No (select the pull-down arrow to change setting if necessary) No

Tap the SEND button to send the information to the DAS

7. Write .CFG File to Disk (Control $\Rightarrow$ Status $\Rightarrow$ DAS LPNP)

Tap the WRITE button to write the .cfg file to the disk.

8. DAS status (Control $\Rightarrow$ Status)

Verify that Disk 1 usage is now slightly more than 0

Verify Power: bkp charge is $03.3 \mathrm{bkp}$

Figure 15. RT130 programming sheet used by deployment teams.

Table 6. Air-gun shot times and locations for 5 shots. Data for all shots are given in appendix VIII.

\begin{tabular}{|c|c|c|c|c|c|c|c|c|}
\hline $\begin{array}{l}\text { Line } \\
\text { number }\end{array}$ & Julian day & $\begin{array}{l}\text { Hour } \\
\text { (UTC) }\end{array}$ & Minute & Second & $\begin{array}{l}\text { Latitude } \\
\text { (WGS 84) }\end{array}$ & $\begin{array}{l}\text { Longitude } \\
\text { (WGS 84) }\end{array}$ & $\begin{array}{l}\text { Elevation } \\
\text { (m) }\end{array}$ & $\begin{array}{c}\text { Depth } \\
\text { under } \\
\text { water }(m)\end{array}$ \\
\hline 1 & $2011+064$ & 21 & 24 & 0.1 & 33.490262 & $\begin{array}{l}- \\
115.995877\end{array}$ & -69.8 & -4 \\
\hline 1 & $2011+064$ & 21 & 25 & 0.1 & 33.489596 & $\begin{array}{l}- \\
115.995192\end{array}$ & -69.8 & -4 \\
\hline 1 & $2011+064$ & 21 & 26 & 0.1 & 33.488931 & $\begin{array}{l}- \\
115.994561\end{array}$ & -69.8 & -4 \\
\hline 1 & $2011+064$ & 21 & 27 & 0.1 & 33.488294 & $\begin{array}{l}- \\
115.993913\end{array}$ & -69.8 & -4 \\
\hline 1 & $2011+064$ & 21 & 28 & 0.1 & 33.487658 & $\begin{array}{l}- \\
115.993247\end{array}$ & -69.8 & -4 \\
\hline
\end{tabular}


Table 7. Seismic acquisition systems: parameters.

\begin{tabular}{|c|c|c|c|c|c|c|c|c|c|}
\hline $\begin{array}{l}\text { Instrument } \\
\text { (data } \\
\text { logger) type }\end{array}$ & $\begin{array}{l}\text { Number } \\
\text { used }\end{array}$ & $\begin{array}{c}\text { Seismometer } \\
\text { type }\end{array}$ & $\begin{array}{l}\text { Data } \\
\text { storage } \\
\text { type }\end{array}$ & Memory & $\begin{array}{l}\text { A-D bit } \\
\text { size }\end{array}$ & Timing type & $\begin{array}{c}\text { Sensor } \\
\text { freq. } \\
\text { (Hz) }\end{array}$ & $\begin{array}{c}\text { Sensor } \\
\text { compo- } \\
\text { nents }\end{array}$ & $\begin{array}{c}\text { Sample } \\
\text { rate } \\
\text { (sps) }\end{array}$ \\
\hline $\begin{array}{l}\text { Ref Tek } \\
130 \\
\text { ("RT130's") }\end{array}$ & 185 & $\begin{array}{l}\text { Sercel L-28- } \\
\text { 3D high } \\
\text { frequency } \\
\text { sensor }\end{array}$ & $\begin{array}{l}\text { two 2GB } \\
\text { compact } \\
\text { flash } \\
\text { disks }\end{array}$ & 4GB & 24-bit & $\begin{array}{l}\text { high- } \\
\text { precision } \\
\text { TCXO } \\
\text { disciplined } \\
\text { by an ext. } \\
\text { GPS. } \\
\text { Accuracy } \\
\text { greater than } \\
0.001 \text { ms } \\
\text { w/GPS }\end{array}$ & 4.5 & 3 & 250 \\
\hline $\begin{array}{l}\text { Ref Tek } \\
125 a \\
\text { ("Texans") }\end{array}$ & 2524 & $\begin{array}{l}\text { OYO } \\
\text { Geospace } \\
\text { GS-11D }\end{array}$ & $\begin{array}{l}\text { flash } \\
\text { drive }\end{array}$ & $256 \mathrm{mb}$ & 24-bit & $\begin{array}{l}\text { synced to } \\
\text { ext. GPS } \\
\text { before and } \\
\text { immediately } \\
\text { after } \\
\text { deployment }\end{array}$ & 4.5 & 1 & 250 \\
\hline $\begin{array}{l}\text { L- } \\
\text { CHEAPO } \\
4 \times 4 \\
\text { ("OBS's") }\end{array}$ & 48 & $\begin{array}{l}\text { Sercel L-28- } \\
\text { 3D high } \\
\text { frequency } \\
\text { sensor }\end{array}$ & $\begin{array}{l}3 \\
\text { compact } \\
\text { flash card } \\
\text { slots }\end{array}$ & $64 \mathrm{~Gb}$ & 24-bit & $\begin{array}{l}\text { Seascan } \\
\text { low-power, } \\
\text { DTCXO, } \\
\text { precision } \\
\text { time base. } \\
\text { Drift of <5 } \\
\text { ms/day } \\
\text { before } \\
\text { correction }\end{array}$ & 4.5 & 4 & 200 \\
\hline
\end{tabular}

During the second week of the field deployments, when many of the instrument sites were in the Coachella Valley, the project also used a smaller warehouse in Indio as a secondary base of operations. All instruments were returned to El Centro for the third week of field operations. The final downloading of data and shipment of the instruments back to IRIS took place in El Centro.

Texan instruments sent to Mexico were shipped separately from IRIS to CICESE via San Diego. 


\section{Field Personnel and Training for Instrument Deployment and Pickup}

Approximately 80 people-including PIs, students, USGS employees, and other volunteers-participated in the land-based seismometer deployments and retrievals in the United States during the course of the project. The majority of these participants attended a 2-day training session that was given by the PIs and by IRIS personnel at Imperial Valley College in Imperial, Calif., on February 25 and 26, 2011. During this training session, field participants were taught how to deploy both types of instruments (Texans and RT130s), and given an orientation regarding the logistics of how to find the stakes where they would deploy the seismometers, and how to fill out the necessary instrument forms. Not all participants could attend this training; for those who joined the project after the first week of deployments, a shorter training session was provided at the warehouse on March 6, 2011.

Deployment teams were assigned each evening and given a list of stake positions that they would need to visit. Team assignments were rotated among vehicles and among participants according to the driving conditions (such as whether four-wheel drive would be needed), amount of cargo space required (because RT130 data loggers took up a lot more space than Texan data loggers), and whether teams needed to hike cross-country (in which case, extra people or vehicles might be assigned to the field team for efficacy). The number of seismometer locations assigned to a given field team also depended on the difficulty of accessing those particular stake locations and whether they were performing drop-offs (which were more time consuming) or pickups (which generally went faster).

\section{Instrument Deployment}

Texan data loggers were prepared by IRIS personnel in the warehouse. The instruments were programmed and placed into hard-sided plastic cases with foam inserts, which could hold up to 15 instruments each. Each deployment crew arrived at the warehouse early in the morning and took the box(es) of Texan data loggers and number of geophones assigned to them, as well as maps and a Garmin Etrex ${ }^{\mathrm{TM}}$ handheld GPS receiver containing the locations of the stakes they were to visit. Deployment procedure for the Texan data loggers included:

1. Shoveling an 8-in. deep hole in the dirt near the stake.

2. Recording the location, stake number and the Texan data logger 4-character serial number on the deployment spreadsheet (fig. 16).

3. Placing the geophone in the hole vertically (using a bubble level) and connecting the geophone to the recording unit (data logger).

4. Wrapping the recording unit and part of the cable in a plastic bag that was then sealed with electrical tape (to keep out dirt and/or mud).

5. Pushing a button on the recording unit to activate it.

6. Placing the data logger in the hole, and covering the hole up with dirt so that none of the instrumentation was visible.

Deployment procedure for the Refteks (RT130 data loggers) included:

1. Connecting the RT130 to the GPS receiver and powering it up so that it could start to get a GPS lock while the sensor hole was being dug. 
2. Digging a hole, installing the sensor, leveling it and measuring its orientation (one arrow aligned to magnetic North using a Brunton compass).

3. Connecting the sensor to the Data Acquisition System (DAS).

4. Following detailed instructions on RT130 Install Sheet (fig. 17) and filling out entries for stomp test, clock status, etc.

After each team had finished its deployment, a member would report in by mobile phone to the designated contact person. The team would return to the warehouse and enter the stake numbers and serial numbers of instruments that had been deployed into a computer spreadsheet, as well as noting any difficulties that were encountered.

Deployment of instruments started on February 28 and continued for 3 days before the first set of shots was detonated. Deployments and retrievals continued through March 16 (fig. 14). Instrument retrievals continued on March 17-19 (Julian days 76-78) after land shooting ended in the early hours of March 17 . As many as 22 field teams were active each day during the course of the experiment.

\section{Instrument Pickup}

Upon retrieval of a Texan data logger, the station number, instrument ID number ("Texan \#”), and time of instrument retrieval were recorded on the instrument pickup spreadsheet (fig. 16). Texan recording units and geophones were cleaned off with a towel and placed back into their respective plastic cases or holders. All instrumentation was returned to the warehouse. Field parties entered details, such as which stakes had been visited and the serial numbers of the instruments that had been retrieved into spreadsheets on the computers in the warehouse.

For the RT130s, retrievals at each field site followed all procedures indicated on the RT130 Station Removal Sheet (fig. 18). The instruments were then returned to the warehouse, and the field parties filled in the information on the computer spreadsheets, as above.

\section{Instrument Downloading}

After instruments were returned to the warehouse, IRIS personnel downloaded the data by connecting the instruments in parallel (as many as 45 Texans at a time) to a download computer. Once the data were downloaded, the instrument could then be reprogrammed for redeployment the next day.

Because we had continuous recording of 7 hours at a time, all data files were stored in PH5 format (which has no time limit). PH5 format is IRIS PASSCAL's implementation of the hierarchical data format, version 5 (HDF5) (Folk and Pournal, 2010). 


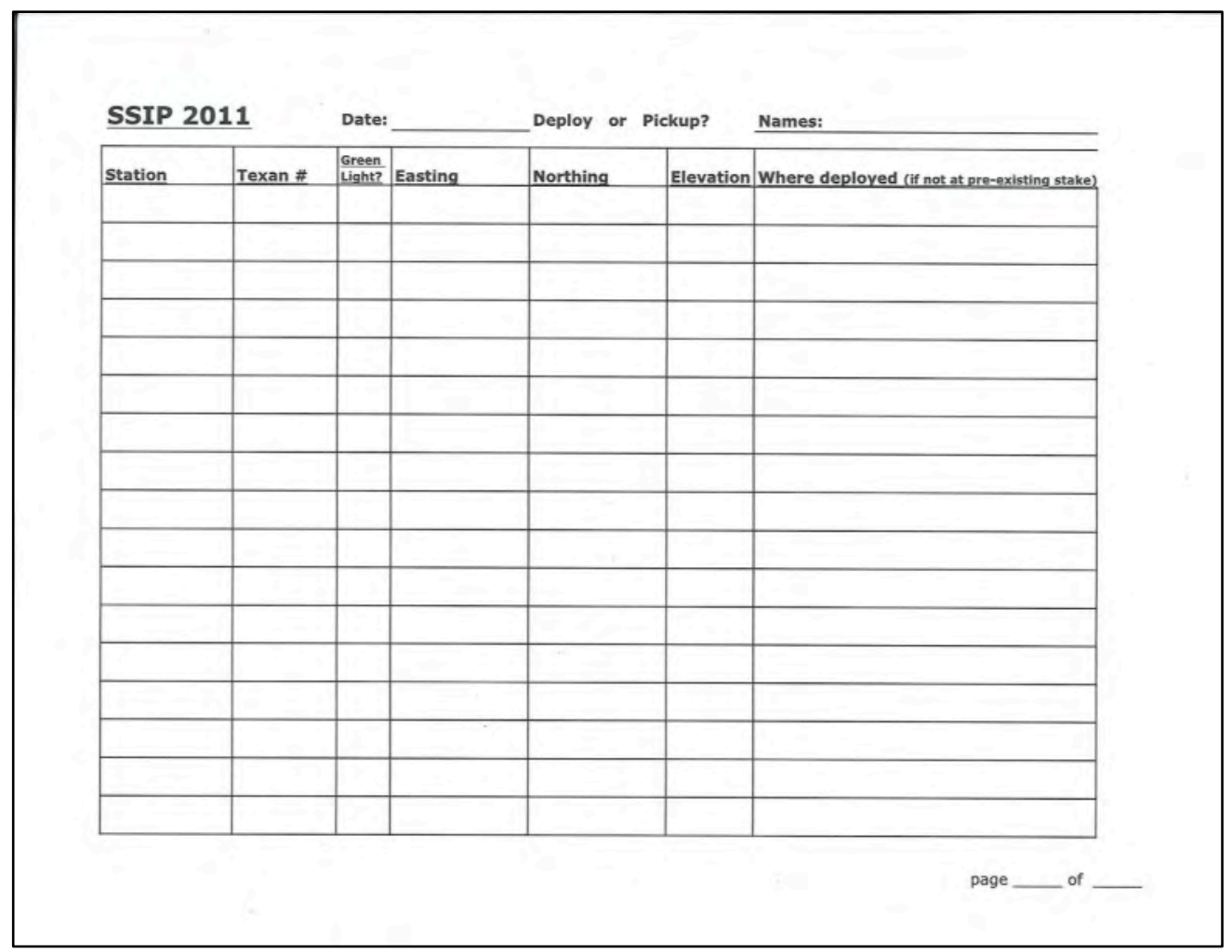

Figure 16. Texan deployment and retrieval sheet used by deployment teams.

\section{Data Processing (Cutting of Record Sections)}

After fieldwork had concluded, IRIS personnel, working from their headquarters in Socorro, New Mexico, produced SEGY files from the land seismometer data set for use by the PIs. They had to develop new software and improve existing software in order to do this. Initial shot gathers, in SEGY format, were provided in early May 2011, with additional shot gathers provided later as time permitted, and as feedback from the PIs was received. Locations were provided in meters for UTM zone $11 \mathrm{~N}$ and WGS 84 datum. For a list of shot gathers provided to PI's by IRIS, see appendix VI.

\section{Data Archiving}

Data are archived in PH5 format at the IRIS Data Management Center in Seattle, Washington. 
SALTON RT130 INSTALL SHEET

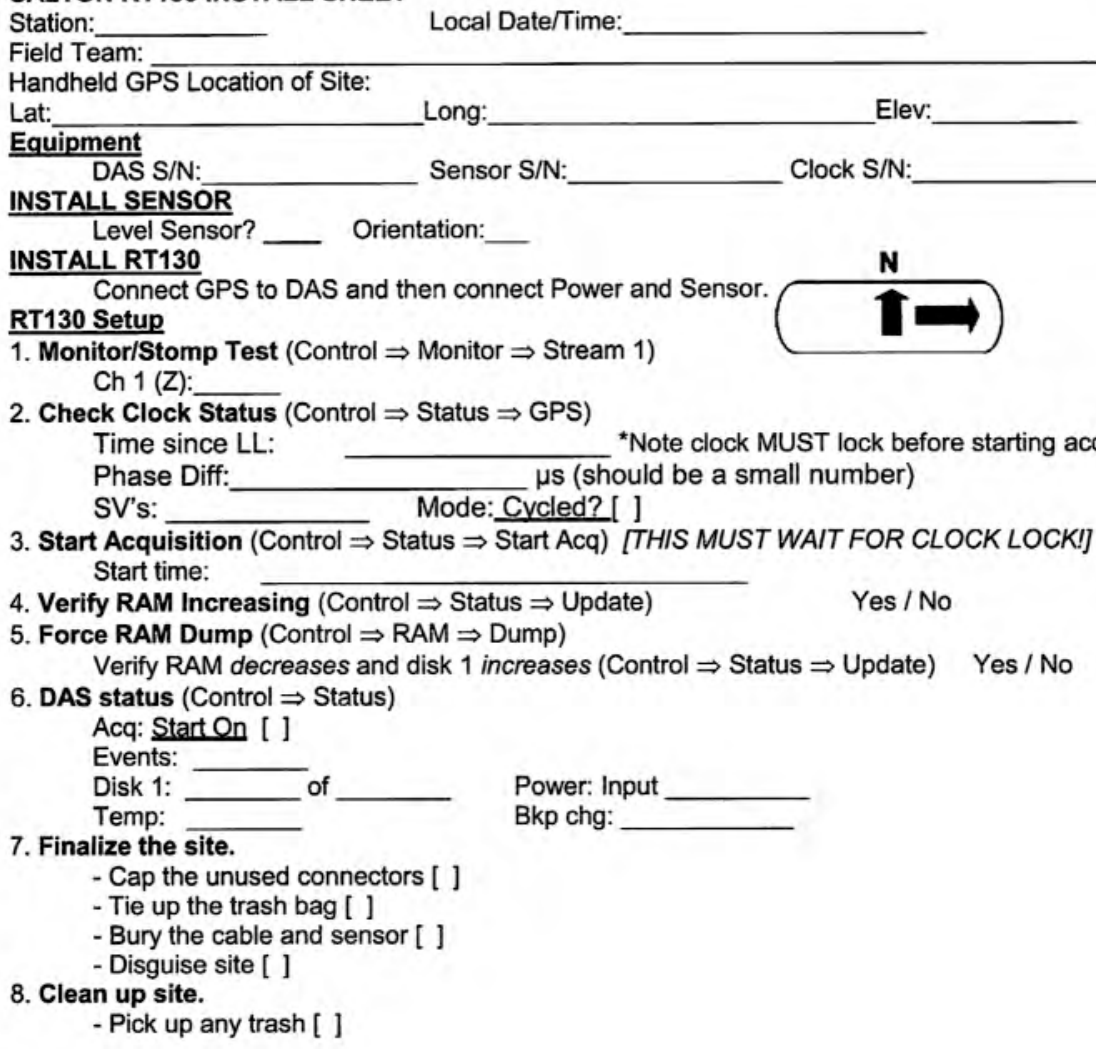

SV's:
3. Start Acquisition (Control $\Rightarrow$ Status $\Rightarrow$ Start Acq)
[THIS MUST WAIT FOR CLOCK LOCK!] Start time:

4. Verify RAM Increasing (Control $\Rightarrow$ Status $\Rightarrow$ Update) $\quad$ Yes / No

5. Force RAM Dump (Control $\Rightarrow R A M \Rightarrow$ Dump) Verify RAM decreases and disk 1 increases (Control $\Rightarrow$ Status $\Rightarrow$ Update) Yes / No

6. DAS status (Control $\Rightarrow$ Status) Acq: Start On [ ]

Events:

Disk 1: Temp:

Power: Input

7. Finalize the site.

- Cap the unused connectors [ ]

- Tie up the trash bag [ ]

- Bury the cable and sensor [ ]

- Disguise site [ ]

8. Clean up site.

- Pick up any trash [ ]

Figure 17. RT130 installation sheet used by deployment teams. 


\section{SALTON RT130 REMOVAL SHEET}

Station:

Local Date/Time:

Field Team:

Carefully approach the site. DO NOT STEP ON THE RT130!

Location of Site:

Northing:

Easting:

Elev:

Remove dirt from site with hands, not a shovel. The shovel will cut cables and damage the RT130.

Equipment

RT1 $30 \mathrm{~S} / \mathrm{N}$ :

Sensor S/N:

Clock S/N:

RT130 Setup

1. Check Clock Status (Control $\Rightarrow$ Status $\Rightarrow$ GPS)

Time since LL:

(Make sure it's less than 6 hours)

If this is less than 00:06:00:00 (6 hours) move on.

-Otherwise tap the triangle next to mode and select Continuous and hit apply.

--Next you will have to wait for the GPS to lock before moving on.

Status:

Phase Diff: $\mu \mathrm{s}$ (should be a small number)

SV's:

Mode: Cycled? [ ]

3. Stop Acquisition (Control $\Rightarrow>$ Status $\Rightarrow$ Stop Acq)

Stop time:

5. Wait for the RAM to dump to disk (can take up to a minute or two).

4. Verify RAM Goes to a small number (usually 2) (Control $\Rightarrow$ Status $\Rightarrow>$ Update) Yes / No

6. DAS status (Control $\Rightarrow$ Status)

Acq: Start Off [ ]

Events:

RAM:

of

Power: Input

Disk 1:

of

Power: Bkp

If you pull power before the disk is finished writing it can corrupt the data!!! If in doubt you can open the disk well and look at the LED next to the disk and if it is green it's OK to power down. If the LED is red DONT power down.

\section{Finalize the site.}

- Unplug everything [

- Cap the connectors [ ]

8. Clean up site.

- Fill in the hole [ ]

- Pick up any trash [ ]

- Make site look as if no one was ever there [ ]

Notes/Other Information:

Remove_RT130v20110305 PCB

Figure 18. RT130 removal sheet used by deployment teams. 


\section{Salton Sea Ocean-Bottom Seismometer Deployment and Air-Gun Operations}

\section{Ocean-Bottom Seismometers}

\section{Preparations}

The Salton Sea is a shallow saltwater lake with variable weather conditions and very poor boating infrastructure. The options for boat launching are very limited. This factor was the dominant control in determining appropriate equipment, particularly the size of the vessel and thus the length of streamers for the SSIP marine activities. Having completed several seismic experiments on the Salton Sea in the past, the Scripps/UNR group, which supervised all marine operations, was familiar with sea conditions and marinas.

Scripps/UNR contracted a marine company to operate the boat during OBS deployments. They constructed a 100-ft barge on site that had the space to set up and store the ocean-bottom seismometers (OBSs), as well as air gun compressors (fig. 19).

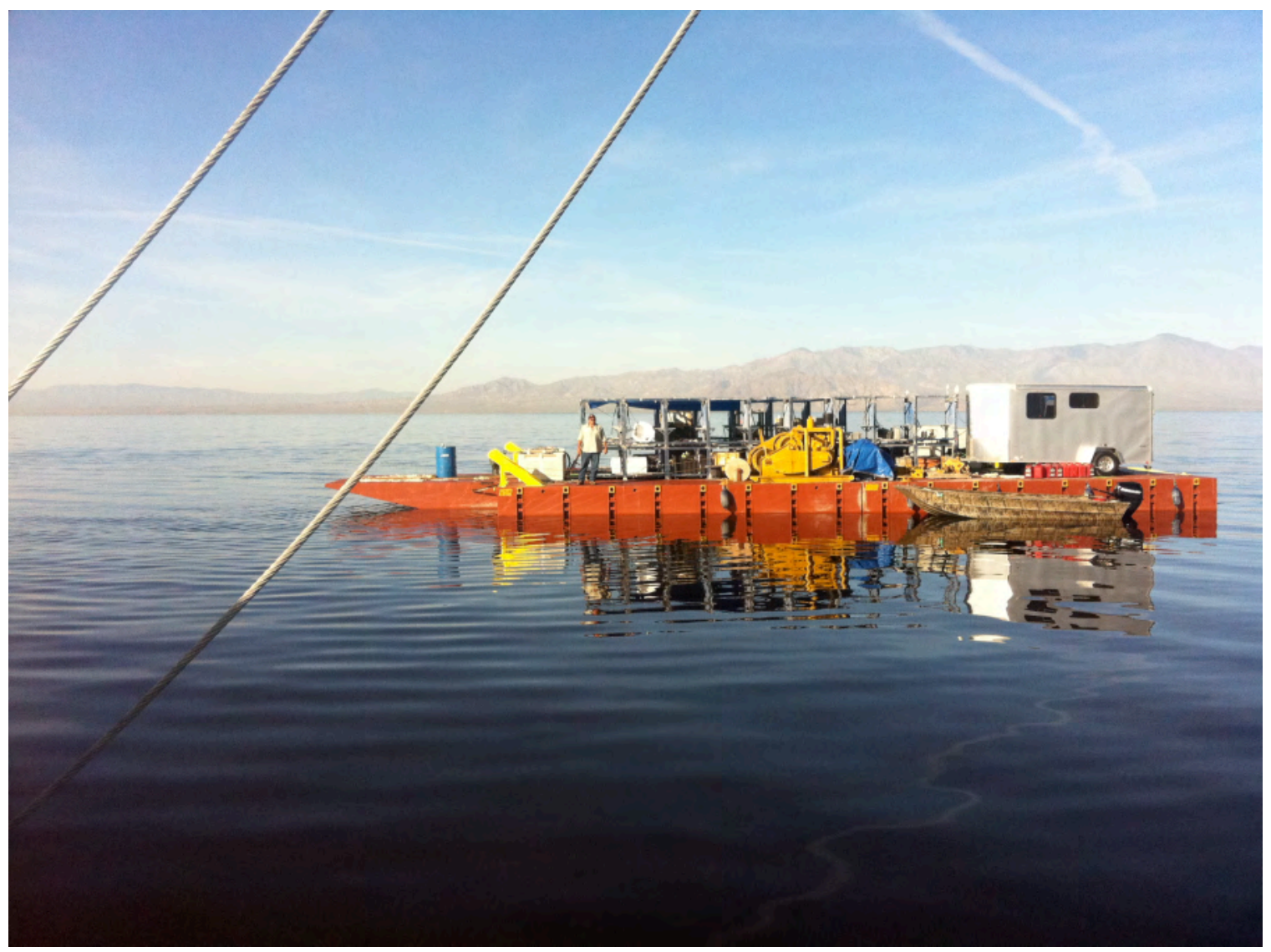

Figure 19. Photograph of barge constructed on site to accommodate the marine part of SSIP. The white trailer on the right housed the acquisition computers. OBSs were stored in the (empty) racks in the central part of the barge. The gold-colored unit in the center was the anchor winch. The compressor for the air guns was located on the other side of the barge, out of view. 
General plan for deployment.

(See appendix IV for OBS locations.)

The configuration for the OBS positions was based on previously collected data in the Salton Sea. Previous work had identified regions to try to avoid, where small amounts of gas in the sediment column had obscured seismic imaging. Scripps/UNR chose to deploy Line 1 and Line 7, in part, to match profiles where condensed high intensity radar pulse (CHIRP) seismic data had been collected by Brothers and others (2009). Line 1 was designed to highlight the southward divergence of sedimentary layers; Line 7 was designed to highlight sedimentary strata that dip perpendicular to the SAF. The OBS array in the southern portion of the Salton Sea (fig. 1) was deployed to investigate the structure of the most actively deforming portion of the upper crust beneath the sea (Brothers and others, 2009).

Deployment of OBSs was coordinated with the groups conducting the on-land shots and deployments (fig. 14b).

Instrument programming

Instruments were brought by truck from Scripps, loaded by crane onto the barge, and then assembled on site.

Programming the OBSs consisted of setting and synchronizing the logger clocks to GPS timing. Before each instrument was deployed, an acoustic unit in the OBS was programmed to respond to a specific underwater acoustic signal, known as a "call," so that the OBS could be retrieved.

Instrument deployment

Deploying an OBS unit required anchoring the barge and loading the unit onto a tow vessel. Once the GPS coordinates of the planned location were attained, the unit was simply dropped over the edge of the vessel.

Instrument pick-up and redeployment

Redeploying or moving an OBS unit required using the individual acoustic call for each instrument. Confirmation that the signal was "heard" by the OBS was followed by a "burn-wire" release of each unit from its anchor. The units could then float to the surface to be retrieved. On the barge, new anchors would be attached, and the logging unit clocks were reset prior to redeployment.

\section{Air-Gun Operations}

\section{General Plan for Air-Gun Tracks}

(See table 6 and appendix $V$ for air-gun shot times and locations.)

The general plan for air-gun tracks was to align them with lines of deployed

OBSs. Shooting generally occurred at 1-min intervals, except on the last day. A 210 -in ${ }^{3}$ generator-injector (GI) air gun was used until the last day, after which a $90-$ in $^{3}$ gun was fired at 25-second intervals. 


\section{Deployment}

Deploying the GI gun required that it be submerged 2-4 $\mathrm{m}$. The gun operated only from of the barge, thus limiting the areas that we were able to shoot, because the barge could not be operated in very shallow regions of the sea. The tow vessel used to deploy the OBSs had much greater maneuverability relative to the barge.

\section{Problems}

Prior to the last day of air-gun shooting, theft of the air compressor was attempted, which rendered the compressor inoperable - it ended up on the sea bottom! Thus, on the last day, we were forced to switch to the smaller $90-$ in $^{3}$ gun.

\section{Seismic Acquisition Systems}

Seismic data acquisition parameters for the three different seismometer systems used in SSIP are summarized in table 7.

\section{Data Processing}

Personnel from IRIS processed the data from the land seismometers and supplied them in SEGY format to all participants in SSIP in May 2011 (table 8; appendix VI). The data were supplied in the form of in-line shot gathers for each line plus shot gathers for all fan shots recorded by each line.

Shot gathers from the ends and from the middle parts of Lines 1-7 are shown in figure 20 to illustrate the data collected.

Personnel from Scripps/UNR processed the data from the OBSs and supplied them in SEGY format to all participants in SSIP. The data were supplied in the form of in-line receiver and shot gathers for Lines $1 \mathrm{M}$ and 7 (fig. 20), including gathers from airgun shots and land shots.

Feedback to IRIS, Scripps, and UNR from SSIP participants who were analyzing the data provided quality assurance on many items, from SEGY formats to missing shots and traces. 

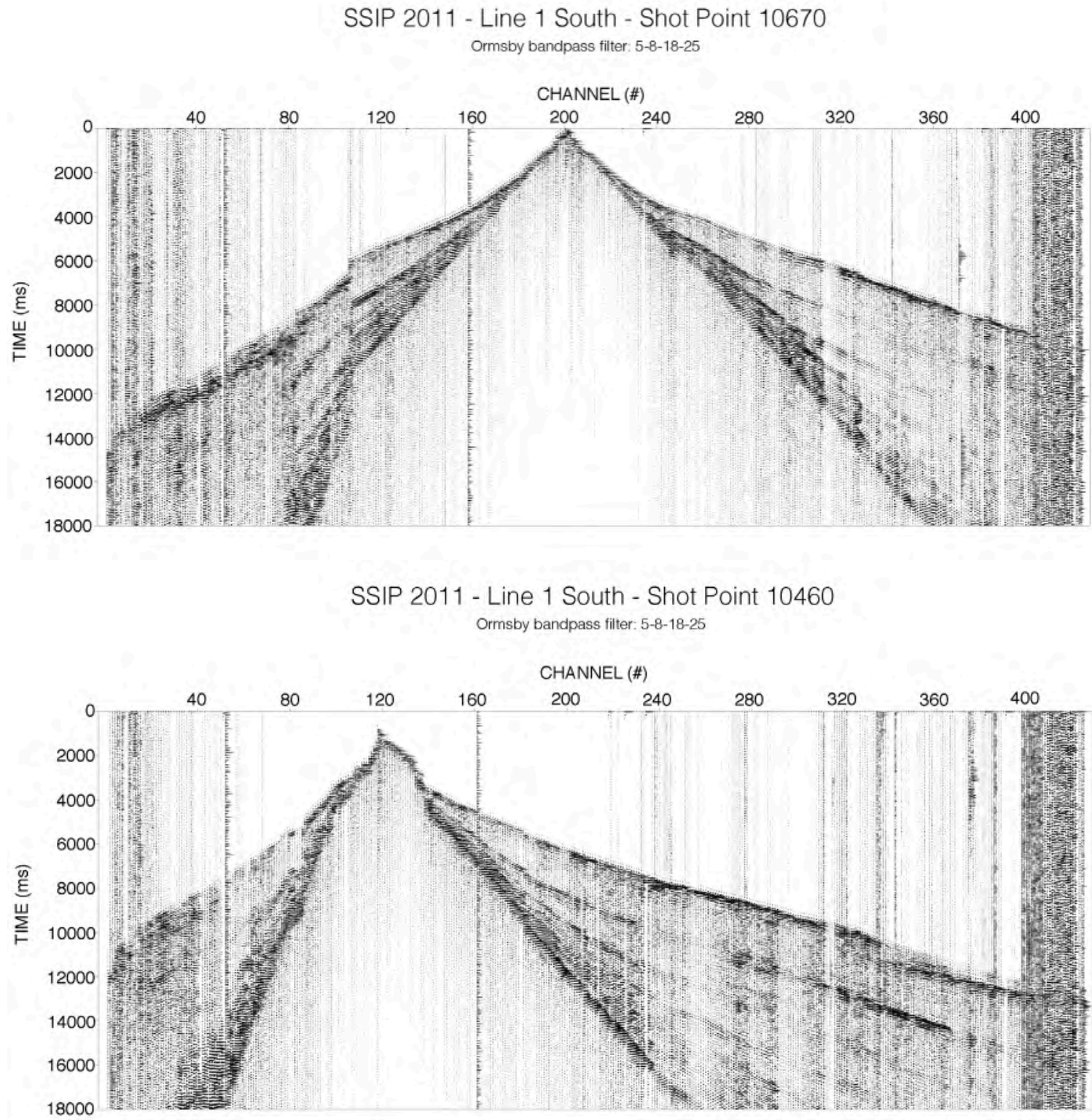

Figure 20. Shot gathers (for land shots, land seismometers, and OBSs) and receiver gathers (for airgun shots, OBSs, and land seismometers). Note that gathers for shot points 11620 and 12220 are plotted by distance rather than by channel number. Twenty-six panels shown. 
SSIP 2011 - Line 1 Marine - OBS 07 Receiver Gather

$5-40 \mathrm{~Hz}$ bandpass filter

SHOT NUMBER

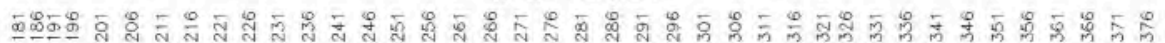

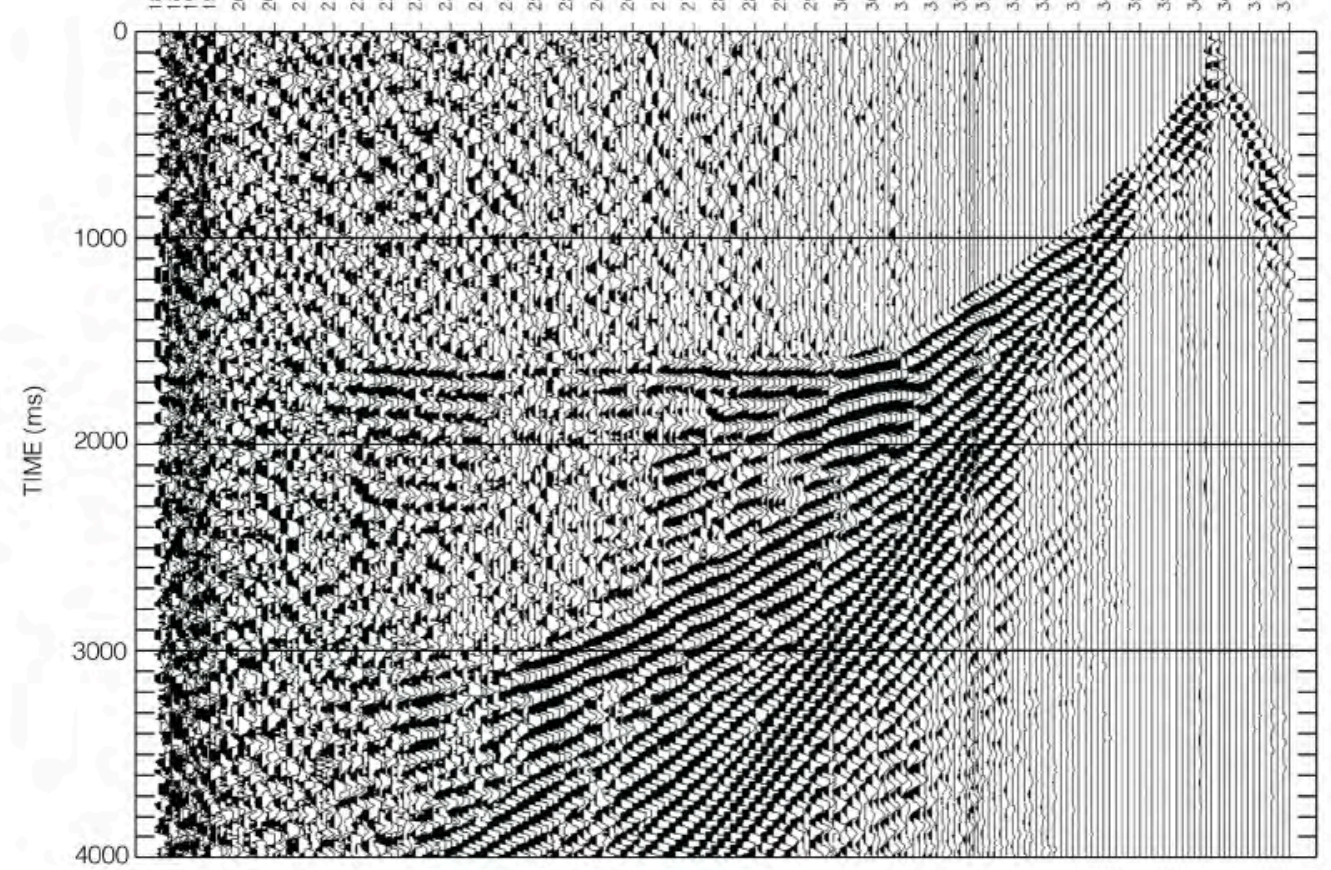

SSIP 2011 - Line 1 Marine - OBS 15 Receiver Gather $5-40 \mathrm{~Hz}$ bandpass fitter

SHOT NUMBER

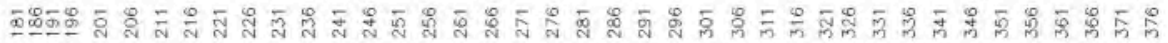

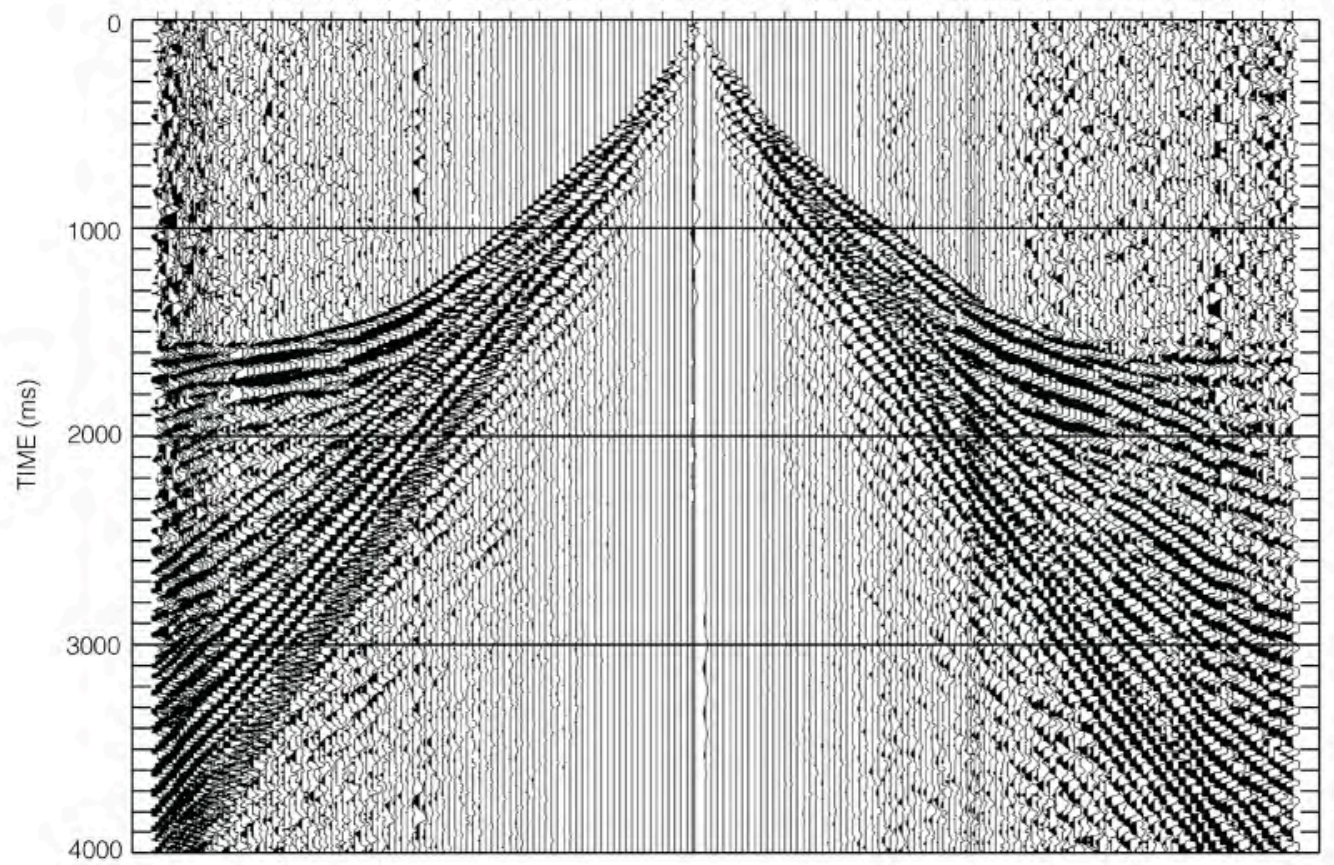

Figure 20.-Continued. 

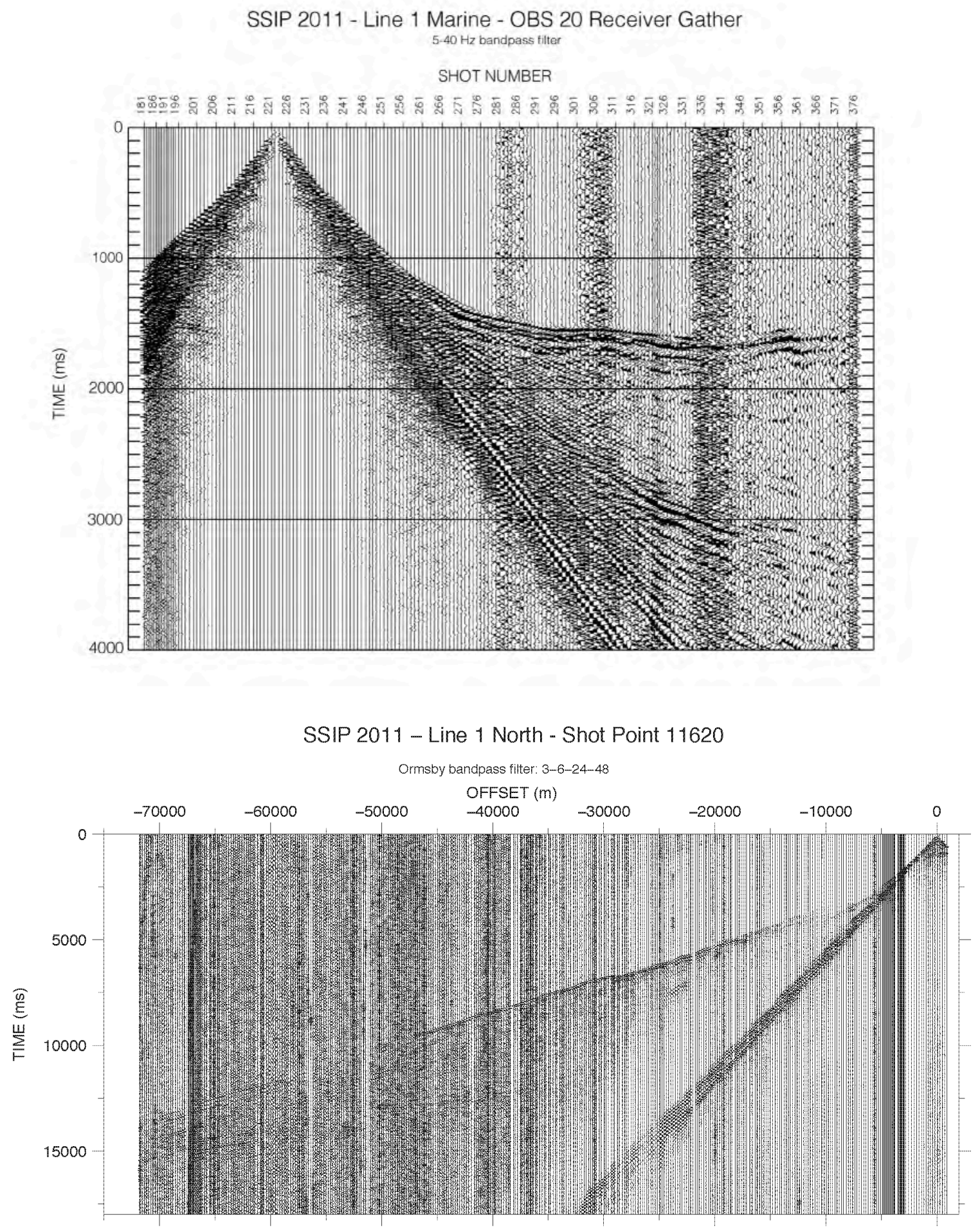

Figure 20.-Continued. 

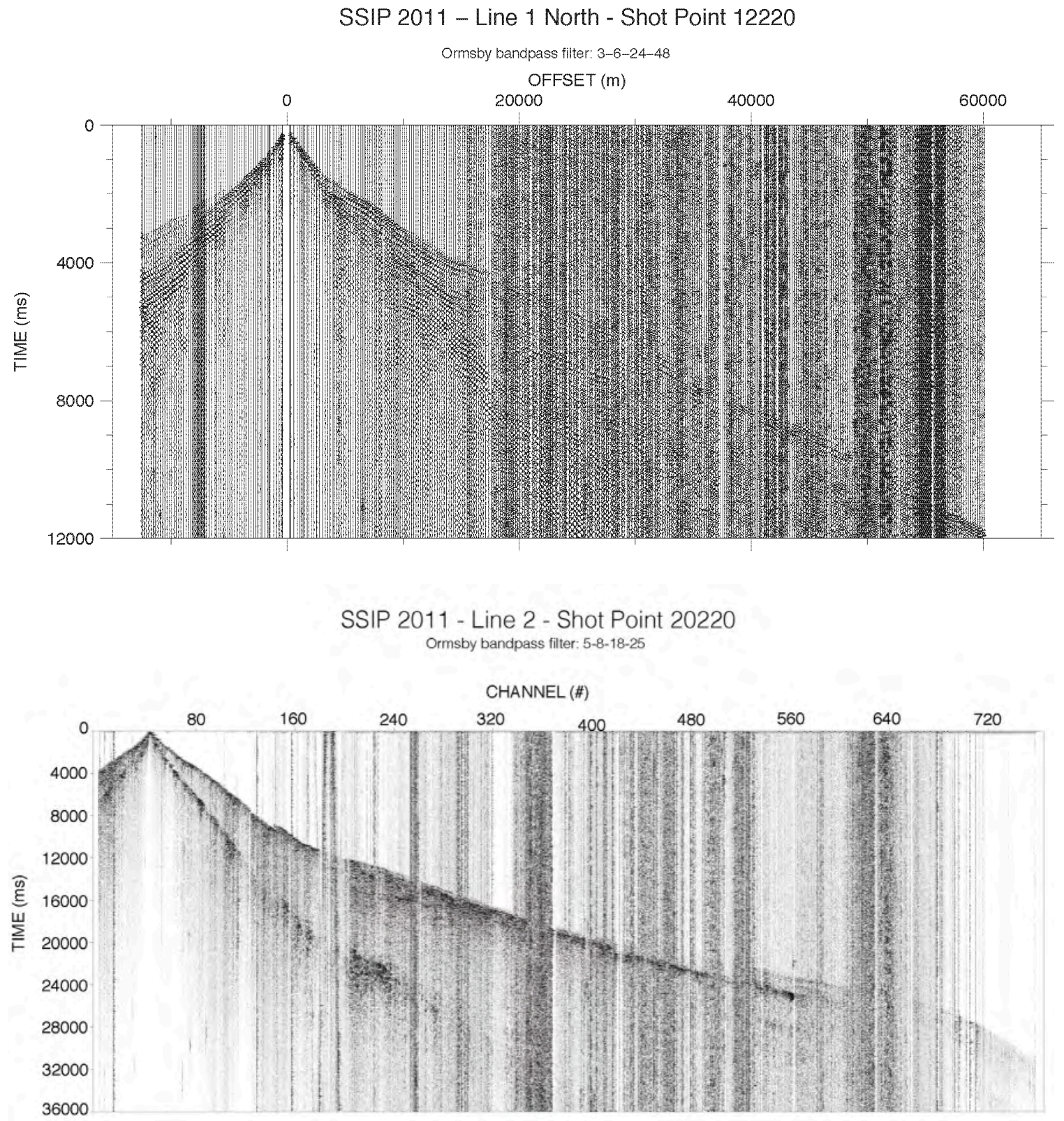

Figure 20.-Continued. 

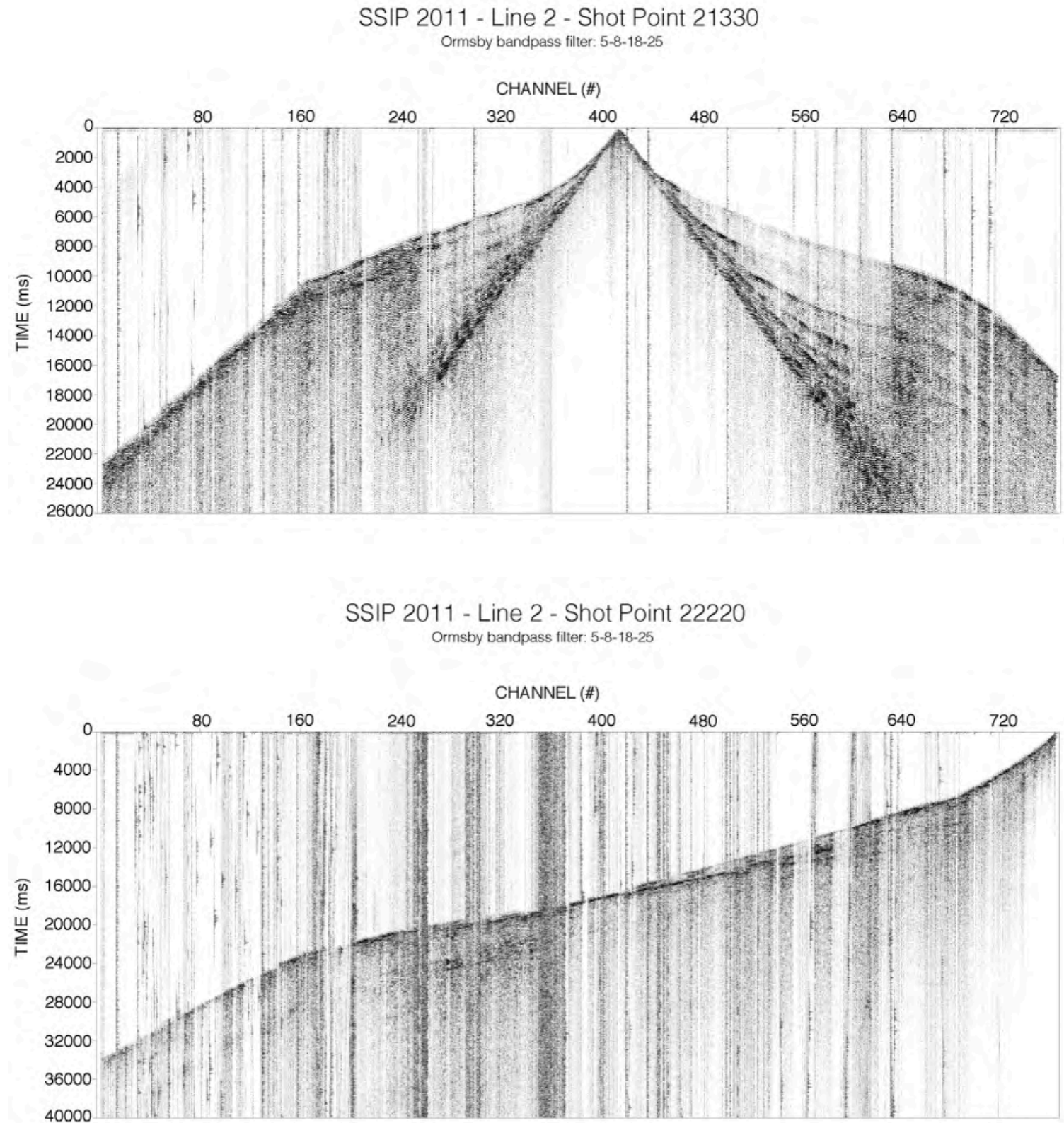

Figure 20.-Continued. 

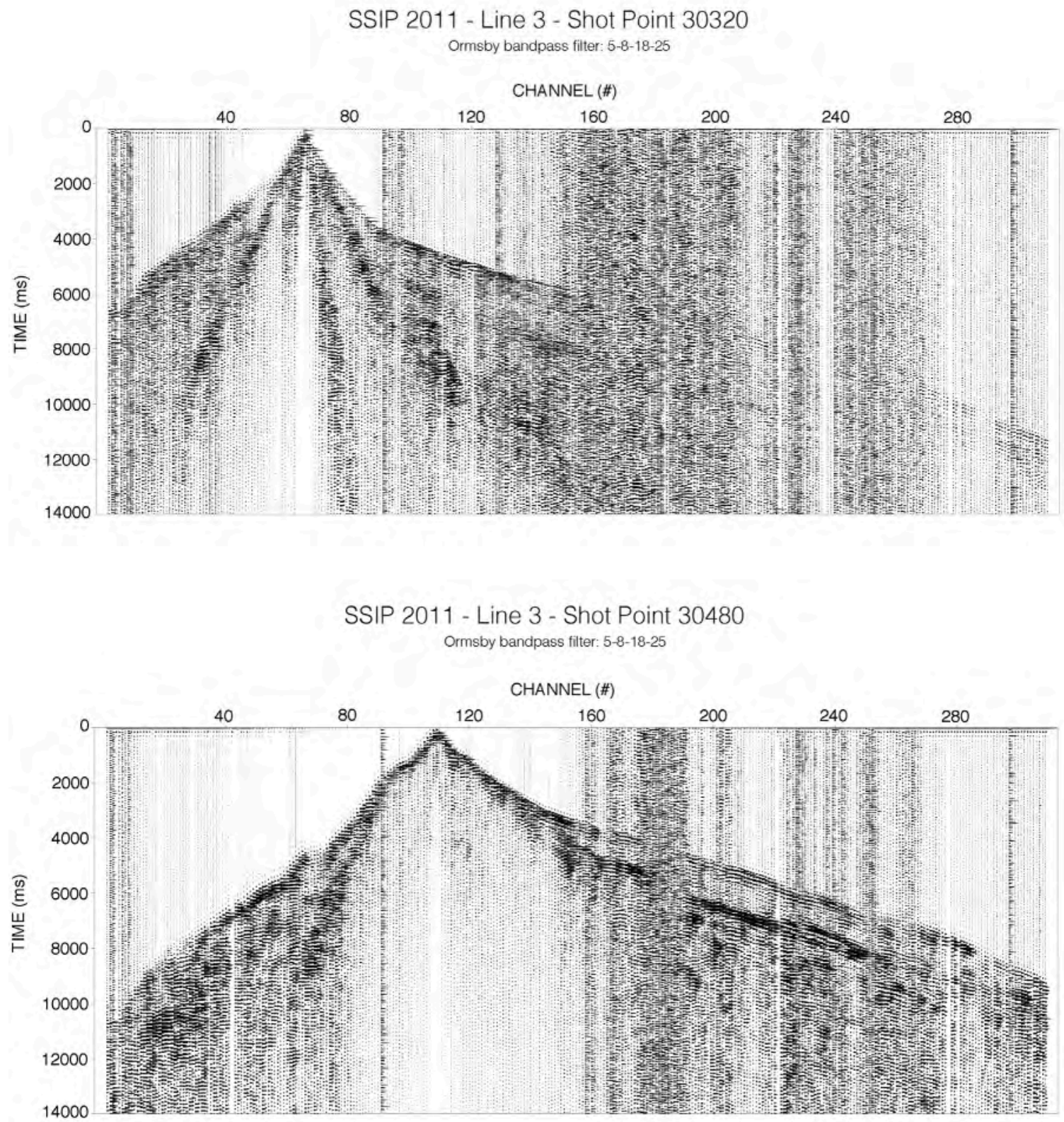

Figure 20.-Continued. 


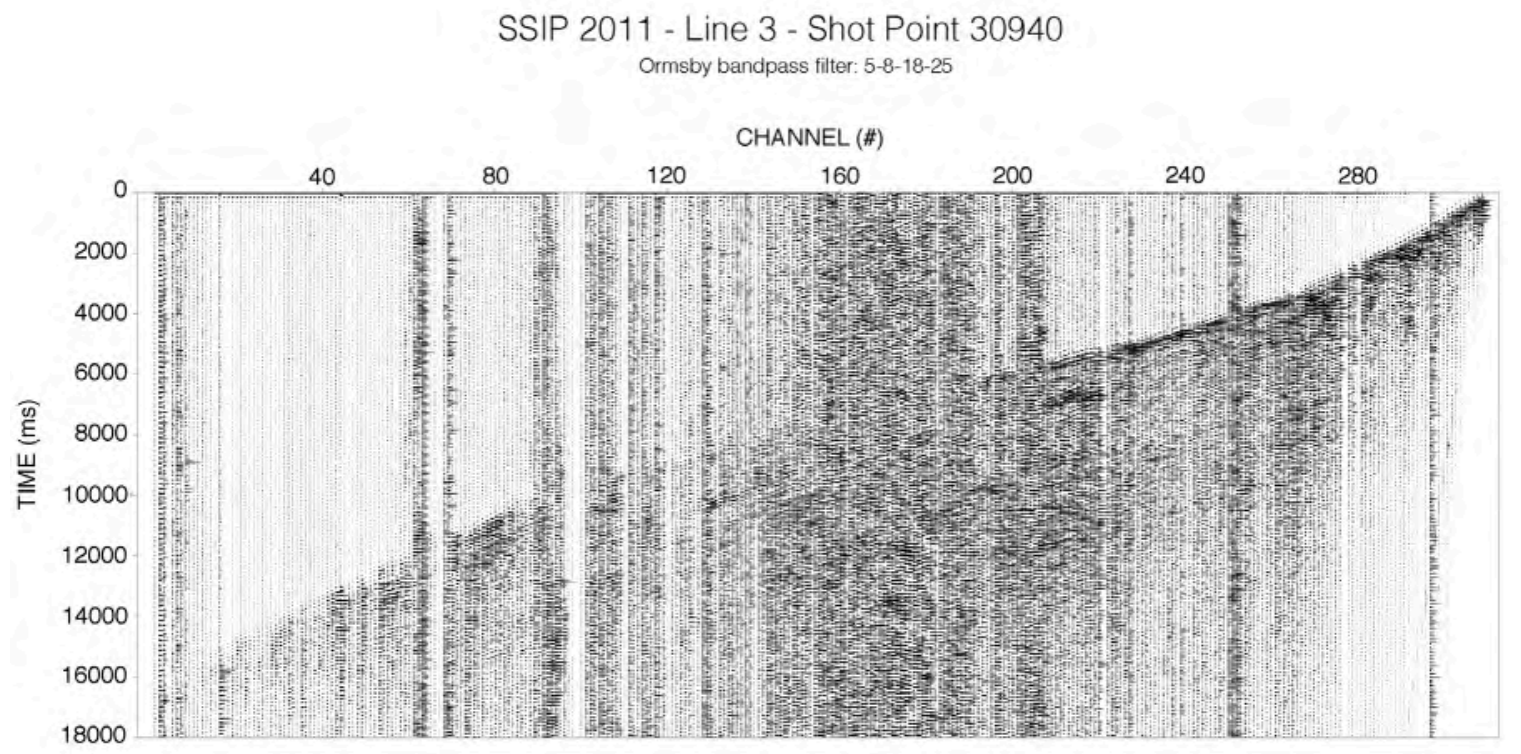

SSIP 2011 - Line 4 - Shot Point 40000

Ormsby bandpass filter: 4-8-16-32

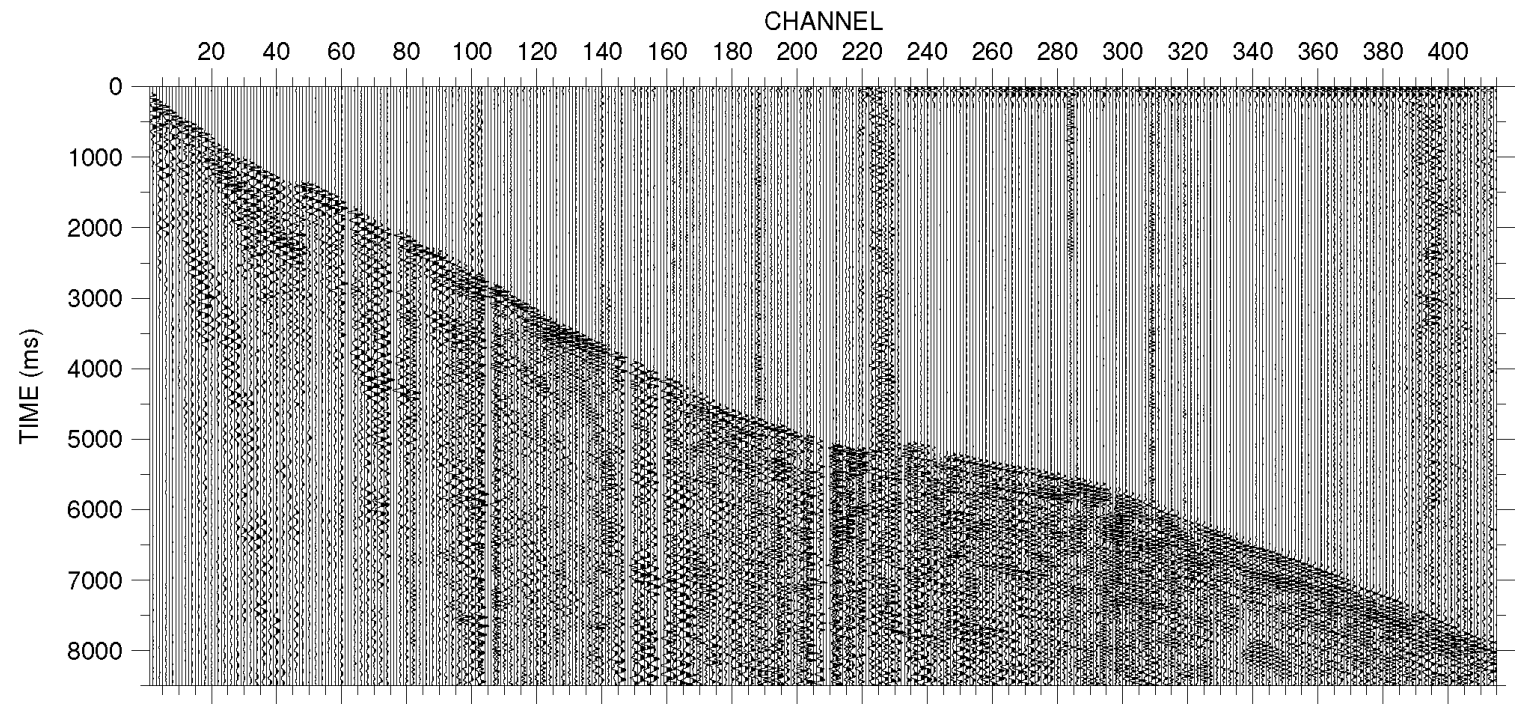

Figure 20.-Continued. 

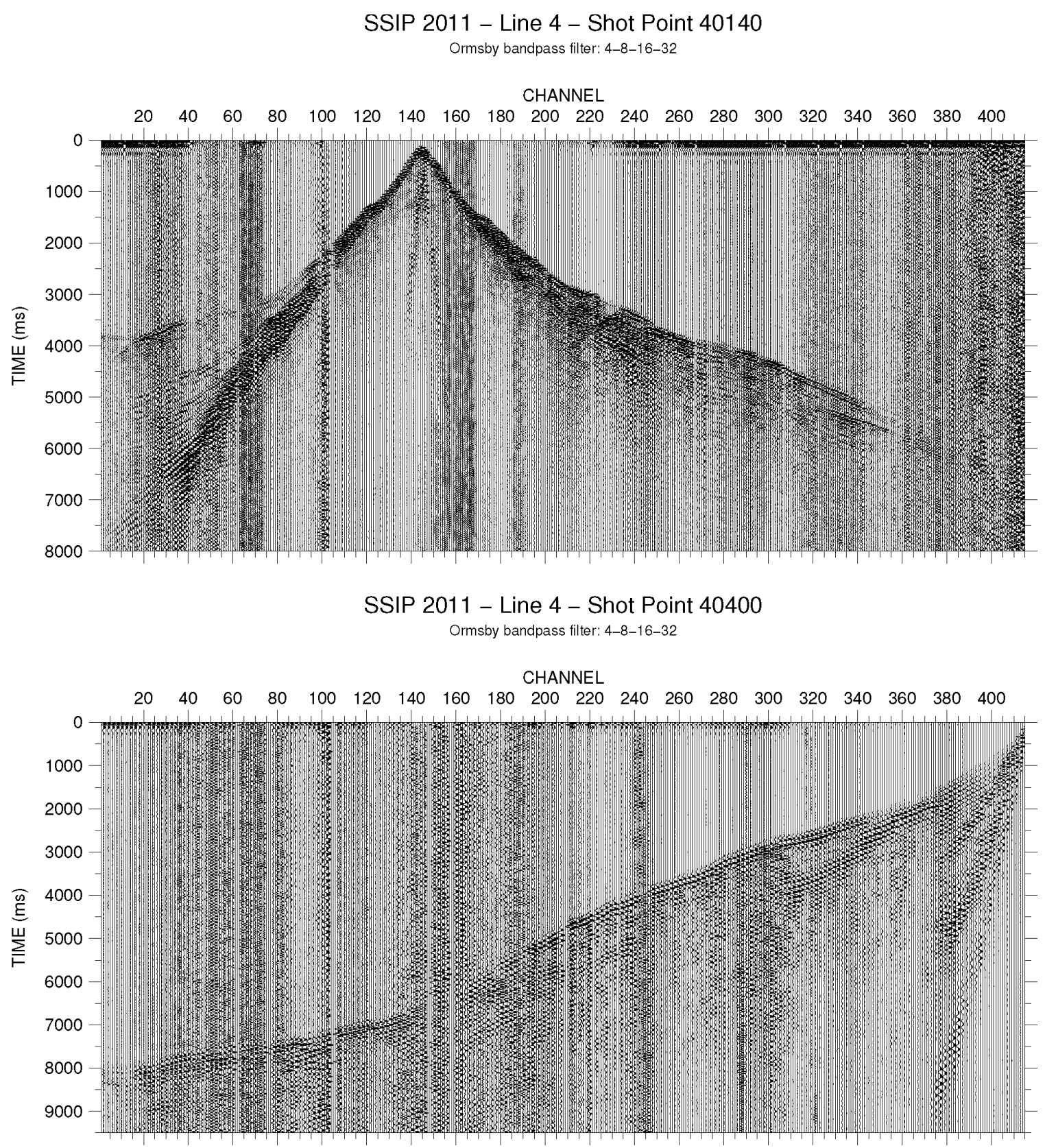

Figure 20.-Continued. 

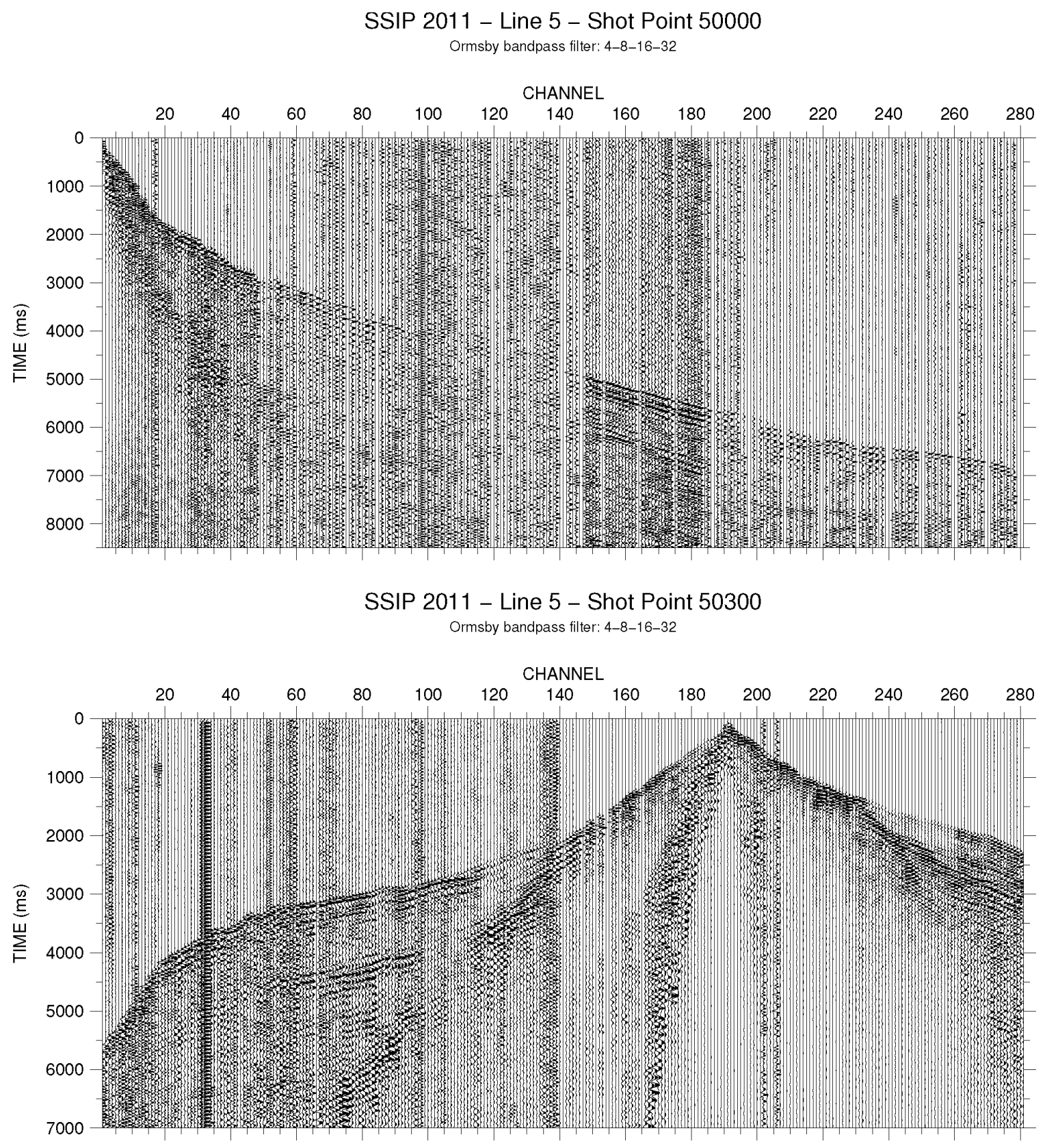

Figure 20.-Continued. 

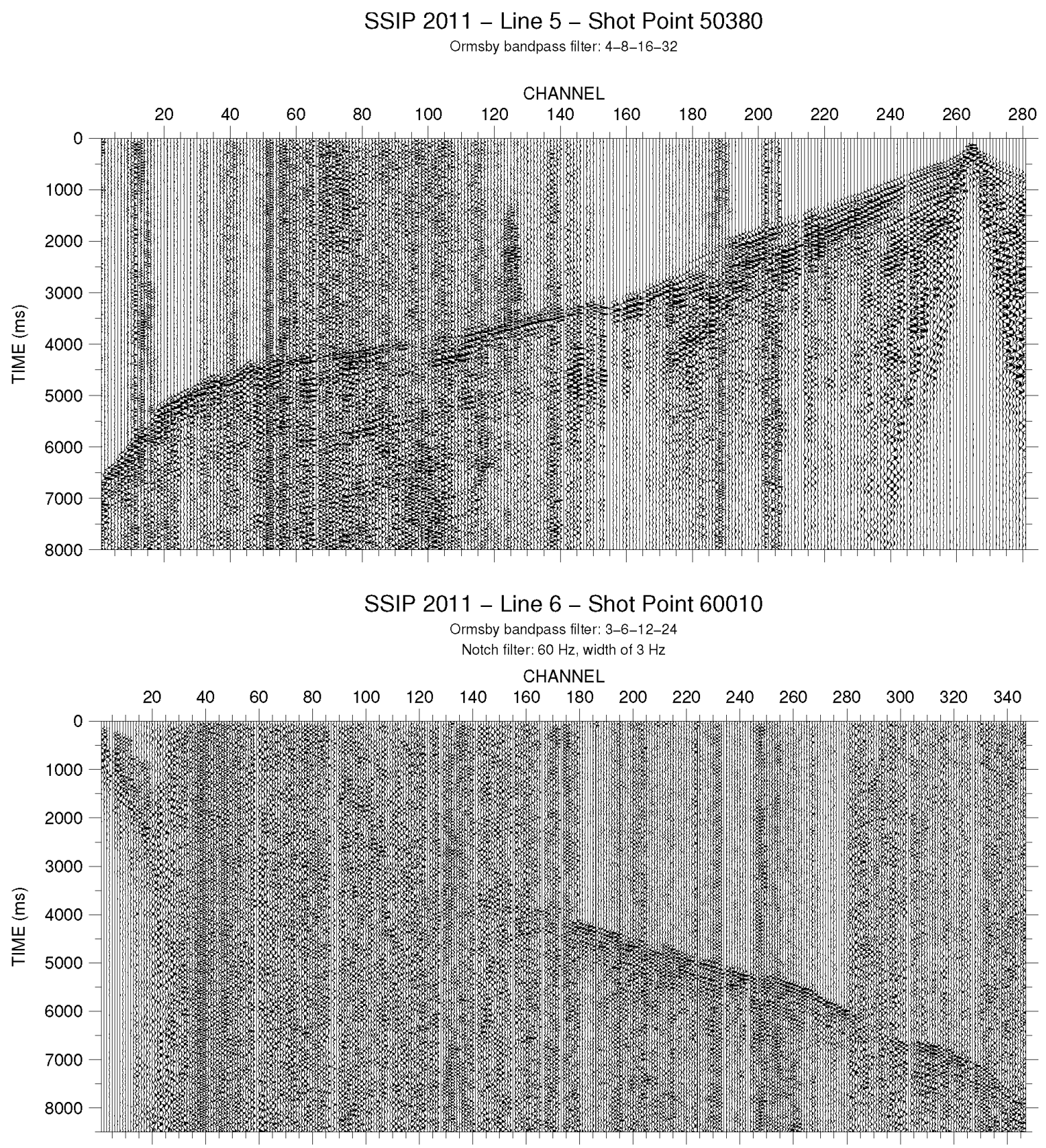

Figure 20.-Continued. 

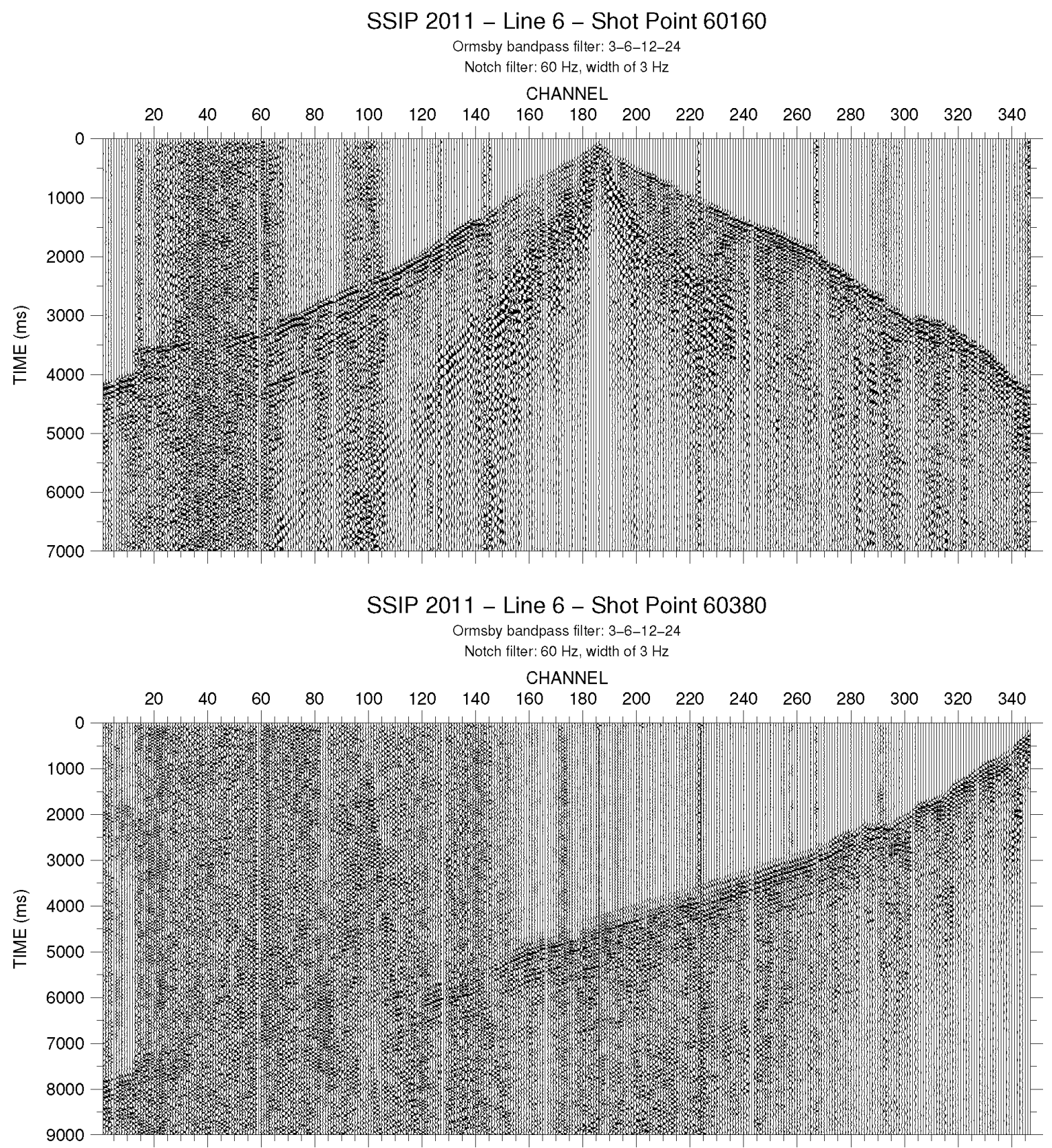

Figure 20.-Continued. 

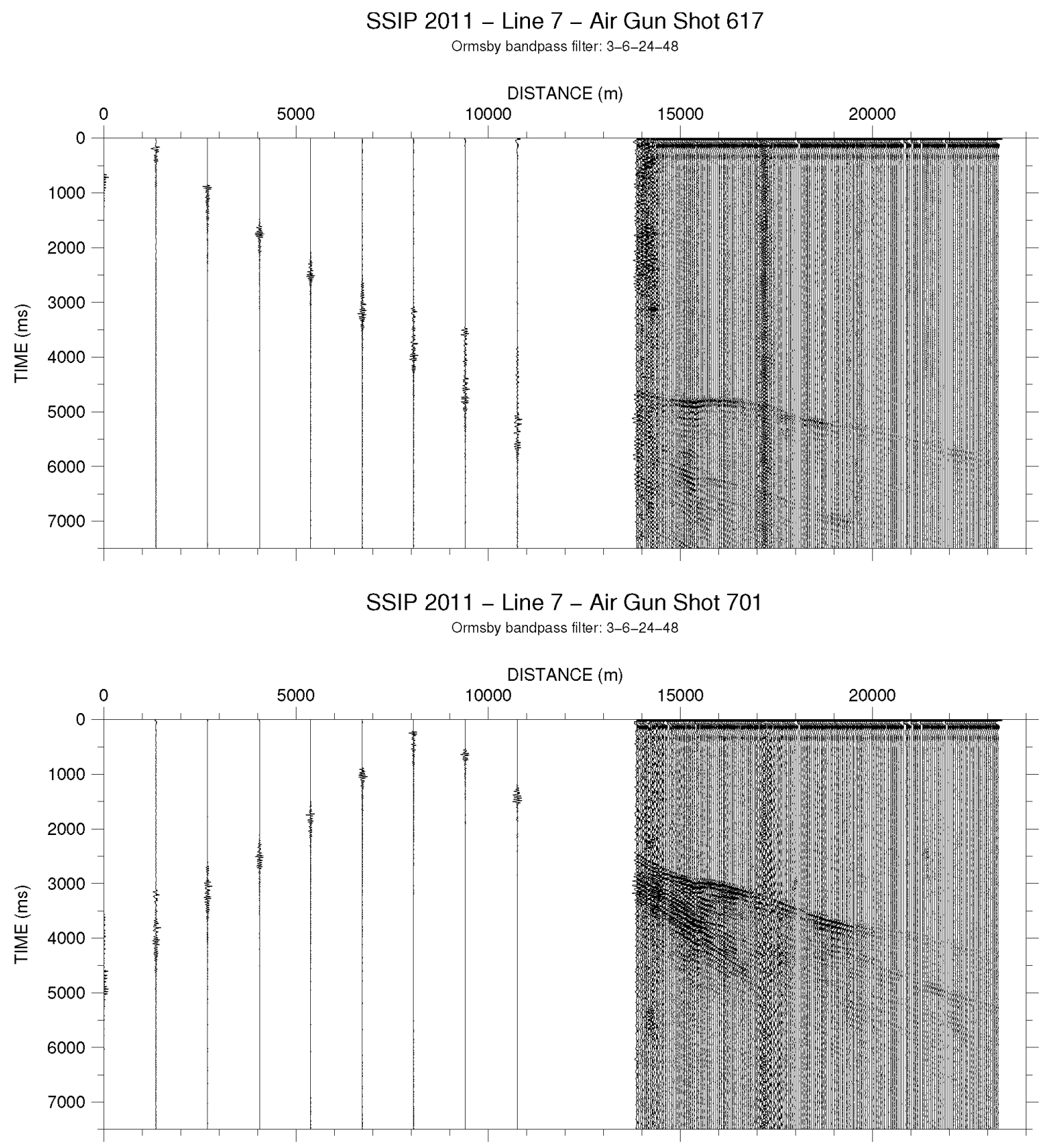

Figure 20.-Continued. 

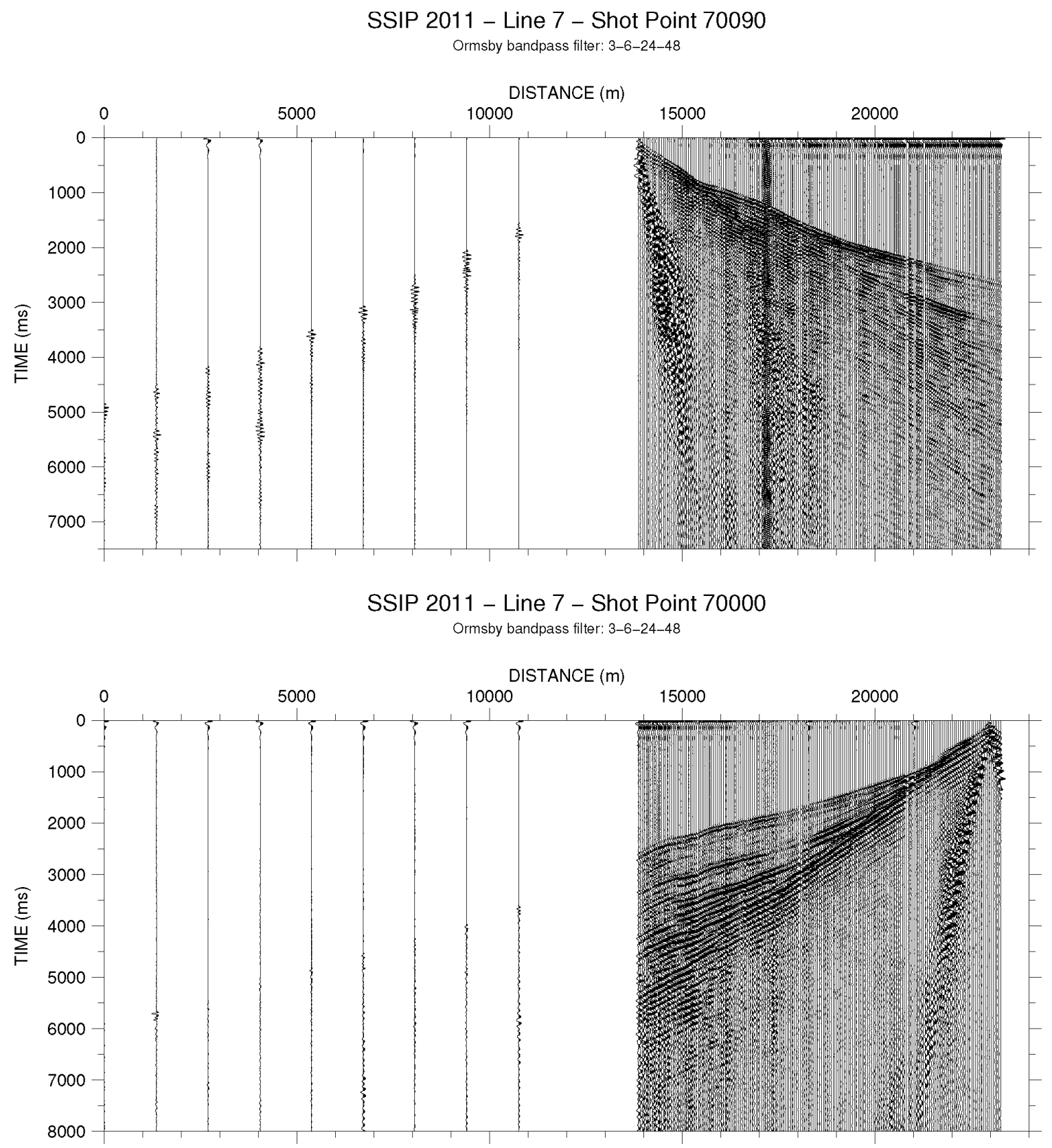

Figure 20.-Continued. 
Table 8. Shot and receiver numbers for lines 1-11.

[CV, Coachella Valley; IV, Imperial Valley]

\begin{tabular}{|c|c|c|c|c|c|c|c|c|}
\hline $\begin{array}{l}\text { Line } \\
\text { number }\end{array}$ & $\begin{array}{c}\text { Land } \\
\text { station } \\
\text { numbers }\end{array}$ & $\begin{array}{l}\text { Total } \\
\text { number } \\
\text { of land } \\
\text { stations }\end{array}$ & $\begin{array}{c}\text { OBS } \\
\text { numbers }\end{array}$ & $\begin{array}{c}\text { Total } \\
\text { number of } \\
\text { OBSs }\end{array}$ & $\begin{array}{l}\text { Land shot } \\
\text { numbers }\end{array}$ & $\begin{array}{l}\text { Total } \\
\text { number } \\
\text { of land } \\
\text { shots }\end{array}$ & $\begin{array}{l}\text { In-line air } \\
\text { gun shot } \\
\text { numbers }\end{array}$ & $\begin{array}{c}\text { Total } \\
\text { number of } \\
\text { in-line air } \\
\text { gun shots }\end{array}$ \\
\hline $\begin{array}{l}1 \mathrm{~S} \\
\text { (south) }\end{array}$ & $\begin{array}{l}100001- \\
113450\end{array}$ & 680 & & & $\begin{array}{l}10000 \text { - } \\
11100 ; 21450\end{array}$ & 21 & $1-170$ & 170 \\
\hline $\begin{array}{l}1 \mathrm{M} \\
\text { (middle) }\end{array}$ & $\mathrm{n} / \mathrm{a}$ & 0 & $1-38$ & 38 & $\mathrm{n} / \mathrm{a}$ & 0 & $1-170$ & 170 \\
\hline $\begin{array}{l}1 \mathrm{~N} \\
\text { (north) }\end{array}$ & $\begin{array}{l}118800- \\
126061\end{array}$ & 393 & & & $\begin{array}{l}11620 \text { - } \\
12342 ; 40100 \\
60120\end{array}$ & 15 & $181-376$ & 196 \\
\hline 2 & $\begin{array}{l}200000 \text { - } \\
222050\end{array}$ & 1142 & & & $20000-22220$ & 24 & & \\
\hline 3 & $\begin{array}{l}300000- \\
309310\end{array}$ & 485 & & & $\begin{array}{l}30220 \text { - } \\
30940 ; 11100 \\
20810\end{array}$ & 18 & & \\
\hline 4 & $\begin{array}{l}400000- \\
404030\end{array}$ & 413 & & & $40000-40400$ & 17 & & \\
\hline 5 & $\begin{array}{l}500000- \\
503710\end{array}$ & 286 & & & $\begin{array}{l}50000- \\
50380 ; 12000\end{array}$ & 9 & & \\
\hline 6 & $\begin{array}{l}600000- \\
604150\end{array}$ & 347 & & & $\begin{array}{l}60000 \text { - } \\
60380 ; 12300\end{array}$ & 11 & & \\
\hline 7 & $\begin{array}{l}700000- \\
700940\end{array}$ & 188 & $\begin{array}{l}70-77 \\
28\end{array}$ & 9 & $70000-70090$ & 15 & $614-747$ & 134 \\
\hline 8 & $\begin{array}{l}800000 \text { - } \\
806530\end{array}$ & 67 & & & $\begin{array}{l}81360,40080 \\
31450\end{array}$ & 3 & & \\
\hline 9 & $\begin{array}{l}900000- \\
905520\end{array}$ & 83 & & & $\begin{array}{l}\text { 30730, 40200, } \\
70090\end{array}$ & 3 & & \\
\hline $\begin{array}{l}10\left(\mathrm{CV}^{*}\right. \\
\text { array) }\end{array}$ & $\begin{array}{l}1000150 \text { - } \\
1099996\end{array}$ & 142 & & & $\mathrm{n} / \mathrm{a}$ & 0 & & \\
\hline $\begin{array}{l}11\left(\mathrm{IV}^{*}\right. \\
\text { array) }\end{array}$ & $\begin{array}{l}1101000 \text { - } \\
1116020\end{array}$ & 115 & & & $\mathrm{n} / \mathrm{a}$ & 0 & & \\
\hline
\end{tabular}




\section{Shot Site Remediation}

Our cleanup effort began in April 2011, 1 month after shooting had concluded. Three USGS employees and two contracted helpers (plus up to three other intermittent helpers from USGS and/or Caltech) focused on remediating shot sites until the end of June 2011, when high temperatures (greater than $110^{\circ} \mathrm{F}$ ) prevented us from safely continuing work at shot sites. USGS employees remediated the last few shot sites in August 2011, thus completing the cleanup effort.

In the SSIP permits, which landowners and land managers signed and returned to USGS prior to drilling activity, it was stated that steel casing would be cut and removed 2 $\mathrm{ft}$ below grade. Upon request, or as cleanup personnel deemed necessary, steel casing was removed to as much as $5 \mathrm{ft}$ below grade. During drilling, most shot holes were cased (3/8-in. thick steel, 6- or 8-in. diameter casing) to the ground surface level, or to a few inches above the ground surface level. However, during shooting, the steel casing did not always remain in place. In some instances, casing sunk between the times of shooting and cleanup. By the time we visited all sites during the cleanup phase, the casings had sunk more than $2 \mathrm{ft}$ below grade at 30 sites, and at least some parts of casings were ejected from the holes at 5 sites (table 9). Therefore, cleanup activities varied somewhat, but generally consisted of digging out the steel casing (by hand or using a Bobcat ${ }^{\circledR}$ loader); cutting the casing with a plasma cutter (usually at $2.5-3 \mathrm{ft}$ below grade); filling in empty shot holes and/or craters with bentonite, gravel, sand and/or dirt; raking out tracks caused by SSIP activities; and removing flagging used to help crew members locate shot holes. 
Table 9. Cleanup details for 6 boreholes. Details for all boreholes are available in appendix VIII.

\begin{tabular}{|c|c|c|c|c|c|c|c|c|c|c|c|c|}
\hline $\begin{array}{c}\text { Shot } \\
\text { point } \\
\text { number }\end{array}$ & $\begin{array}{c}\text { Casing } \\
\text { sunk }> \\
2 \mathrm{ft}\end{array}$ & $\begin{array}{l}\text { Casing } \\
\text { stayed } \\
\text { in place } \\
(+/-2 \mathrm{ft})\end{array}$ & $\begin{array}{c}\text { Casing } \\
\text { up }>2 \\
\mathrm{ft}\end{array}$ & $\begin{array}{r}\text { Casing } \\
\text { ejected }\end{array}$ & Ownership & $\begin{array}{c}\text { Special } \\
\text { instructions; } \\
\text { notes }\end{array}$ & $\begin{array}{c}\text { Cleanup } \\
\text { date(s) }\end{array}$ & Cleanup crew members: & $\begin{array}{c}\text { Site condition upon arrival (i.e. tracks, crater } \\
\text { dimensions, casing height relative to grade, drill } \\
\text { cuttings present, etc.) vs. after cleanup (photos taken } \\
\text { before and after). (See also Table 5) }\end{array}$ & $\begin{array}{c}\text { Steel } \\
\text { casing } \\
\text { removed }\end{array}$ & $\begin{array}{c}\text { Bentonite } \\
\text { used }\end{array}$ & $\begin{array}{c}\text { Fill } \\
\text { material } \\
\text { used }\end{array}$ \\
\hline $1000 \mathrm{~d} 1$ & \multirow{3}{*}{1} & & & & BOR & & \multirow{3}{*}{$4 / 8 / 11$} & \multirow{3}{*}{$\begin{array}{l}\text { Contractor: Zeller's Excavating and Paving } \\
\text { (B.T.Z. Inc.), Yuma, AZ }\end{array}$} & \multirow[t]{3}{*}{$\begin{array}{l}\text { Two holes collapsed immediately after shooting. } \\
\text { Shooters collapsed the third hole manually in order to } \\
\text { prevent collapse at a later time. Infilling of these holes } \\
\text { was contracted out in order to complete remediation as } \\
\text { soon as possible. }\end{array}$} & 0 & 0 & $\begin{array}{l}\text { Imported } \\
\text { sand }\end{array}$ \\
\hline $1000 \mathrm{~d} 2$ & & & & & BOR & & & & & 0 & 0 & $\begin{array}{l}\text { Imported } \\
\text { sand }\end{array}$ \\
\hline $1000 \mathrm{~d} 3$ & & & & & BOR & & & & & 0 & 0 & $\begin{array}{l}\text { Imported } \\
\text { sand }\end{array}$ \\
\hline 1046al & \multirow{2}{*}{1} & & & & BLM & $\begin{array}{l}\text { Call border } \\
\text { patrol to cross } \\
\text { Check Bridge }\end{array}$ & \multirow{2}{*}{$\begin{array}{c}4 / 18 / 11 \text { and } \\
5 / 26 / 11\end{array}$} & \multirow{2}{*}{$\begin{array}{l}\text { 4/18: R. Sickler, C. Criley; 5/26: Rose, } \\
\text { Barrows, Pyramid Construction }\end{array}$} & \multirow{2}{*}{$\begin{array}{l}\text { Site condition upon arrival: Open crater } 45^{\prime} \text { x } 50^{\prime} \times 15^{\prime} \\
\text { deep in soft sand; Mediation taken: April 18: Added } \\
100^{\prime} \text { of silt fence to keep out tortoises. Needs } 25^{\prime} \text { more. } \\
\text { Located fence where bushes could fill in the gaps as well } \\
\text { as possible. May 26: Pyramid Construction filled in } \\
\text { crater with imported sand. C. Barrows on-site biologist. } \\
\text { E. Rose overseeing job. After Pyramid Construction } \\
\text { finished job, C. Barrows and E. Rose knocked down } \\
\text { some small berms. The crater had been filled in to grade } \\
\text { with } 10-15 \text { truck loads of fill sand/dirt and then wetted } \\
\text { down and driven over. They then fixed up the roads a bit } \\
\text { before leaving the area. }\end{array}$} & 0 & 0 & $\begin{array}{l}\text { Imported } \\
\text { sand }\end{array}$ \\
\hline $1046 \mathrm{a} 2$ & & & & & BLM & $\begin{array}{l}\text { Not enough silt } \\
\text { fence to enclose } \\
\text { crater! }\end{array}$ & & & & 0 & 0 & $\begin{array}{l}\text { Imported } \\
\text { sand }\end{array}$ \\
\hline $1051 \mathrm{a}$ & 1 & & & & private & & $5 / 6 / 11$ & $\begin{array}{l}\text { C.Criley, E. Rose, C. Slayday-Criley, S. } \\
\text { Skinner, C. Barrows, M.J. Perez, J. Murillo }\end{array}$ & $\begin{array}{l}\text { Couldn't see casing. Hole } \sim 3 \mathrm{ft} \text { deep. Filled in hole with } \\
\text { local sand, dirt quickly. }\end{array}$ & 0 & 0 & $\begin{array}{c}\text { Local } \\
\text { material }\end{array}$ \\
\hline
\end{tabular}


On BLM-managed land, endangered species (particularly the desert tortoise and flat-tailed horned lizard) were of utmost concern. On sites managed by the BLM El Centro office, a professional biologist was required to oversee all activities performed on BLM land, including cleanup. In the Coachella Valley, however, the BLM Palm Springs office designated one of our crewmembers as the biological monitor (mostly concerned with the desert tortoise). It was not until the cleanup of Line 6 that we finally saw a desert tortoise! We waited while it walked slowly off of the road in Little Morongo Canyon, glad that it was not near any of our shot holes. On Line 6 in Little Morongo Canyon, the BLM also relocated dead cholla cacti, setting them in upright positions in the active washes or on unofficial side trails to deter off-road recreationalists (fig. 21). Because our shot points were off of the road and/or in these active washes, every time we accessed one of these shot points, we had to move and reposition the dead cholla.

In total, 123 permitted shot sites were remediated as needed. Two subcontractors were hired in order to remediate two shot sites (10000 and 10460; table 9) where blasts created craters too big to be cost-effectively filled in by USGS personnel. Additionally, a special cleanup crew had to cautiously remediate a site (1172a) where a landowner miscommunication prevented PIs from detonating a shot that had already been drilled and loaded.

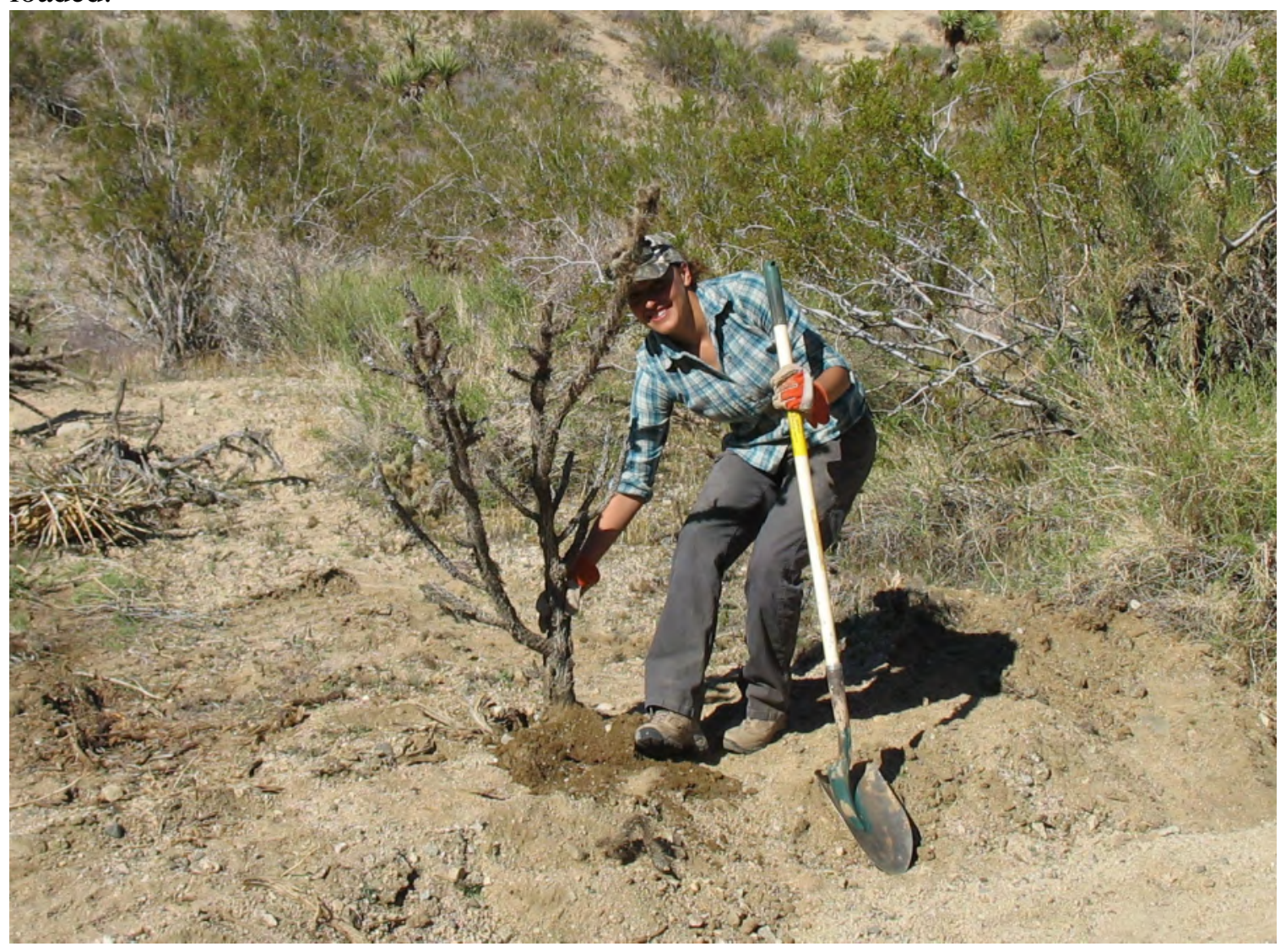

Figure 21. Photo of a U.S. Geological Survey crew member "replanting" dead cholla cacti on Bureau of Land Management land along Line 6. Positioning the dead cholla in upright positions along Little Morongo Canyon Road is intended to deter off-road recreationalists. 


\section{KMZ Summary Files}

The KMZ files in appendix VII show the locations of all land shot points, air-gun shot points, land receivers, and OBSs (online only at http://pubs.usgs.gov/of/2013/1172/.). Hovering a computer mouse over each point in these files will give the shot point or receiver number for that point. In this KMZ file, the Coachella and Imperial Valley arrays ("lines" 10 and 11) are numbered as "lines" 11 and 12, respectively. For example, if you were to see a Texan location named 1100000 (referring to line 11) in Google Earth ${ }^{\mathrm{TM}}$, it would actually refer to what is named $\mathbf{1 0 0 0 0 0 0}$ (referring to line 10) elsewhere in this report and in the data archives.

\section{Acknowledgments}

We would like to acknowledge the following individuals, organizations, and businesses (table 10). Not listed are the more-than-100 landowners who permitted us to put one or more shot points or receivers on their private property. We are grateful to the large number of persons and entities who granted us permission to use their properties; many were enthusiastic and very helpful. Without the support and cooperation of these permitters this project would have been impossible.

Table 10. Acknowledgments.

\begin{tabular}{ll}
\hline & Federal organizations \\
\hline J.D. Adams & NAF El Centro \\
Doug Barnum & BLM Palm Springs Field Office \\
Carvel Bass & USGS Salton Sea Scence Office \\
Jenny Blanchard & US Army Corps of Engineers \\
David Busch & BLM El Centro Field Office \\
Donna Clinton & USGS Pacific Southwest Area \\
Jimmie Collins & BLM El Centro Field Office \\
Lee Case & NAF El Centro \\
Mark Cohen & USGS Salton Sea Science Office \\
Chris Dalu & US Army Corps of Engineers \\
Corice Farrar & BLM Palm Springs Field Office \\
Mary Ellen Finch & US Army Corps of Engineers \\
Greg Hill & Marine Corps Air Station Yuma \\
Heidi Hoggan & BLM Palm Springs Field Office \\
Birgit Hoover & USFS San Bernardino National Forest \\
Tom Jordan & BLM Barstow Field Office \\
John Kalish & Director, Southern California Earthquake \\
Kate Kitchell & Center. Funding for student volunteers \\
James Mace & provided from the Director's Fund. \\
& BLM Palm Springs Field Office \\
USGS Southwest Biological Science \\
Center \\
US Army Corps of Engineers
\end{tabular}




\begin{tabular}{|c|c|}
\hline Susan Marcus & USGS Native American Tribal Liaison \\
\hline Cheryl Martinez & BLM Palm Springs Field Office \\
\hline $\begin{array}{l}\text { National Science } \\
\text { Foundation }\end{array}$ & $\begin{array}{l}\text { EarthScope and Margins Programs: Grants } \\
\text { OCE-0742253, OCE-0742263, and OCE- } \\
0927446 \text { funded approximately half of this } \\
\text { project }\end{array}$ \\
\hline Richard Nagle & US Army Corps of Engineers \\
\hline Jim O'Connor & BOR Yuma Area Office \\
\hline Ronald Pearce & U.S. Marine Corps \\
\hline Anna Pinnell & BOR Yuma Area Office \\
\hline Jorge Rivas & NAF El Centro \\
\hline Jim Robinette & NAF El Centro \\
\hline Lori Rosenthal & USFS San Bernardino National Forest \\
\hline Samuel Sandoval & NAF El Centro \\
\hline John Salguaro & USN Camp Billy Machen \\
\hline Joyce Schlachter & BLM Palm Springs Field Office \\
\hline $\begin{array}{l}\text { Chris Schoneman and his } \\
\text { staff }\end{array}$ & $\begin{array}{l}\text { USFWS Sonny Bono Salton Sea National } \\
\text { Wildlife Refuge }\end{array}$ \\
\hline Carrie Simmons & BLM El Centro Field Office \\
\hline $\begin{array}{l}\text { Southern California } \\
\text { Earthquake Center }\end{array}$ & $\begin{array}{l}\text { NSF Cooperative Agreement EAR- } \\
0529922 \text { and USGS Cooperative } \\
\text { Agreement 07HQAG0008. The SCEC } \\
\text { contribution number for this paper is } 1797 .\end{array}$ \\
\hline Daniel Steward & BLM El Centro Field Office \\
\hline Timothy Symanski & Marine Corps Air Station Yuma \\
\hline Jennifer Thomas & $\begin{array}{l}\text { Bureau of Indian Affairs, Pacific Regional } \\
\text { Office }\end{array}$ \\
\hline R.J. Van Sant & U.S. Army Corps of Engineers \\
\hline Alan Veasey & Marine Corps Air Station Yuma \\
\hline Jennifer Whyte & BLM El Centro Field Office \\
\hline Marc Willis & NAF El Centro \\
\hline Lloyd Woosley, Jr. & USGS Reston, VA Office \\
\hline \multicolumn{2}{|c|}{ Native American tribes } \\
\hline \multirow[t]{8}{*}{ Patricia Tuck } & Agua Caliente Band of Cahuilla Indians \\
\hline & Ah-Mut-Pipa Foundation \\
\hline & AhaMakav Cultural Society \\
\hline & $\begin{array}{l}\text { Augustine Band of Cahuilla Mission } \\
\text { Indians }\end{array}$ \\
\hline & Barona Band of Diegueno Indians \\
\hline & Barona Band of Mission Indians \\
\hline & Cabazon Band of Mission Indians \\
\hline & Campo Kumeyaay Nation \\
\hline
\end{tabular}




\begin{tabular}{|c|c|}
\hline \multicolumn{2}{|c|}{ Cocopah Indian Tribe } \\
\hline & Colorado River Indian Tribes \\
\hline & Ewiiaapaayp Band of Kumeyaay Indians \\
\hline & Fort Yuma Quechan Tribe \\
\hline & Ft. Mojave Indian Tribe \\
\hline & Inaja-Cosmit Band of Mission Indians \\
\hline & Jamul Indian Village \\
\hline & Kwaaymii Laguna Band of Indians \\
\hline & La Jolla Band of Luiseno Indians \\
\hline & La Posta Band of Kumeyaay Indians \\
\hline & Los Coyotes Band of Indians \\
\hline & Manzanita Band of Kumeyaay Indians \\
\hline & Mesa Grande Band of Mission Indians \\
\hline & Morongo Band of Mission Indians \\
\hline & Pala Band of Mission Indians \\
\hline & $\begin{array}{l}\text { Pauma/Yuima Band of Luiseno Mission } \\
\text { Indians }\end{array}$ \\
\hline & Pechanga Band of Mission Indians \\
\hline & Quechan Indian Nation \\
\hline & Ramona Band of Mission Indians \\
\hline & Rincon Band of Luiseño Indians \\
\hline & San Luis Rey Band of Mission Indians \\
\hline & $\begin{array}{l}\text { San Manuel Band of Serrano Mission } \\
\text { Indians }\end{array}$ \\
\hline & San Pasqual Band of Diegueno Indians \\
\hline & Santa Rosa Band of Mission Indians \\
\hline & Santa Ysabel Band of Diegueno Indians \\
\hline & Sycuan Band of Kumeyaay Nation \\
\hline \multirow{4}{*}{$\begin{array}{l}\text { Lisa Milward Auclair, } \\
\text { Roland Ferrer, and Ben } \\
\text { Scoville }\end{array}$} & Torres-Martinez Desert Cahuilla Indians \\
\hline & $\begin{array}{l}\text { Twenty-Nine Palms Band of Mission } \\
\text { Indians }\end{array}$ \\
\hline & Viejas Band of Kumeyaay Indians \\
\hline & State organizations \\
\hline Javier Alonso & California Department of Transportation \\
\hline Brad Berger & $\begin{array}{l}\text { Burns Pinon Reserve and Copper } \\
\text { Mountain College }\end{array}$ \\
\hline William Bretz & UC Irvine Urban Water Research Center \\
\hline John Carmona & $\begin{array}{l}\text { California Regional Water Quality Control } \\
\text { Board, Colorado River Basin Region }\end{array}$ \\
\hline Jack Crayon & California Department of Fish and Game \\
\hline Bob Heflin & California Highway Patrol \\
\hline
\end{tabular}




\begin{tabular}{|c|c|}
\hline Bill Owen & California Department of Transportation \\
\hline Ike Oza & California Department of Transportation \\
\hline Trevor Pratt & $\begin{array}{l}\text { Office of Historic Preservation, California } \\
\text { Department of Parks and Recreation }\end{array}$ \\
\hline Gail Sevrens & California State Parks \\
\hline Doug Wylie & $\begin{array}{l}\text { California Regional Water Quality Control } \\
\text { Board, Colorado River Basin Region }\end{array}$ \\
\hline \multicolumn{2}{|c|}{ County organizations } \\
\hline Michelle Cano & $\begin{array}{l}\text { Riverside County Flood Control and } \\
\text { Conservation District }\end{array}$ \\
\hline Joan Carr & Imperial County Surveyor \\
\hline Laura Cervantes & Imperial County Assessor's Office \\
\hline Jack Cummings & Riverside County DOT \\
\hline Edde Estrada & Imperial County Fire Department \\
\hline Matthew Hickman & $\begin{array}{l}\text { Riverside County Waste Management } \\
\text { Department }\end{array}$ \\
\hline Robert Istik & $\begin{array}{l}\text { Riverside County Waste Management } \\
\text { Department }\end{array}$ \\
\hline Deputy Peter M. Lawson & Riverside County Sheriff's Department \\
\hline Ed Lotz & $\begin{array}{l}\text { Riverside County Flood Control and } \\
\text { Conservation District }\end{array}$ \\
\hline Tom Rheiner & $\begin{array}{l}\text { Riverside County Flood Control and } \\
\text { Conservation District }\end{array}$ \\
\hline Rosie Sampson & Imperial County Sheriff's Office \\
\hline Zully Smith & $\begin{array}{l}\text { Riverside County Flood Control and } \\
\text { Conservation District }\end{array}$ \\
\hline Mickey Zolezio & Riverside County Assessor's Office \\
\hline \multicolumn{2}{|c|}{ City/regional organizations } \\
\hline Jacob Alvarez & $\begin{array}{l}\text { Coachella Valley Association of } \\
\text { Governments }\end{array}$ \\
\hline Steve Bigley & Coachella Valley Water District \\
\hline Roland Bustamante & Coachella Valley Water District \\
\hline Patricia Casillas & Imperial Irrigation District \\
\hline Georgia Celehar-Bauer & Coachella Valley Water District \\
\hline Carlos Cueva & $\begin{array}{l}\text { Desert Alliance for Community } \\
\text { Empowerment }\end{array}$ \\
\hline R. Page Garner & City of Palm Desert \\
\hline Socrates Gonzalez & Imperial Irrigation District \\
\hline George Herrera & Palm Springs City Maintenance \\
\hline Tyler Hull & Coachella Valley Water District \\
\hline Jim Kelley & Imperial Irrigation District \\
\hline Kevin Marty & Imperial Valley College \\
\hline Juan Medina & Coachella Valley Water District \\
\hline Gary Rosenblum & City of Palm Desert \\
\hline
\end{tabular}




\begin{tabular}{|c|c|}
\hline Gilbert Ramirez & Coachella Valley Water District \\
\hline Ginny Short & Coachella Valley Preserve \\
\hline Shane Stueckle & Town Of Yucca Valley \\
\hline Jim Sullivan & $\begin{array}{l}\text { Coachella Valley Association of } \\
\text { Governments }\end{array}$ \\
\hline John Wohlmuth & City of Palm Desert \\
\hline \multicolumn{2}{|c|}{ Private companies } \\
\hline \multicolumn{2}{|l|}{ Colin Barrows } \\
\hline Mike Barth & Subsea Systems, Inc. \\
\hline Jerry Bell & The Living Desert \\
\hline Lisa Blewitt & Applied Earthworks \\
\hline Gordon Coleman & Alpha Explosives \\
\hline Jim Cross & Cross International \\
\hline Sam and Patricia Crum & Sam Crum Drilling \\
\hline Jim DeForge & Bighorn Institute \\
\hline Marie Giron & California Institute of Technology \\
\hline Melinda Horne & Applied Earthworks \\
\hline Alec Johnsen & Iberdrola \\
\hline Stacey Johnson & The Living Desert \\
\hline Simon Klemperer & Stanford University \\
\hline Summer Miller & California Institute of Technology \\
\hline Sean "Butch" Mederos & AES Wind Generation \\
\hline Donna Mireles & California Institute of Technology \\
\hline Mike Mirro & Applied Earthworks \\
\hline Rob Parkins & Palm Springs Aerial Tramway \\
\hline $\begin{array}{l}\text { Pyramid Construction and } \\
\text { Aggregates }\end{array}$ & Heber, California \\
\hline Deborah Rogers & Center for Natural Lands Management \\
\hline Alexander Schriener, Jr. & CalEnergy Operating Corporation \\
\hline Peter Siminski & The Living Desert \\
\hline Steve and Kelly Sixkiller & Sixkiller Drilling \\
\hline Jon Trujillo & CalEnergy Operating Corporation \\
\hline Donald Wagstaff & Mesquite Gold Mine (New Gold, Inc.) \\
\hline Jim Whitmore & Palm Springs Aerial Tramway \\
\hline Julia Zuckerman & California Institute of Technology \\
\hline
\end{tabular}

\section{References Cited}

Aragon-Arreola, M., and Martin-Barajas, A., 2007, Westward migration of extension in the northern Gulf of California, Mexico: Geology, v. 35, p. 571-574.

Axen, G.J., and Fletcher, J.M., 1998, Late Miocene-Pliocene extensional faulting, northern Gulf of California, Mexico, and Salton Trough, California: International Geology Review, v. 40, p. 219-244. 
Axen, G.J., Fletcher, J.M., Cowgill, E., Murphy, M., Kapp, P., MacMillan, I., RamosValazquez, E., and Aranda-Gomez, J., 1999, Range-front fault scarps of the Sierra El Mayor, Baja California-Formed above an active low-angle normal fault?:Geology, v. 27, p. 247-250.

Becker, J.J., Sandwell, D.T., Smith, W.H.F., Braud, J., Binder, B., Depner, J., Fabre, D., Factor, J., Ingalls, S., Kim, S.H., Ladner, R., Marks, K., Nelson, S., Pharaoh, A., Trimmer, R., Von Rosenberg, J., Wallace, G., and Weatherall, P., 2009, Global Bathymetry and Elevation Data at 30 Arc Seconds Resolution-SRTM30_PLUS: Marine Geodesy, v. 32, no. 4, p. 355-371.

Biehler, S., Kovach, R.W., and Allen, C.R., 1964, Geophysical framework of the northern gulf province, in van Andel, T.H., and Shor, Jr., G.G., eds., Marine Geology of the Gulf of California: American Association of Petroleum Geologists, v. 3, p. 126-143.

Brothers, D.S., Driscoll, N.W., Kent, G.M., Harding, A.J., Babcock, J.M., and Baskin, R.L., 2009, Tectonic evolution of the Salton Sea inferred from seismic reflection data: Nature Geoscience, v. 2, p. 581-584.

Dorsey, R.J., Fluette, A., McDougall, K., Housen, B.A., Janecke, S.U., Axen, G.J., and Shirvell, C.R., 2007, Chronology of Miocene-Pliocene deposits at Split Mountain Gorge, southern California: A record of regional tectonics and Colorado River evolution: Geology, v. 35, p. 57-60.

Dorsey, R.J., and Lazear, G.D., 2011, Erosional mass balance for a transtensional orogeny-Abstract EP41D-0638, in Meeting of the American Geophysical Union, San Francisco, Calif., December 5-9, 2011, Proceedings: San Francisco, Calif., American Geophysical Union.

Elders, W.A., Rex, R.W., Meidav, T., Robinson, P.T., and Biehler, S., 1972, Crustal spreading in southern California: Science, v. 178, p. 15-24.

Farr, T.G., Rosen, P.A., Caro, E., Crippen, R., Duren, R., Hensley, S., Kobrick, M., Paller, M., Rodrigues, E., Roth, L., Seal, D., Shaffer, S., Shimada, J., Umland, J., Werner, M., Oskin, M., Burbank, D., and Alsdorf, D., 2007, The shuttle radar topography mission: Reviews of Geophysics, v. 45, no. 2, doi:10.1029/2005RG000183, http://www2.jpl.nasa.gov/srtm/.

Fletcher, J.M., and Spelz, R.M., 2009, Patterns of Quaternary deformation and rupture propagation associated with an active low-angle normal fault, Laguna Salada, Mexico-Evidence of a rolling hinge?: Geosphere, v. 5, no. 4, p. 385-407.

Folk, M., and Pournal, E., 2010, Balancing performance and preservation lessons learned with HDF5: The HDF Group, accessed February 5, 2013 at http://www.hdfgroup.org/pubs/papers/.

Fuis, G.S., and Kohler, W.M., 1984, Crustal structure and tectonics of the Imperial Valley region, California, in Rigsby, C.A., ed., The Imperial Basin-Tectonics, sedimentation, and thermal aspects: Society of Economic Paleontologists and Mineralogists (SEPM), Pacific Section, p. 1-13.

Fuis, G. S., Mooney, W.D., Healy, J.H., McMechan, G.A., and Lutter, W.J., 1984, A seismic refraction survey of the Imperial Valley region, California: Journal of Geophysical Research, v. 89, p. 1,165-1,189.

Fuis, G.S., Murphy, J.M., Okaya, D.A., Clayton, R.W., Davis, P.M., Thygesen, K., Baher, S.A., Ryberg, T., Benthien, M.L., Simila, G., Perron, J.T., Yong, A.K., 
Reusser, L., Kaip, G., Fort, M.D., Asudeh, I., Sell, R., Vanschaack, J.R., Criley, E.E., Kaderabek, R., Kohler, W.M., Magnuski, N.H., 2001a, Report for borehole explosion data acquired in the 1999 Los Angeles Region Seismic Experiment (LARSE II), Southern California: Part I, Description of the survey: U.S.

Geological Survey Open-File Report 01-408, 82 p., http://geopubs.wr.usgs.gov/open-file/of01-408/.

Fuis, G.S., Ryberg, T., Godfrey, N.J., Okaya, D.A., and Murphy, J.M., 2001b, Crustal structure and tectonics from the Los Angeles basin to the Mojave Desert, southern California: Geology, v. 29, p. 15-18.

Fuis, G.S., Scheirer, D.S., Langenheim, V.E., and Kohler, M.D., 2012, A new perspective on the geometry of the San Andreas Fault in Southern California and its relationship to lithospheric structure: Bulletin of the Seismological Society of America, v. 102, p. 236-251.

Hardebeck, J.L., and Hauksson, E., 2001, Crustal stress field in southern California and its implications for fault mechanics: Journal of Geophysical Research, v. 106, no. 21, p. 21,859-21,882.

Hauksson, E., and Shearer, P., 2005, Southern California hypocenter relocation with waveform cross-correlation, Part 1-Results using the double-difference method: Bulletin of the Seismological Society of America, v. 95, p. 896-903.

Hauksson, E., Stock, J.M., Hutton, K., Yang, W., Vidal-Villegas, A., and Kanamori, H., 2011, The 2010 M (w) 7.2 El Mayor-Cucapah earthquake sequence, Baja California, Mexico and southernmost California, USA-Active seismotectonics along the Mexican Pacific Margin: Pure and Applied Geophysics, v. 168, no. 8-9, p. $1255-1277$.

Ichinose, G., Day, S., Magistrale, H., and Prush, T., 1996, Crustal thickness variations beneath the Peninsular Ranges, southern California: Geophysical Res. Letters, v. 23, p. 3,095-3,098.

Jones, L.M., Bernknopf, R., Cox, D., Goltz, J., Hudnut, K., Mileti, D., Perry, S., Ponti, D., Porter, K., Reichle, M., Seligson, H., Shoaf, K., Treiman, J., and Wein, A., 2008, The shakeout scenario: U.S. Geological Survey Open-File Report 2008-1150, California Geological Survey Preliminary Report 25, 308 p.

Kirby, S.M., Janecke, S.U., Dorsey, R.J., Housen, B.A., Langenheim, V.E., McDougall, K.A., and Steely, A.N., 2007, Pleistocene Brawley and Ocotillo FormationsEvidence for initial strike-slip deformation along the San Felipe and San Jacinto fault zones, southern California: Geology, v. 115, p. 43-62.

Kohler, W.M., and Fuis, G.S., 1986, Traveltime, time-term, and basement depth maps for the Imperial Valley region, California, from explosions: Bulletin of the Seismological Society of America, v. 76, p. 1,289-1,303.

Kohler, M.D., Magistrale, H., and Clayton, R.W., 2003, Mantle heterogeneities and the SCEC Reference Three-Dimensional Seismic Velocity Model Version 3: Bulletin of the Seismological Society of America, v. 93, p. 757-774.

Kovach, R.L., Allen, C.R., and Press, F., 1962, Geophysical investigations in the Colorado Delta region: Journal of Geophysical Research, v. 67, no. 7, p. 2,8452,871 . 
Lachenbruch, A.H., Sass, J.H., and Galanis, Jr., S.P., 1985, Heat flow in southernmost California and the origin of the Salton Trough: Journal of Geophysical Research, v. 90, p. 6,709-6,736.

Larkin, S.P., Levander, A., Okaya, D., and Goff, J.A., 1996, A deterministic and stochastic velocity model for Salton Trough-Basin and range transition zone and constraints on magmatism during rifting: Journal of Geophysical Research, v. 101, p. 27,883-27,897.

Lin, G., Shearer, P.M., and Hauksson, E., 2007, Applying a three-dimensional velocity model, waveform cross correlation, and cluster analysis to locate southern California seismicity from 1981 to 2005: Journal of Geophysical Research, v. 112, B12309, 14 p.

Lomnitz, C., Mooser, F., Allen, C.R., Brune, J.N., and Thatcher, W., 1970, Seismicity and tectonics of the northern Gulf of California region, Mexico-Preliminary results: Geofisica Internacional, v. 10, no. 2, p. 37-48.

Lonsdale, P., 1989, Geology and tectonic history of the Gulf of California, in Winterer, E.L., Hussong, D.M., and Decker, R.W., eds., The Eastern Pacific Ocean and Hawaii: Geological Society of America, Decade of North American Geology, v. N, p. 499-521.

Muffler, L.J.P., and Doe, B.R., 1968, Composition and mean age of detritus of the Colorado River delta in the Salton Trough, southeastern California, Journal of Sedimentary Petrology, v. 38, p. 384-399.

Murphy, J.M., Fuis, G.S., Ryberg, T., Okaya, D.A., Criley, E.E., Benthien, M.L., Alvarez, M., Asudeh, I., Kohler, W.M., Glassmoyer, G.N., Robertson, M.C., and Bhowmik, J., 1996, Report for explosion data acquired in the 1994 Los Angeles Region Seismic Experiment (LARSE94), Los Angeles, California: U.S. Geological Survey Open-File Report 96-536, 120 p., http://pubs.er.usgs.gov/publication/ofr96536.

Murphy, J.M, Goldman, M., Fuis, G.S., Rymer, M., Sickler, R., Miller, S., Butcher, L. A., Ricketts, J., Criley, C.J., Stock, J.M., Hole, J.A., and Chavez, G., 2010, Seismic calibration shots conducted in 2009 in the Imperial Valley, southern California, for the Salton Seismic Imaging Project (SSIP): U.S. Geological Survey Open-File Report 2010-1295, 79 p. and spreadsheet, http://pubs.usgs.gov/of/2010/1295/.

Oskin, M., Stock, J., and Martin-Barajas, A., 2001, Rapid localization of Pacific-North America plate boundary motion in the Gulf of California: Geology, v. 29, p. 459-462.

Oskin, M., and Stock, J., 2003, Miocene to recent Pacific-North America plate motion and opening of the Upper Delfin Basin, northern Gulf of California, Mexico: Geological Society of America Bulletin, v. 115, p. 1,173-1,190.

Parsons, T., and McCarthy, J., 1996, Crustal and upper mantle velocity structure of the Salton Trough, southeast California: Tectonics, v. 15, p. 456-471.

Perry, S, Cox, D., Jones, L., Bernknopf, R., Goltz, J., Hudnut, K., Mileti, D., Ponti, D., Porter, K., Reichle, M., Seligson, H., Shoaf, K., Treiman, J., and Wein, A., 2008, The shakeout earthquake scenario-A story that southern Californians are writing: U.S. Geological Survey Open-File Report 2008-1324, 16 p.

Robinson, P.T., Elders, W.A., and Muffler, L.J.P., 1976, Quaternary volcanism in Salton Sea geothermal field, Imperial Valley, California: Geological Society of America Bulletin, v. 87, p. 347-360. 
Rymer, M.J., Treiman, J.A., Kendrick, K.J., Lienkamper, J.J., Weldon, R.J., Bilham, R., Wei, M., Fielding, E.J., Hernandez, J.L., Olson, B.P.E., Irvine, P.J., Knepprath, N., Sickler, R.R., Tong, X., and Siem, M.E., 2011, Triggered surface slips in southern California associated with the 2010 El Mayor-Cucapah, Baja California, Mexico, earthquake: USGS Open-File Report 2010-1333, 62 p., http://pubs.usgs.gov/of/2010/1333/.

Schmitt, A.K. and Hulen, J.B., 2008, Buried rhyolites within the active, high-temperature Salton Sea geothermal system: Journal of Volcanology and Geothermal Research, v. 178, no. 4, p. 708-718.

Shearer, P.M., 2002, Parallel fault strands at 9-km depth resolved on the Imperial Fault, southern California: Geophysical Research Letters, v. 29, no. 14, doi: 2002GL015302, accessed February 5, 2013, at http://onlinelibrary.wiley.com/doi/10.1029/2002GL015302/abstract.

Shearer, P., Hauksson, E., and Lin, G., 2005, Southern California hypocenter relocation with waveform cross-correlation, Part 2-Results using source-specific station terms and cluster analysis: Bulletin of the Seismological Society of America, v. 95, p. 904-915.

Stock, J.M., 2000, Relation of the Puertecitos Volcanic Province, Baja California, Mexico, to development of the plate boundary in the Gulf of California, in Delgado-Granados, H., Aguirre-Diaz, G., and Stock, J.M., eds., Cenozoic tectonics and volcanism of Mexico: Geological Society of America Special Paper, v. 334, p. 143-156.

Stock, J.M., and Hodges, K.V., 1989, Pre-Pliocene extension around the Gulf of California and the transfer of Baja California to the Pacific plate: Tectonics, v. 8, p. 99-115.

Tanimoto, T., and Sheldrake, K.P., 2002, Three-dimension S-wave velocity structure in southern California: Geophysical Research Letters, v. 29, doi: 2001GL013486, accessed February 5, 2013 at http://onlinelibrary.wiley.com/doi/10.1029/2001GL013486/abstract.

Wessel, P., and Smith, W.H.F., 1991, Free software helps map and display data: Eos, Transactions American Geophysical Union, v. 72, p. 441.

Winker, C.D., and Kidwell, S.M., 1986, Paleocurrent evidence for lateral displacement of the Pliocene Colorado River delta by the San Andreas Fault system: Geology, v. 14, p. 788-791.

Yang, Y., and Forsyth, D.W., 2006, Rayleigh wave phase velocities, small-scale convection, and azimuthal anisotropy beneath southern California: Journal of Geophysical Research, v. 111, doi: 2005JB004180, accessed February 5, 2013 at http://onlinelibrary.wiley.com/doi/10.1029/2005JB004180/abstract.

Zhao, D., Kanamori, H., and Humphreys, E., 1996, Simultaneous inversion of local and teleseismic data for the crust and mantle structure of southern California: Physics of the Earth and Planetary Interiors, v. 93, p. 191-214. 


\section{Appendixes}

Appendix files are available for download at http://pubs.usgs.gov/of/2013/1172/.

Appendix I. Drill logs

Appendix II. Drill sample inventory

Appendix III. Land seismometer locations

Appendix IV. OBS locations

Appendix V. Air gun shot times and locations (complete list)

Appendix VI. Data supplied to PIs by IRIS

Appendix VII. SSIP KMZ files (for use in Google Earth'M)

Appendix VIII. Full datasets for tables 1-10 